\title{
CTENOHIOTS
}

$$
\text { c) } \ldots \pi
$$

\section{ATLANTIC COAST OF NORTH AMERICA}

ALFRED GOLDSBOROUGH MAYER 


\section{To Dr. Henry B. Bigehw} with the kind reganch of

$$
\text { aefued go nayger }
$$

Marine Biological Laboratory Library Woods Hole, Massachusetts

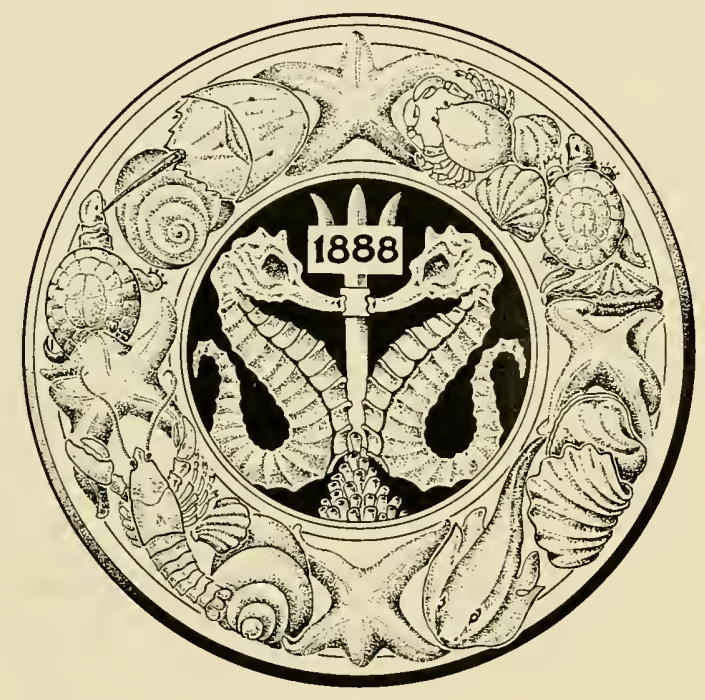








\section{CTENOPHORES}

OF THE

\section{ATLANTIC COAST OF NORTH AMERICA}

BY

ALFRED GOLDSBOROUGH MAYER

Director of the Department of Marine Biology, Carnegie Institution of Washington
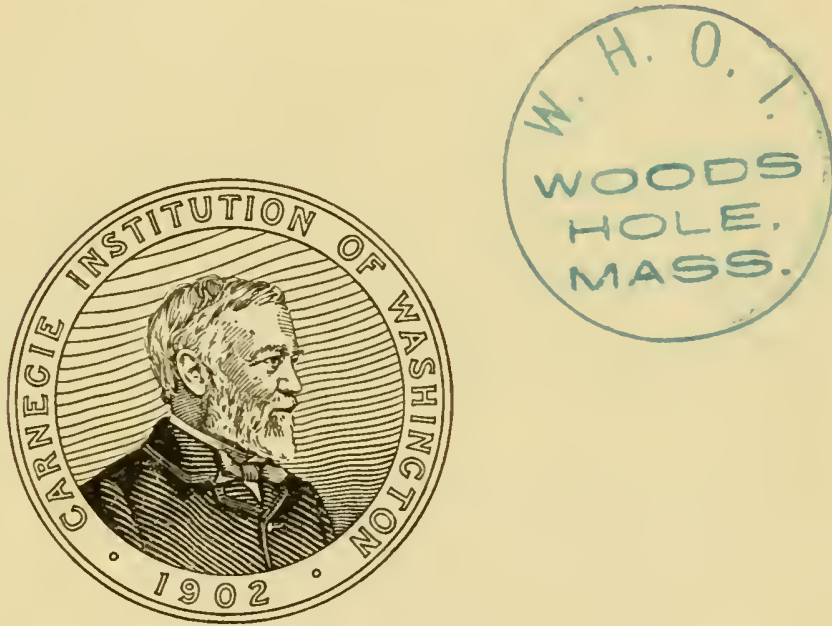

WASHINGTON, D. C.

Published by the Carnegie Institution of Washington 


\title{
CARNEGIE INSTITUTION OF WASHINGTON
}

Publication No. i62

\author{
Copian of tivis bone \\ ware frrst hajer \\ MAP $=1512$
}

PRESS OF J. B. LIPPINCOTT COMPANY

PHILADELPHIA, PA. 


\title{
CTENOPHORES OF THE ATLANTIC COAST OF NORTH AMERICA.
}

\author{
By Alfred Goldsborough Mayer.
}

This research was begun in 1892 at the suggestion of Prof. Alexander Agassiz, while I was a student in his excellently equipped marine laboratory at Newport, Rhode Island. Until I 900 Professor Agassiz did all in his power to encourage these studies, and I now publish the final results in the hope that by so doing I may present them as a tribute of respect and gratitude to the memory of Alexander Agassiz to whose generous aid and unselfish interest so many young men have owed their impetus toward research in science.

It is a pleasure to express my appreciation of the kindness of the Honorable Mr. A. W. Piccott, Minister of Marine and Fisheries of Newfoundland, who cordially extended toward me every personal and official courtesy while I was engaged in the study of the ctenophores of the Newfoundland coast in September, r 9 ro.

During the past seven years at the Tortugas Laboratory of the Carnegie Institution of Washington it has been my custom to go out upon the ocean during periods of tropical calm, when the surface is unrippled, and to dip up the Ctenophores in glass vessels and transfer them to the laboratory for study. All but three of the species of Ctenophoræ described from American North Atlantic waters have come under my observation, and descriptions of these three, Lesueuria hyboptera, Ocyropsis maculata, and Tjalfiella tristoma are introduced in order to present an account of all ctenophoræ known from the Atlantic coast of North America. The species herein described are as follows:

SPECIES,

Mertensia ovum.....................................

Pleurobrachia pileus.............. North of Cape Cod in summer, driven southward in winter.

brunnea sp. nov...... Coast of New Jersey.

Hormiphora plumosa............... Mediterranean and tropical Atlantic.

Tinerfe lactea sp. nov............. Tortugas, Florida

beehleri sp. nov............... Tortugas, Florida.

Lesueuria hyboptera (problematical). Coast of Massachusetts north of Cape Cod.

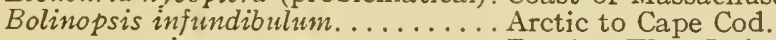

vitrea............... Tropics, West Indies, Florida, Mediterranean.

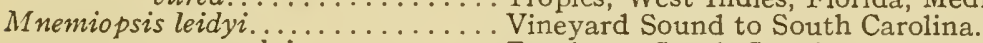
mccradyi........... Tropics to South Carolina.

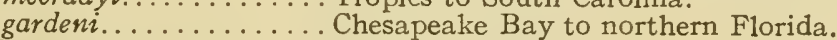

Leucothea ochracea sp. nov......... Tortugas, Florida.

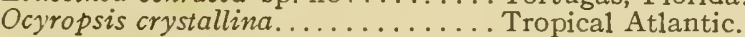

maculata............. Tropical Atlantic and Pacific.

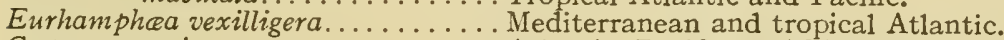

Cestum veneris................ Atlantic, Pacific, and Mediterranean.

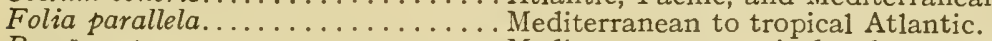

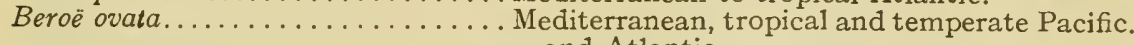
and Atlantic.

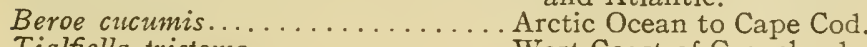

Tjalfiella tristoma..............West Coast of Greenland. 
It will be seen that there are 2 I ctenophores known from the Atlantic coast of North America. Of these, 6 are cold-water forms and do not commonly range southward of New Jersey along our coast, although Arctic forms are sometimes driven, by winter storms, as far south as Cape Hatteras; 3 are intermediate and are found between the southern shore of Cape Cod and northern Florida; I 2 are tropical species, some of which drift northward in summer to the region of Vineyard Sound. Thus, along this whole stretch of coast, extending from the Arctic regions to the tropics, we find only 2 I species, while Chun records 20 from the Mediterranean.

In no part of the North American coast are ctenophores as plentiful or as numerous in species as in the Bay of Naples, where I7 kinds were found by Chun. In contrast to this, the Tortugas region, which is richer in number of species than any other part of the North American coast, has but I 2 kinds of ctenophores. In the tropics, however, one does not often see the great swarms of one or a few species which are so commonly met with in the cold or Arctic waters. At Newport, Rhode Island, the surface of the sea is sometimes covered for thousands of square yards with great submerged rafts of Mnemiopsis leidyi, the individuals touching one the other, and the same phenomenon occurs with Pleurobrachia pileus or Bolinopsis infundibulum off the coast of northern Maine. At Tortugas, Florida, on the contrary, dense swarms of ctenophores are not seen, although more than twice as many species are found in this tropical region than off the coast of Maine.

Of the $2 \mathrm{I}$ forms described in this paper, 4 are new to science and 7 have not hitherto been recorded with certainty from the American coast; 6 are Mediterranean species which extend across the tropical Atlantic to the American coast. It is also of interest to see that 3 species, Pleurobrachia brunnea, Mnemiopsis leidyi, and $M$. gardeni are animals of the temperate regions, never having been taken in Arctic or in tropical waters.

A list of all of the then-known species of ctenophores with an account of their geographical ranges is given by Moser, I909, in Ctenophoren der deutsch. Südpolar-Expedition, Bd. I I, Zool. 3, p. I23. This important paper also gives a very complete list of references to literature upon ctenophores.

It is unfortunate that the old and time-honored generic names Bolina, Eucharis, Ocyroë, and Vexillum have been preoccupied and can not be retained for Ctenophoræ, and the names Bolinopsis, Leucothea, Ocyropsis, and Folia are suggested to replace them. Much as I regret the change, if the rules demand it we should make it at once.

As is well known, the Ctenophoræ are biradially symmetrical animals with a slit-like mouth at one pole, and at the opposite end of the body an apical sense-organ consisting of a mass of lithocysts said to be composed of phosphate of lime, and inclosed in a capsule the walls of which are probably formed of fused cilia, the mass of lithocysts being supported upon 4 flat triangular plates composed of fused cilia. On both sides of the apical sense-organ there is a long, narrow, elevated ridge of epithelial cells which are probably sensory and constitute the pole-plate.

The mouth, which is at the opposite end of the body, is a long narrow slit and leads into a laterally compressed chamber, the wide axis of which 
is in the plane of the pole-plate, while its narrow axis is in the plane of the tentacles when these are present. This buccal chamber is commonly called the "stomach," but its walls are of ectoderm and bear cilia, which are especially well developed in the Beroïæ, where they occur in linear, longitudinal areas extending from the lips inward. This chamber is certainly a food receptacle, and we will call it the stomodæum.

The stomodæum leads into the entodermal part of the gastric cavity, a laterally compressed chamber called the funnel or infundibulum. The wide axis of the funnel is perpendicular to that of the stomodæum and it lies in the plane of the two tentacles to the basal-bulb of each of which it sends a canal. It also sends a canal upward to the sense-organ, and this axial vessel, which is called the funnel-tube, opens by a pair of excretory pores on two diagonally opposite sides of the pole-plate. In the Beroïæ there are two lateral funnel-tubes, one to each excretory pore.

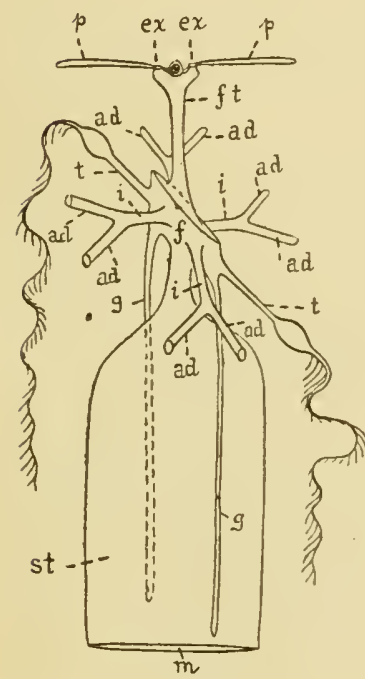

1.

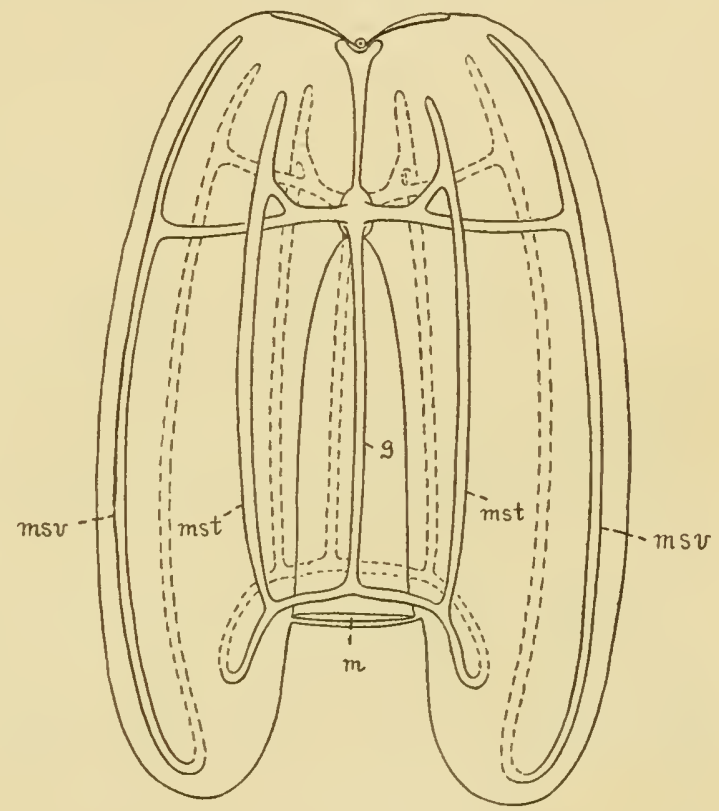

2.

Fıg. 1.-Diagram illustrating characters of central part of gastro-vascular system of ctenophores.

FIG. 2.-Diagram showing character of canal-circuits in Lobatc. Tentacles, tentacular canals, ciliary combs, and auricles are omitted.

In addition to the two tentacular vessels and the axial funnel-tube, the funnel gives rise to four interradial vessels, which arise typically at an angle of $45^{\circ}$ with the stomodæal and funnel axes. In the Cydippidæ, however, the four interradial vessels do not arise directly from the funnel, but the funnel-chamber gives rise to a pair of side tubes called the perradial vessels, pr, figs. 4 and 5 , pages II and $\mathrm{r} 2$, from the sides of which the four interradial canals arise. In any event the four interradial canals soon bifurcate and each of their eight adradial branches leads to a row of 
ciliary combs beneath and along the line of which there extends a meridional longitudinal vessel.

Two other vessels, the paragastric canals, arise from the funnelcavity in the tentacular plane and extend downward close to and along the middle of the broad sides of the stomodæum.

As this canal-system is complex I have sought to make its arrangement clear by presenting a diagram in figure $I$, which should be considered seriously only in so far as it is diagrammatic, and should be compared with figs. 4 and 5 , which illustrate the conditions seen in Pleurobrachia pileus. This diagram attempts to show a perspective view of the gastro-vascular cavity. The mouth, $m$, leads into the laterally flattened, slit-like cavity of the stomodæum, st; this in turn leads into the laterally flattened infundibulum or funnel, $f$, the flat side of which is $90^{\circ}$ a part from the flat side of the stomodæum. The axial funnel-tube, $f t$, leads upward from the funnel to open to the outside through the excretory pores, $e x$. The long, narrow ridge of the pole-plate, $p$, lies in the same plane as the stomodxum and $90^{\circ}$ apart from the axis through the funnel and tentacles. The funnel, $f$, gives rise to two tentacular canals, $t$, two paragastric canals, $g$, and four interradial canals, $i$. The four interradial canals bifurcate and give rise to eight adradial branches, ad, which lead to the meridional canals, which are not shown in this figure, but which extend along under the combs of cilia.

In the Cydippidæ the eight meridional canals and the two paragastric vessels end blindly near the oral end of the body, but in the higher ctenophores of the orders Ganeshidæ, Lobatæ, Cestidæ, and Beroïdæ their oral ends fuse in various ways, forming more or less complete circuits. Stages in the development of these fusions are shown in fig. 39 , plate 6 , and figs. 16 and 18 , plate 5 , and the completed circuits are clearly shown in fig. 56 , plate 10, which illustrates the condition in Ocyropsis wherein there are neither tentacles nor tentacular canals to complicate the figure.

Figure 2 is a diagram intended to make clear the plan of these fusions between the meridional and paragastric canals in the Lobatæ. For the sake of clarity I have left out the auricles, which are four ribbon-like expansions of the body on the tentacular sides of the mouth, and around the narrow edge of each of which the meridional, subtentacular vessels extend. The tentacles and tentacular canals are also omitted in this diagram. Vessels on the opposite side of the animal are dotted. The diagram shows how the two paragastric canals, $g$, fork at their oral ends and form a ring-canal surrounding the mouth, $m$, and the four meridional subtentacular canals fuse with this ring-canal. The four meridional subventral canals, $m s v$, which extend along the outer sides of the oral lobes fuse in pairs to form two loop circuits in the lobes, one loop in each lobe. This diagram applies only to the Lobatæ.

In the Cestidæ, on the other hand, the oral forks of the paragastric canal of each side of the body unite with the two subtentacular and subventral meridional vessels of that side only. Thus in this order there is no ring-canal around the mouth. This statement applies also to the young of the Beroidæ, although later the meridional vessels of both sides become connected by anastomosing side branches which appear quite 
late in ontogeny and grow outward from the sides of the 8 meridional canals and may anastomose, thus producing a network connecting all 8 of the canals, and forming a complex circum-oral canal-system. This remarkable similarity in respect to their canal-systems, together with their marked compression in the funnel-axis, may, I think, be taken as an indication that the Beroidæ and Cestidæ are related and derived from a common stock. The condition exhibited by the fusion of the paragastric and meridional systems of canals in the young Beroidæ and in mature Cestidæ is shown in fig. 3 , the lettering being similar in purport to that of fig. 2 .

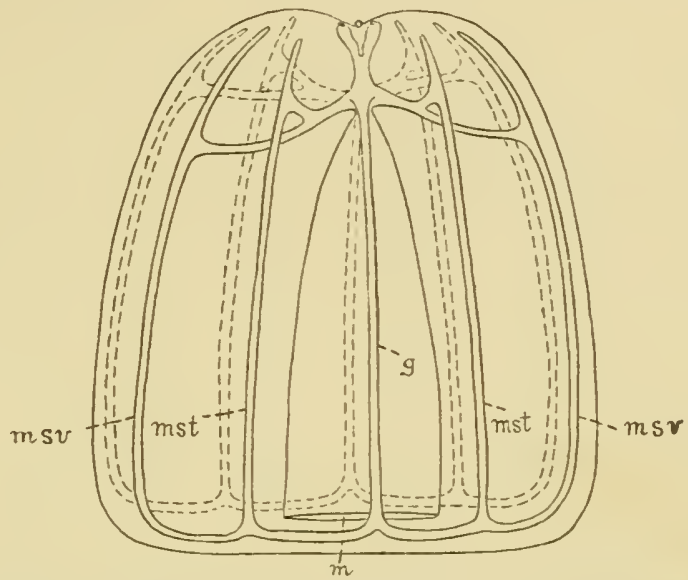

FIG. 3.-Diagram showing character of canal system in mature Cestidæ and young Beroïdx. In the Beroidæ the meridional and oral canals finally give off side branches which may anastomose, and form circumoral connectives, but these branches are not shown in the figure.

We may classify the Ctenophoræ in six orders as follows:

I. CYDIPPIDE: Body spherical or cylindrical, or widest in the tentacular diameter. Two long tentacles with or without side branches. The tentacles arise from pit-like depressions in the sides of the body, which constitute sheaths into which the tentacles may be withdrawn. The meridional and paragastric vessels do not fuse, but end blindly. No oral lobes, and no auricles.

II. Ganeshide: Moser, I907, Zool. Anzeiger, Bd. 31, p. 788; also, r908, Revue Suisse de Zool., tome i6, p. I 2.

Body compressed in the tentacular axis. The oral forks of the 2 paragastric canals form a complete (?) ring-canal around the mouth, and the 8 ineridional canals join this ring-canal. The interradial and tentacular canals arise directly from the funnel. A tentacle-sheath is present. There are no oral lobes and no auricles. The only known form is Ganesha elegans Moser, from the Malay Archipelago.

This remarkable order appears to be intermediate in its general character between the Cydippidæ and Lobatæ, but the fusion between the meridional canals and the oral forks of the paragastric vessels recalls the condition seen in Cestidæ and Beroidæ. The Cestidæ, however, lack a circumoral ring-canal, such as appears to exist in Ganesha.

III. Lоват : With 2 oral lobes in the stomodæal axis and 4 ribbon-like projections (auricles), 2 from each tentacular side of the body above the mouth. Body compressed in the funnel (tentacular) axis. The 4 subtentacular meridional canals fuse with the ring-canal which the oral forks of the 2 paragastric canals form around the mouth. The 4 subventral meridional canals fuse in pairs to form loops through the oral lobes, each canal being connected with its fellow of the opposite side of the same oral 
lobe. There are numerous, simple tentacles which extend along the wide sides of the mouth, and in the middle of each line there is usually a principal tentacle, which is commonly feathered and arises from a large projecting basal-bulb without a sheath. In Ocyropsis, however, there are neither tentacles nor tentacular canals. The subventral rows of combs are longer than the subtentacular. The larvæ pass through a stage in which they resemble the Cydippidæ, from which the Lobatæ are evidently descended. In the larva the tentacular axis is wider than the stomodæal axis, as in Cydippidæ, whereas the reverse is the case in the adult Lobatæ.

IV. CESTIDA: The lateral compression seen in the Lobatæ is greatly accentuated in this order, so that the body is flat and ribbon-like, the long side being in the stomodæal axis and the compression being in the funnel-axis. There is no ring-canal around the mouth, but the subventral and subtentacular vessels unite with the oral forks of the paragastric canals and the canal-systems of the two sides are separated, uniting only at the funnel. There is a row of tentacles along the oral forks of the paragastric vessels. The 2 median tentacles are the largest and are set within basal sheaths. The Cestidæ are closely related to Lobatæ, and their larvæ pass through a cydippe-stage as do the larvæ of the Lobatæ.

V. BEROİD $A$ : Lateral compression as in the Lobatæ and Cestidæ, the compression of the funnel-axis being generally more marked than in the Lobatæ, but not so pronounced as in the Cestidæ. Canal-system as in the Cestidæ, with the added feature that the meridional canals and the oral forks of the paragastric canals give off side branches which may anastomose and form a network connecting some or all of the vessels, in some species forming a circumoral canal-system. The axial funnel-canal is absent and is replaced by two side branches which extend upward from the funnel to the excretory pores. There are no tentacles even in the larva, which in other respects resembles the Cydippidæ. The stomodæum is very wide in the sagittal plane and constitutes a great sac, so that the funnel is very short.

VI. Platyctenide: Creeping or sessile, degenerate ctenophores, with the oralaboral axis much shortened, so that the oral and aboral sides of the animal are flat and expanded. With 2 tentacles, which in some forms may be withdrawn within sheaths. The apical sense-organ may be present, but in some forms the combs of cilia are absent. There are 3 genera, Tjalfiella Mortensen, Coloplana Kowalevsky and Ctenoplana Korotneff. The species occur in the Red Sea, Malay Region, Japan, and Greenland, and the most recent descriptions are by Willey, I897, Quarterly Journal Microscop. Sci., vol. 39, p. $3^{2} 3$; Abbott, I 902, Annot. Zool. Japonensis, vol. 4, p. I03; and Mortensen, I9 Io, Vid. Meddel. Foren. Kobenhavn, p. 249.

In the extreme tenuity of their bodily substance and their diaphanous delicacy of coloration, the ctenophores stand apart from other marine animals. Their presence in the water is commoniy denoted only by the brilliant flash of rainbow colors which play along the lines of their ciliary combs as they move languidly beneath the unrippled surface of the sea. Yet these creatures are no more wonderful in their complex organization than in their remarkable adjustment to their habitat, for so delicate are most of them that a current such as that of an oar suffices to tear them into misshapen shreds-a fate which they escape in time of storm by sinking far into the depths. This fact accounts for the extreme rarity of many of these forms, for the ocean's surface must have remained flat as a mirror for many hours before they can be lured upward from the calm of their deep retreat. Yet tender as they are to the touch, passing jelly-like between the fingers of the hand that attempts to seize them, their food consists largely of young fishes which they engulf in great numbers, seizing their prey by means of their peculiar "Greifzellen" (see Chun, I880, Ctenophoren des Golfes von Neapel, p. 225, Taf. I8). Thus in the cold northern waters where ctenophores occur in vast swarms, 
they constitute a serious menace to the cod fisheries by devouring the pelagic eggs and young fish.

The elucidation of the minute anatomy of ctenophores has been one of the greatest triumphs of modern histology, and one with which one associates the names of Fol, Chun, R. Hertwig, Samassa, Grabe, and Bethe.

Samassa was unable to demonstrate the existence of a nervous system in Ctenophores, but Bethe, I895 (Biol. Centralblatt, Bd. I 5, p. I 40), placed living $C y d i p p e$ in a solution of I in 4,000 of methylen blue in seawater, and upon sectioning the $C y d i p p e$ he claims to have found a subepithelial network of nervous nature. This consists of large, ganglionic cells scattered at fairly regular intervals. Each of these cells gives rise to 3 or 4 protoplasmic processes which fuse with like processes from other ganglia, thus appearing to form a nervous network without separate neurons; a condition so extraordinary that confirmatory studies must be made before we can accept it as proven.

The experiments of Parker upon Mnemiopsis lend support to the conclusion that nervous elements may extend outward from the apical sense-organ along under the combs of cilia, or at any rate the normal rhythm of the ciliary combs is controlled by the nervous or muscular elements. I now find that in ctenophores when the muscles contract the cilia cease to beat, being inhibited by the stretching of the ciliated epithelium. A solution of 0.4 molecular $\mathrm{MgCl}_{2}$, which inhibits muscular movement and produces relaxation, causes an incessant and very active movement of the cilia, but coördinated movements of the rows of combs are usually destroyed, each comb beating independently of its neighbors and at an exceedingly rapid rate, uncontrolled by the nervous system. In $M$. mccradyi, however, coördination is retained.

From the physiological side there is evidence, but no proof, to support the view that there is in ctenophores a nervous system comparable to that seen in higher metazoa. The results of such physiological researches are stated in this paper under Nmemiopsis and Berö̈. Recently Bauer, I9ro, Zeitschrift für Allgemeine Physiol., Jena, Bd. ro, p. 23I; concludes that the combs of ctenophores are under the control of a nervous system. He states that the nervous system can produce an acceleration or a retardation of the movements of the combs. Weak mechanical stimuli such as touching the mouth-region cause a stopping of the combs, while strong stimuli cause an acceleration. The sensory pole is without significance for this reflex. A summation of weak stimuli produces finally the effect of a single strong stimulus, and thus ctenophores show the well-known "treppe" effect which has been observed in higher forms. 


\section{Order CYDIPPIDE Gegenbaur, 1856.}

Cydippidce, Gegenbaur, I856, Archiv für Naturgesch., Jahrg. 22, p. I96.-Chun, I 880, Ctenophoren des Golfes von Neapel, Pp. 30, 273, 275.-MOSER, 1903, Ctenophoren der Siboga-Expedition, p. 4.-VANHÖFFEN, I906, Nordisches

Plankton, Ctenophoren, xi, p. 2.

Pleurobrachiida, Ghigi, I909, Ctenofori, Firenze, vol. 2, fasc, I, p. 7.

\section{CHARACTERS OF THE CYDIPPIDE.}

Ctenophoræ with 2 tentacles in the funnel diameter which arise from sheath-like clefts in the sides of the body. The body is usually laterally compressed, the tentacular diameter being the wider, although it may be spherical or cylindrical. There are neither oral lobes nor auricles. The meridional and paragastric canals end blindly. The tentacles may be simple or with side branches. The axis of the tentacle is mesodermal as in other ctenophores.

\section{Genus MERTENSIA Lesson, 1836 .}

Mertensia, Lesson, i 836 , Annals des Sci. Nat., sér. 2, tome 5 , p. 253 ; 1843 , Hist. Zooph. Acal., p. Ioo.-Mörch, I857, Nat. Bid. til en Beskriv. af Grönland, p. 97.-Agassiz, A., I 865 , North Amer. Acal., p. 26.-Chun, I898, Ergeb. der Plankton-Expedition, Ctenophoren, p. ro.-VANHöfFEN, r9o6, Nordisches Plankton, II, Ctenophoren, p. 2.-MOSER, I909, Ctenophoren der deutsch. Südpolar-Exped., Bd. Ir, Zool. 3, p. I23.

\section{GENERIC CHARACTERS.}

Cydippidæ in which the body is laterally compressed, the tentacular axis being wider than the axis through the plane of the stomodæum. The 4 subtentacular rows of cilia are longer than the 4 subventral rows and arise at a higher level, and are farther removed from the apical senseorgan than the latter. There are no wing-like protuberances upon the sensory pole-plate.

The type species is Mertensia ovum of the Arctic Ocean. It was first described by Fabricius, I780, as Beroë oun

Mertensia ovum Lesson. (Fig. I, plate I.)

Beroë ovum, FABRicius, I 780 , Fauna Grönlandica, p. 362 , No. 355 .

Cydippe ovum, C. cucullus, Eschscholtz, I829, Syst. der Acal., p. 25.

Beroë pileus, Scoresby, I 820, Arct. Reg., 2, plate r6, fig. 4.

Mertensia ovum, Lesson, I836, Annales des Sci. Nat., sér. 2, tome 5, p. 254.

Cydippe (Mertensia) ovum, Mö RCH, I857, Beskriv. af Grönland, p. 97.

Mertensia scoresbyi, Lesson, I 843, Hist. Zooph. Acal., p. Ioo.

Cydippe cucumis, Lesson, I 843 , Hist. Zooph. Acal., p. Io5.

Mertensia cucullus, Agassiz, L., i 860 , Cont. Nat. Hist. U. S., vol. 3, p. 293.

Mertensia ovum, Agassiz, A., I865, North Amer. Acalephæ, p. 26, figs. 29 to 37 ; I 874 , Mem. American Acad., vol. Io, No. 3, p. 375 , figs. I, 2.-VANHöfFEN, I 895 , Bibliotheca Zoologica, Heft 20, Lfg. I, p. 2 I. -Chun, I 898 , Ctenophoren der Plankton-Expedition, p. Io-Römer, I 903, Fauna Arctica, Ctenophoren, Bd. 3, p. 72 (full list of literature). -VANHÖfFEN, I906, Nordisches Plankton, xi, Ctenophoren, p. 2, figs. I to 3.-BIgelow, I909, Proc. U. S. Nat. Mus., Washington, vol. 37, p. 3 I6.

M. ovum is larger than Pleurobrachia pileus, becoming $55 \mathrm{~mm}$. long. Body egg-shaped in outline, the mouth being at the pointed pole and the apical sense-organ at the broad end. The body is strongly compressed in the plane perpendicular to the tentacular radii, and thus the creature superficially resembles a much-flattened Pleurobrachia. The apical sense-organ contains a mass of small concretions and is surrounded by a 



\section{Plate I.}

Fig. I. Mertensia ovum, immature. Agassiz Laboratory, Newport, Rhode Island, September 7, I895.

Fig. 2. Pleurobrachia brunnea sp. nov., mature. In the ocean 5 miles off Barnegat Bay, New Jersey, October I6, I904.

FIG. 3. Pleurobrachia brunnea. Side view of apical sense-organ.

FIG. 4. Pleurobrachia brunnea. View of one of the side branches of the tentacles.

Drawn from life, by the author. 

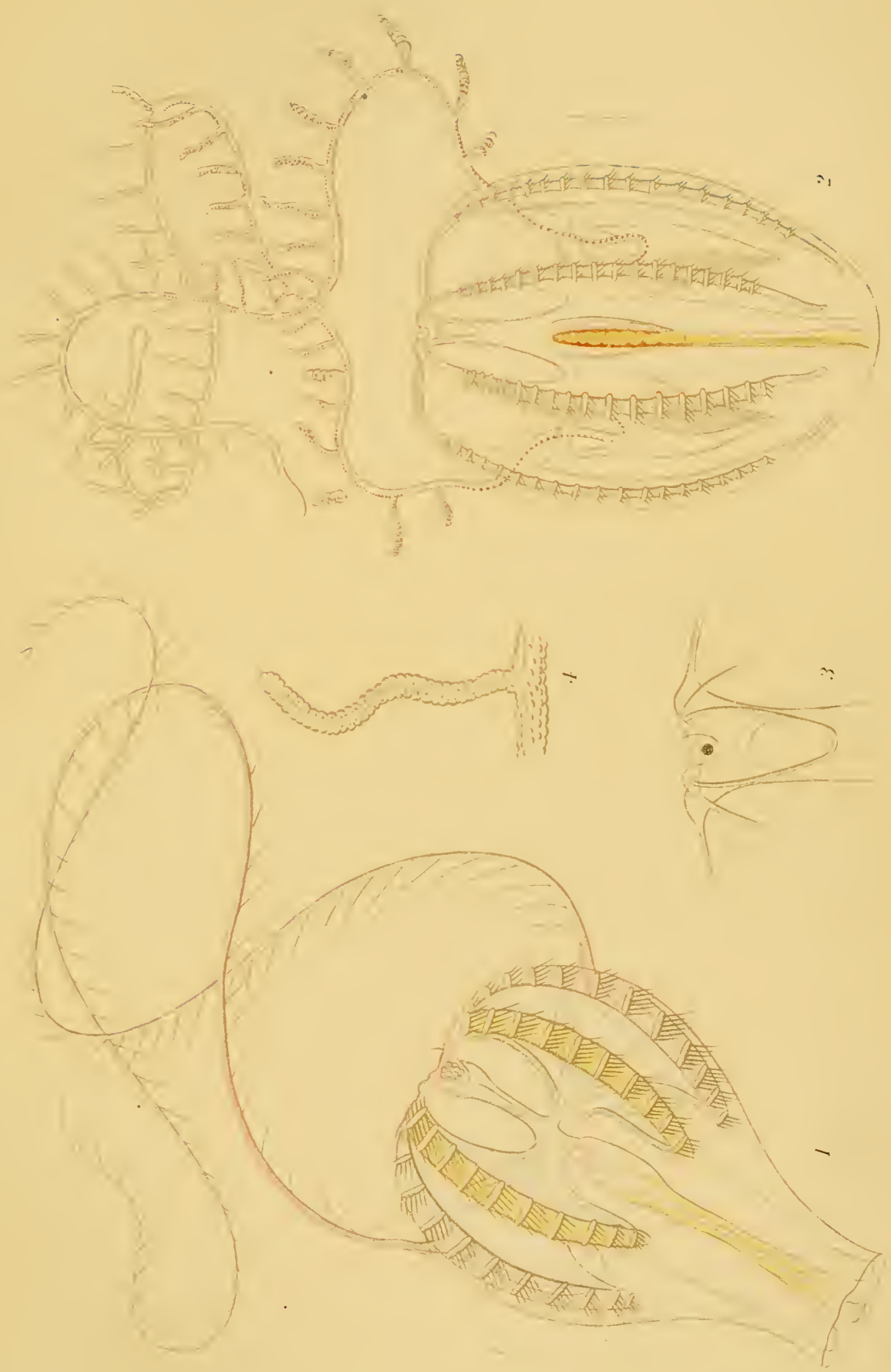

smooth-edged polar plate, there being no wing-like protuberances, such as are seen in Beroé. The 4 subtentacular rows of cilia are longer than the 4 subventral rows and extend fully four-fifths the distance from the apical plate to the oral end of the animal. The tentacles are long and contractile and give rise to numerous short, simple, lateral branches. The tentacles, rows of cilia, and pole-plate are light pink in color, while the genital products are of a decided shade of the same color; the male products being more brilliant than the female.

When very young the body is almost spherical, the oral end, however, being bluntly pointed. The rows of cilia are more fully developed than in the young Pleurobrachia of the same age, while the tentacles are relatively smaller and less developed and acquire their lateral branches later. In the young Mertensia, also, there are prominent orange pigment cells along the rows of cilia, and these are not found in Pleurobrachia.

This species is found in the Arctic Ocean. It extends southward in winter to the New Jersey coast, becoming rarer towards the south. Young individuals are occasionally found during the summer months in Newport Harbor, Rhode Island, but the adults have never been taken south of Massachusetts Bay. It is sometimes seen in great numbers in the harbor of Eastport, Maine, in September, but its true home is off the Labrador coast. Chun, 1898 , reports that large numbers of this ctenophore were observed by the Plankton Expedition in the Labrador stream, and says that it is identical with the Beroe octoptera described by Mertens, I 833 (Mém. Acad. Nat. Sci. St. Pétersbourg, sér. 6, tome 2, p. 528), from Behring Sea.

Bigelow finds that Mertensia ovum from the coast of Labrador feeds upon the sculpin.

\section{Genus PLEUROBRACHIA Fleming, 1822.}

Pleurobrachia, Fleming, I822, Philos. of Zool., vol. 2, p. 6I 2; also, Hist. British Animals, I828, p. 504.-AGassiz, L., 1849, Mem. American Acad., vol. 4, p. 314; also I 860, Cont. Nat. Hist. U.S., vol. 3, p. 203.-Agassiz, A., I865, North Amer. Acalephæ, p. 29.-CHUN, I 880, Ctenophoren des Golfes von Neapel, p. 281.-CHUN, I898, Ctenophoren der Plankton-Expedition, p. I 5-VANHÖFFEN, I906. Nordisches Plankton, Ctenophoren, p. 3.-MoseR, I903, Ctenophoren der Siboga-Expedition, pp. 5, 30; r909, Ctenophoren der deutsche Südpolar-Exped., Bd. I I, Zool. 3, p. I 4 I.

Cydippe, Eschschoztz, I829, Syst. der Acal., p. 29.-Lesson, I843, Hist. Zooph. Acal., p. 104.

\section{GENERIC CHARACTERS.}

Cydippidæ with an egg-shaped body with but little lateral compression, the tentacular diameter being only slightly wider than the sagittal. In this respect Pleurobrachia differs markedly from Mertensia, wherein the sagittal diameter is much narrower than the tentacular. The tentacle bulbs are placed within deep clefts, midway between the sides of the stomach and the general surface of the body. The 2 long, lateral tentacles give rise to numerous, simple, filamentous side branches. The 8 meridional canals extend under and along the 8 rows of cilia and end blindly, not forming a closed system of tubes.

The type species is Pleurobrachia pileus of the colder waters of the Atlantic, being abundant off the northern coast of Europe and America.

Moser, 1903, gives a description of all of the so-called species, and in 1909 she presents a very complete list of references to literature and an account of the geographical range of all species. 
Pleurobrachia pileus Vanhöffen.

Beroe pileus, Fabricius, I 780 , Fauna Grönlandica, p. 36r, Nr. 354 .

Beroë globigereux, Cuvier, I8 I 7, Règne Animal, tome 4, p. 59.

Cydippe pileus, Gould, I84 I, Report Invert. Mass., p. 349.-Mठ Rch, O., I857, Beskriv. af Grönland, p. 97.

Pleurobrachia rhododactyla, ÁgAsiz, L., I 849, Mem. American Acad., vol. 4, part Io, p. 3 I 4 , plates I to 5 ; ibid., I 860 , Cont. Nat. Hist. U. S., vol. 3, pp. 203 . 294; plate 2a.-Strmpson, W., I 853, Marine Invert. Grand Manan, p. i r.Agassiz, A., I865, North Amer. Acal., p. 30, figs. 38 to 5 r; Ibid., I 874, Mem. American Acad., vol. Io, No. 3, pp. 372 to 374 , plate 3 , figs. $25,25^{\prime}$; plate 4 . figs. I to 45 ; plate 5, figs. I to $32 .-\mathrm{FEWKES}$, r 884 , Mem. Museum Comp. Zool. at Harvard College, vol. 9, No. 3, plate 9, figs. 8 to 9 , I 4 to 37 .

Pleurobrachia rhododactyla and $P$. pileus, VANHÖFFEN, E., I 895 , Bibliotheca Zoologica, Heft 20, Lfg. I, pp. I 5, I 7, 2 I.-CURRERI, I900, Boll. Soc. Ital. Zool., Roma, Anno 9, p. I92.

Pleurobrachia pileus, Chun, C., I 898, Ergeb. der Plankton-Expedition, Ctenophoren, p. I 5.-GRABE, I90I, Zeit. für wissen. Zool., Bd. 69, p. 486, Taf. 36, 37 (development of sexual organs).-Romer, I903, Fauna Árctica, Ctenophoren, Bd. 3 , p. 75 (full list of literature).-MOSER, I903, Ctenophoren der Siboga-Expedition, p. 5 (list of literature); also, I908, Zool. Anzeiger, Bd. 33, p. $756 .-$ PARKER, I905, Journal Experimental Zool., vol. 2, p. 409 (movernents of swimming plates, see Mnemiopsis).-Browne, I905, Proc. Royal Soc. Edinburgh, vol. 25, p. 784.-Moser, I go9, Ctenophoren der deutsche SüdpolarExped., Bd. II, p. I4I.-Ghigi, I909, Ctenofori, Roy. Instituto Studi Superiori, Firenze, vol. 2, fasc I, p. 9.-Evans and Ashworth, I909, Proc. Roy. Physical Soc., Edinburgh, vol. I 7. p. 308.

Pleurobrachia bachei, Agassiz, L., 1860, Cont. Nat. Hist. U. S., vol. 3. p. 294.Agassiz, A., I865, North American Acal., p. 34--TorRey, I904, Univ. California Publications, Zool., vol. 2, p. 46, plate 1, fig. 3 .

The body is egg-shaped, or almost spherical, and about 17 to 20 $\mathrm{mm}$. in length and $\mathrm{I} 4$ to $18 \mathrm{~mm}$. wide in the tentacular axis. Evans and Ashworth, I909, record a specimen $30 \mathrm{~mm}$. in length from Burntisland Harbor, Scotland, in December. It is only slightly compressed laterally in the plane transverse to the tentacular diameter, so that the lateral diameters are to each other as about Io to I2.5, the tentacular axis being the wider. The apical sense-capsule is situated upon the surface and is not sunken within a niche. It incloses a small, spherical mass of concretions and is not surrounded by protuberances, the outer surface of the apical pole-plate being smooth. The eight rows of ciliated plates are about equal in length each to each and extend from points quite near the apical sense-organ, about three-quarters the distance down the sides of the body. Each subtentacular row contains about 38 combs of cilia, and each subventral row 35 . The 2 tentacles arise from 2 deep clefts in the sides of the body which serve as sheaths into which the entire contractile portion of the tentacles may be withdrawn. The tentacle-bulbs are widely separated from the sides of the paragastric canals. When they are fully expanded the tentacles may be I 5 to 20 times as long as the body and have a linear row of numerous simple, lateral filaments which give them a delicate, feathery appearence. They are highly contractile and extremely sensitive and are constantly changing their appearance as the animal moves through the water, at times being drawn up into knotted, string-like masses, and at other times being stretched far out in graceful, sweeping curves with their lateral filaments giving them the appearance of the most exquisite onesided feathers. The mouth is a long, narrow slit, its wide axis being perpendicular to the plane passing through the tentacles. The stomo- 


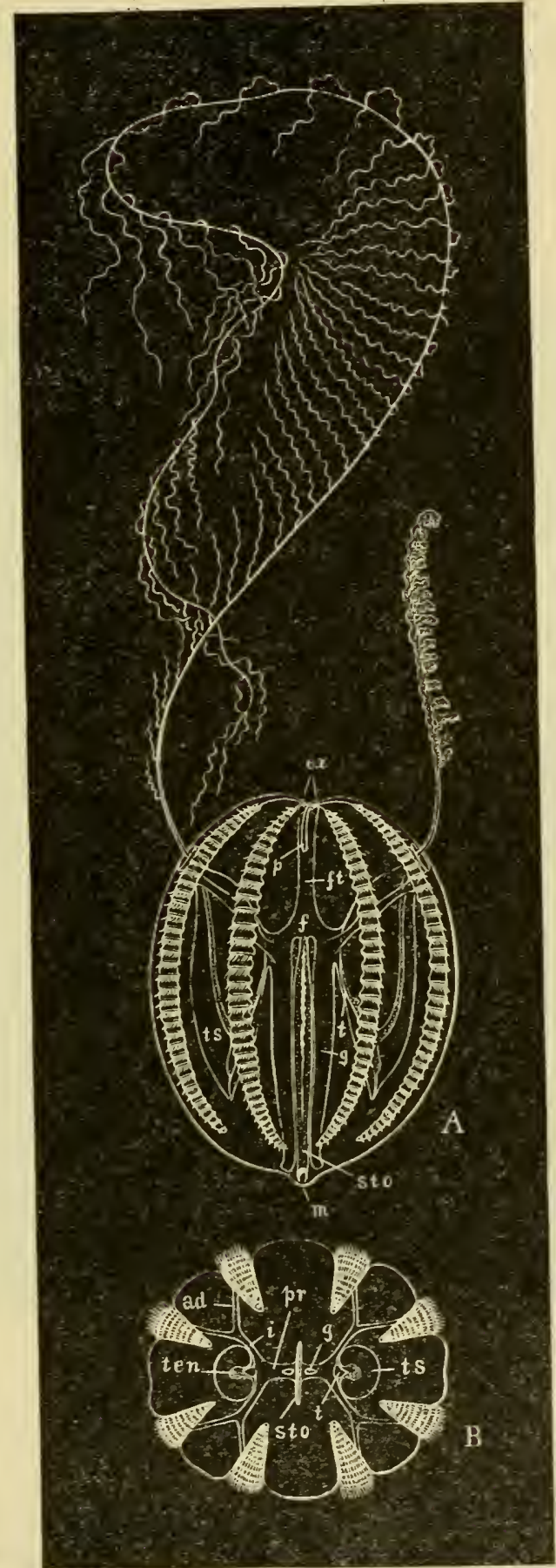

FIG. 4,-Pleurobrachia pileus, from life by the author. Halifax, Nova Scotia, September 27, I9 Iо.

$A$, side view; $\mathrm{B}$, looking down on oral pole. ad, adradial canals; ex, excretory pores; $f$, funnel or infundibulum; $f t$, axial funnel tube; $g$, paragastric canals; $i$, interradial canals; $m$, mouth; $p$, pole-plate; $p r$, perradial canals; sto, stomodæum; $t$, tentacular canals; ten, tentacles; $t s$, tentacle-sheaths. One tentacle is shown in partial contraction, the other extended. 
dæum also is wide and flat and is between one-half and one-third as long as the long axis of the ctenophore. The funnel-cavity, or mid-region of the central entodermal part of the gastric system, sends out 2 wide paragastric branches, and also 2 canals to the bases of the tentacles, and it also gives rise to 4 interradial side branches, each one of which bifurcates, thus giving a canal to each of the 8 rows of ciliated plates. The gelatinous substance is transparent and glassy, while the tentacles and stomodæum are milky, or dull orange yellow or brownish orange.

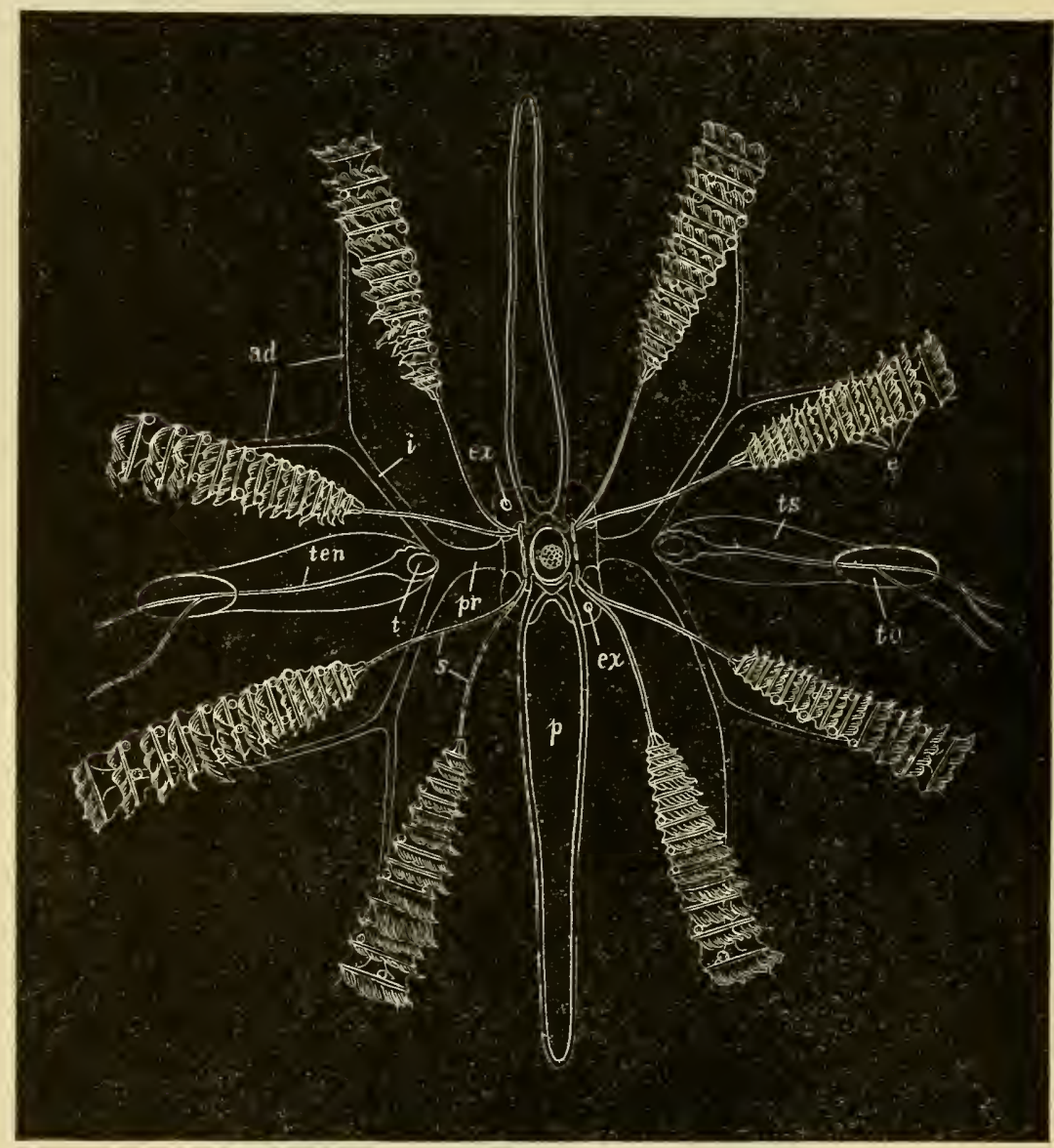

FIG. 5.-Pleurobrachia pileus; view looking down upon apical sense-organ at aboral pole of the animal.

Lettering as in fig. 4. e, ova in meridional canals under ciliary combs; $s$, sensory tracts from a pical sense-organ to rows of combs; to, opening of tentacle-sheath.

The development has been studied by A. Agassiz, I865, 1874. In common with that of other ctenophoræ, it is a simple metamorphosis. When young the tentacular diameter is about twice as great as the sagittal and the body is thus compressed laterally as in Mertensia. The combs of cilia make their appearance as 4 double rows of simple, hair-like lashes; 
later these rows separate, forming 8 rows, $45^{\circ}$ apart. The tentacles make their appearance very early in development, indeed almost as early as the combs of cilia. At first the tentacles are mere knob-like protuberances, but they rapidly elongate into simple, slender threads, and later the lateral branches make their appearance. These lateral branches begin to develop near the proximal end of the tentacle. At first the tentacle bulb arises from the outer surface of the side of the body, but later it becomes overgrown, so that finally it comes to lie at the bottom of a deep sheath-like cleft. The body of the young Pleurobrachia becomes pear-shaped and elongated, the polar axis being about I.5 times as long as the tentacular axis. Later these axes come to be almost equal, each to each, and the body is nearly spherical. The process of development of the central part of the gastro-vascular system is similar to that in Mnemiopsis. The young Pleurobrachia remains within the egg envelope until it has become pear-shaped and has 2 long, simple tentacles. While within the egg it swims about and rotates upon its axis, very much as does the adult animal in the water. When floating passively in calm water the adult ctenophore remains with its mouth upward. When it swims it progresses with the mouth forward.

This species is an inhabitant of the Arctic, and according to Moser, I908, I 909, also of the Antarctic and Pacific oceans. It extends southward in Europe into the North Sea, and in America along the coast of New England as far as Cape Cod, although winter storms drive it far southward along our coast. It is recorded from the Bermudas, but here I think the young of Bolinopsis vitrea has been mistaken for Pleurobrachia. Early in April it is found on the southern coast of New England (Newport Harbor), but as the water becomes warmer with the advance of spring it disappears and is not seen through the summer months. In the cold waters of the coast of Nova Scotia, or Maine, it frequently forms vast swarms during the summer, and at times these ctenophoræ almost touch one another over wide areas. In common with other ctenophoræ it approaches the surface most readily on calm days and a moderate ripple is usually sufficient to cause it to sink. This species appears, however, to be not so sensitive to disturbance of the water as are the larger forms, such as Mnemiopsis and Bolinopsis. On the Pacific coast of North America this ctenophore has commonly been called Pleurobrachia bachei. According to Moser it is found off New Zealand and in the South Seas, but she studied only preserved material, an almost hopeless task with ctenophores. I have never seen it at Tortugas, Florida.

Curreri, I 900 , records it from Messina, Mediterranean, stating that he found it there in great numbers in April, 1897; it seems possible, however, that he may have seen the young of Bolinopsis, which closely resembles the adult of Pleurobrachia.

In the so-called genus Cydippe, which is probably identical with Pleurobrachia, Bethe, I895 (Biol. Centralblatt, Bd. I5, p. I40), believes that he has demonstrated by means of methylen blue that there is a subepithelial nerve-plexus, the ganglion cells being multipolar, each with 3 or 4 protoplasmic processes 
Grabe, I90I, finds that in Pleurobrachia pileus the anlagen of the sexual cells are found, not only in the 8 meridional canals, but also in the paragastric and tentacular vessels. The sex-cells are apparently of ectodermal origin, as R. Hertwig, I 880 , found them to be in other ctenophores.

L. Agassiz, I849, gives beautiful figures of $P$. pileus.

Pleurobrachia brunnea sp. nov. (Figs. 2 to 4 , plate r.)

This species may be at once distinguished from the more northerly Pleurobrachia pileus by its more oblong, egg-shaped body, and especially by the opaque yellow-brown color of the stomodæum and the terminal knobs of its tentacles.

The body is egg-shaped with but little lateral compression and is $12 \mathrm{~mm}$. long. The 8 ciliated tracts are of equal lengths and extend over the middle two-thirds of the sides of the body. The 8 meridional canals extend downward a considerable distance beyond the combs of cilia and end blindly without anastomosing. The 2 tentacles arise from deep clefts which open to the exterior at the middle of the aboral half of the sides of the body. Each tentacle gives rise to about 32 simple side branches, which often coil into helices and are highly contractile. The main shaft of each tentacle terminates in a large, knob-shaped end. A row of deep purple pigment spots extends half-way down each tentacle shaft on the abaxial side, and the side branches of the proximal halves of the tentacles are also dotted over with these purple spots. The tentacles differ markedly from those of Pleurobrachia pileus in their fewer side branches and in the fact that they end each in a large knob.

This species was found by the author in large swarms off the coast of New Jersey, from Sandy Hook to Barnegat Bay, on October I6, I 904. It is separated from Hormiphora plumosa by the greater length of its meridional vessels, which extend a considerable distance beyond the oral ends of the rows of combs instead of ending with the combs, as in $H$. plumosa. The bases of the tentacles are not closely applied to the sides of the paragastric vessels as in Hormiphora, but are widely separated. Moreover, in $H$. plumosa the lower (oral) ends of the tentacle-sheaths are slightly below the ends of the meridional canals, whereas in $P$. brunnea the meridional canals extend below the ends of the tentacle-sheaths.

$P$. brunnea bears a closer resemblance to Hormiphora spatulata Chun, from the Canary Islands and the Straits of Gibraltar, but its ciliated combs begin at a greater distance from the apex than in $H$. spatulata, and the tentacles of $P$. brunnea terminate in knob-like ends instead of tapering to points. H. spatulata is described by Chun, 1898 , Ctenophoren der Plankton Expedition, p. I8, Taf. 2, 3.

\section{Genus HORMIPHORA L. Agassiz, r86o.}

Cydippe, GegenBaur, I 856, Archiv für Naturgesch., Jahrg. 22, p. 200.-SARS, M., I856, Middelh. Litt. Fauna, p. 7 I. - Panceri, I872, Atti Acad. Napoli, vol. 5, p. 2.

Hormiphora, Agassiz, L., I 860, Cont. Nat. Hist. U. S., vol. 3, p. 196.-CHUN, I 880, Ctenophoren des Golfes von Neapel, p. 280; also, I898, Ctenophoren der Plankton-Expedition, p. I6.-Moser, I903, Ctenophoren der SibogaExpedition, pp. 9, 3 I ; I908, Abhandl. Akad. München, Supplement Band $\mathbf{x}$, Abhandl. 4, p. I0; I 909 , Ctenophoren der deutsche Südpolar-Expedition, Bd. II, Zool. 3, p. 148 . 



\section{Plate 2.}

FIG. 5. Hormiphora plumosa. Specimen from Tortugas, Florida, May 29, I906.

Fig. 6. Surface view of apical pole-plate showing lithocyst. ex, excretory pores; $n$, sensory tracts from sense-organs to rows of combs; $t s$, openings of tentacle sheaths.

FIG. 7. Side view of apical sense-organ.

Fig. 8. View of tentacle. 8a. Enlarged view of appendages on base of tentacle.

Drawn from life, by the author. 


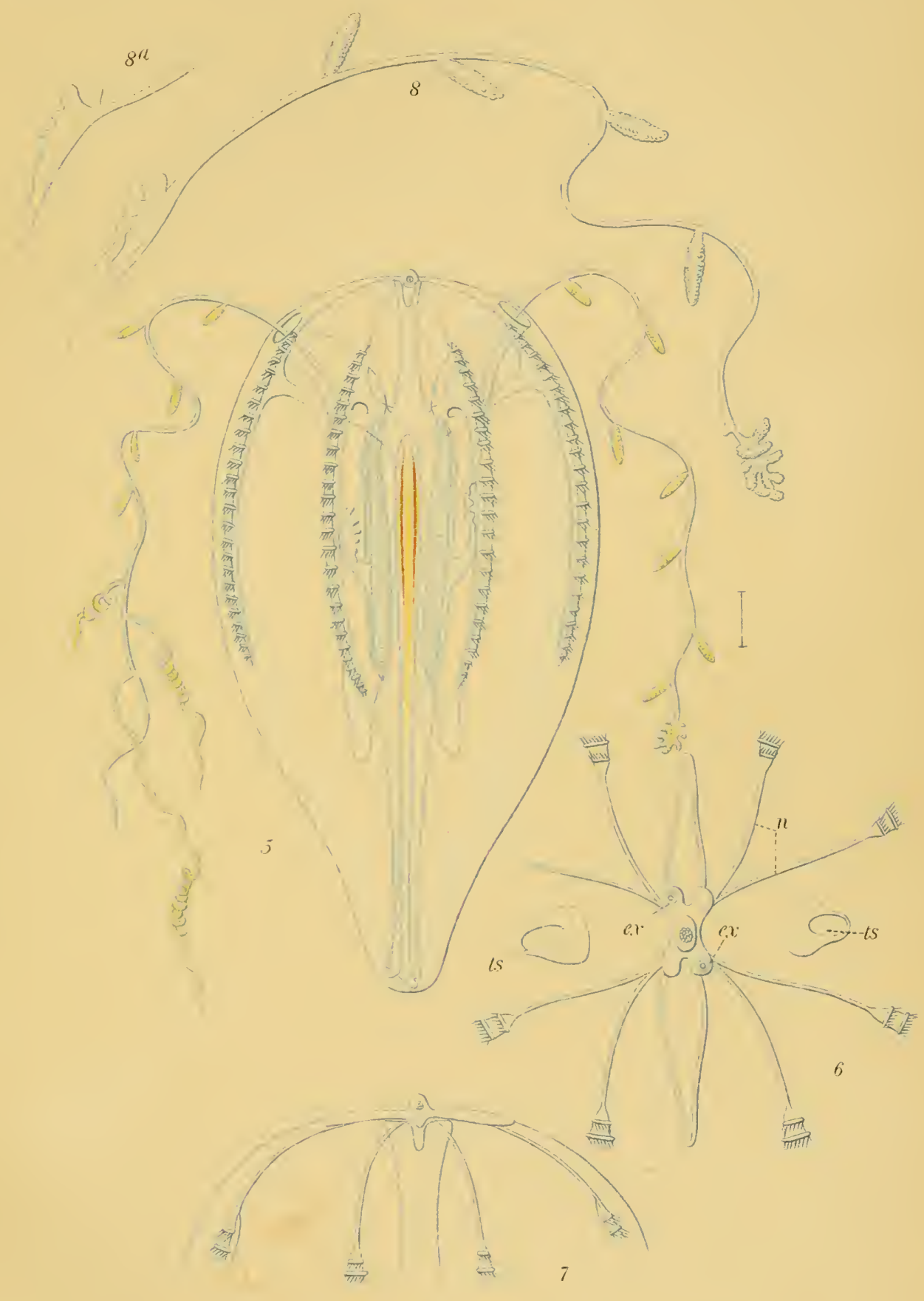



GENERIC CHARACTERS.

Body oval or egg-shaped, sagittal diameter almost as great as the tentacular axis. The animal resembles Pleurobrachia except that the tentacles usually bear two or more kinds of side branches instead of simple filaments. Also in Hormiphora the tentacle bases arise from the bottom of deep clefts close to the sides of the paragastric vessels while in Pleurobrachia the clefts are not so deep and the tentacle bases are situated at points about half-way between the sides of the paragastric vessels and the outer surface of the body.

The type species is Hormiphora plumosa of the Mediterranean.

This genus is so closely allied to Pleurobrachia that I consider its separation to have been unfortunate and future discoveries of forms will, I believe, reveal intergrades and oblige us to unite the two genera under the older name Pleurobrachia.

Moser, I903, gives a diagnosis of all of the species of Hormiphora known at that time, and in I 909 she gives a list of species with their geographical ranges.

Hormiphora plumosa L. Agassiz. (Figs. 5 to $8 a$, plate 2.)

Cydippe hormiphora, Gegenbaur, I856, Archiv für Naturgesch., p. 200, Taf. 8 fig. 10.

Cydippe plumosa, SARs, M., I856, Middelhavets Litt. Fauna, p. 7 I.

Hormiphora plumosa, AGAssiz, L., 1860, Cont. Nat. Hist. U. S., vol. 3, p. I96.CHUN, r880, Fauna and Flora des Golfes von Neapel, Monographie I, pp. 64, 28 t, Taf. I, Fign. 5, 6; Taf. 2, Fign. 2, 3; Taf. 3, Fign. 8, 9.-MAYER, 1900, Bull. Mus. Comp. Zool. at Harvard College, vol. 37, p. 82.-Moser, I903, Ctenophoren der Siboga-Expedition, p. ro.-SAMASSA, 1892, Archiv Mikroskop. Anatomie, Bd. 40, Pp. I73, 223 (histology).-Ghigi, I909, Ctenofori, Firenzi, vol. 2, p. I4.

Cydippe densa, Spagnolini, r87o, Cat. Ber. Golfo. d. Napoli, Bull. d. Nat. e Med. Napoli, p. 6I.

This Mediterranean species is occasionally found near the surface upon calm days in summer at the Tortugas, Florida, and thus it is apparently distributed from the Mediterranean across the tropical Atlantic.

The body is about I 5 to $20 \mathrm{~mm}$. long, oval, with bluntly rounded aboral pole and more or less narrowed oral pole, giving an egg-shaped outline. The shape of the body changes, however, with the states of contraction of the animal and may vary considerably in ratio of width to length. There is practically no lateral compression, the cross-section of the body being very nearly circular. The a pical sense-organ is simple and not appreciably sunken beneath the surface, and the apical poleplate bears no protuberances. There are 2 excretory pores. The 8 meridional rows of ciliated combs are all equal each to each in length. They begin at a considerable distance below the apical sense-organ and extend to the lower third of the body. The 8 meridional vessels do not extend far below the lower ends of the rows of combs. There are about 25 to 40 combs in each row. Of the chymiferous vessels, the 2 perradial are extremely short, the 4 interradial quite long, and the 8 adradial about as long as the interradial. The funnel-tube is well developed and tapers so as to be narrowest near the apical sense-organ. The stomodæum and 2 lateral paragastric tubes are simple and narrow. The 
inner end of the stomodæum contains dull-yellow and reddish-brown pigment. The 2 tentacle-bases are closely pressed to the sides of the paragastric canals. Their lower ends are simple, not hooked, and extend slightly below the level of the lower ends of the 8 meridional vessels. The tentacle-sheaths are voluminous and long, and taper upward so as to open to the outside slightly below the level of the aboral ends of the rows of combs. The tentacles bear a pair of cock's-comb-shaped expansions upon the upper sides of their bases. They also give rise to numerous, simple, filamentous side branches and a few more or less hand-shaped appendages at very irregular intervals. The side branches of the tentacles are slightly yellow. The canal-system and other parts of the entoderm of the animal are slightly milky, other parts being transparent.

This ctenophore is not common either in the Mediterranean or at Tortugas, Florida. It is beautifully figured by Chun, I880, in his Naples Monograph of the Mediterranean Ctenophoræ.

\section{Genus TINERFE Chun, sens. ampl.}

Ute, Chun, r 889, Sitzungsber. Akad. Wissen., Berlin, Jahrg., r 889, p. 525.

Ute, preoccupied by Schmidt for Sponges.

Tinerfe, Chun, r898, Ergeb. der Plankton-Exped., p. 6.-Moser, r9o9, Ctenophoren der deutsche Südpolar-Expedition, Bd. I I, Zool. 3, p. I3 I.

Chun defines this genus of the Cydippidæ as follows:

Body cylindrical, only slightly compressed in the stomodreal plane. Two kidney-shaped, gelatinous protuberances project above the apical sense-organ in the funnel-plane. Paragastric vessels well developed. Tentacle-bases long. Genital products developed only in the 4 subtentacular meridional vessels.

The generic designation cited above applies to two small Ctenophoræ from Tortugas, Florida, with the exception that the gelatinous swellings flanking the sense-organ are mammiform in one and papilliform in the other species, not kidney-shaped, and the genital products are developed in all of the 8 meridional vessels. Also the tentacle bases of one species are short, not long. We might profitably amplify Chun's definition of the genus and avoid stating the precise shape of the protuberances on the sides of the apical sense-organ, and omit the restriction that the genital products develop in only 4 of the meridional vessels, for this is probably only an indication of immaturity; or that the tentacle-bulbs be either long or short.

We would thus amplify Chun's definition to read as follows: Cydippidæ with nearly cylindrical body, only slightly compressed in the stomodæal-axis. With protuberances in the funnel-plane on both sides of the apical sense-organ. Paragastric canals well developed. Tentacles sunken within sheaths in the funnel axis. Tentacles with lateral filaments.

Chun's Tinerfe cyanea from the Canary Islands is the smallest ctenophore known, being only 2 to $2.5 \mathrm{~mm}$. long when mature. The Tortugas forms, Tinerfe lactea and $T$. beehleri, are also very small, being only $9 \mathrm{~mm}$. long. The type species is Tinerfe cyanea Chun. 



\section{Plate 3.}

FIG. 9. Tinerfe lactea sp. nov. Tortugas, Florida, July 3, Igo6.

Fig. 10. Tinerfe beehleri sp. nov. Tortugas, Florida, May 9, 1906. Body-walls contracted so as to form 8 temporary mounds above sense-organ.

FIG. II. Tinerfe beehleri. Sense-organ seen from side, body normally expanded so that there are no mounds around sense-organ.

Drawn from life, by the author. 


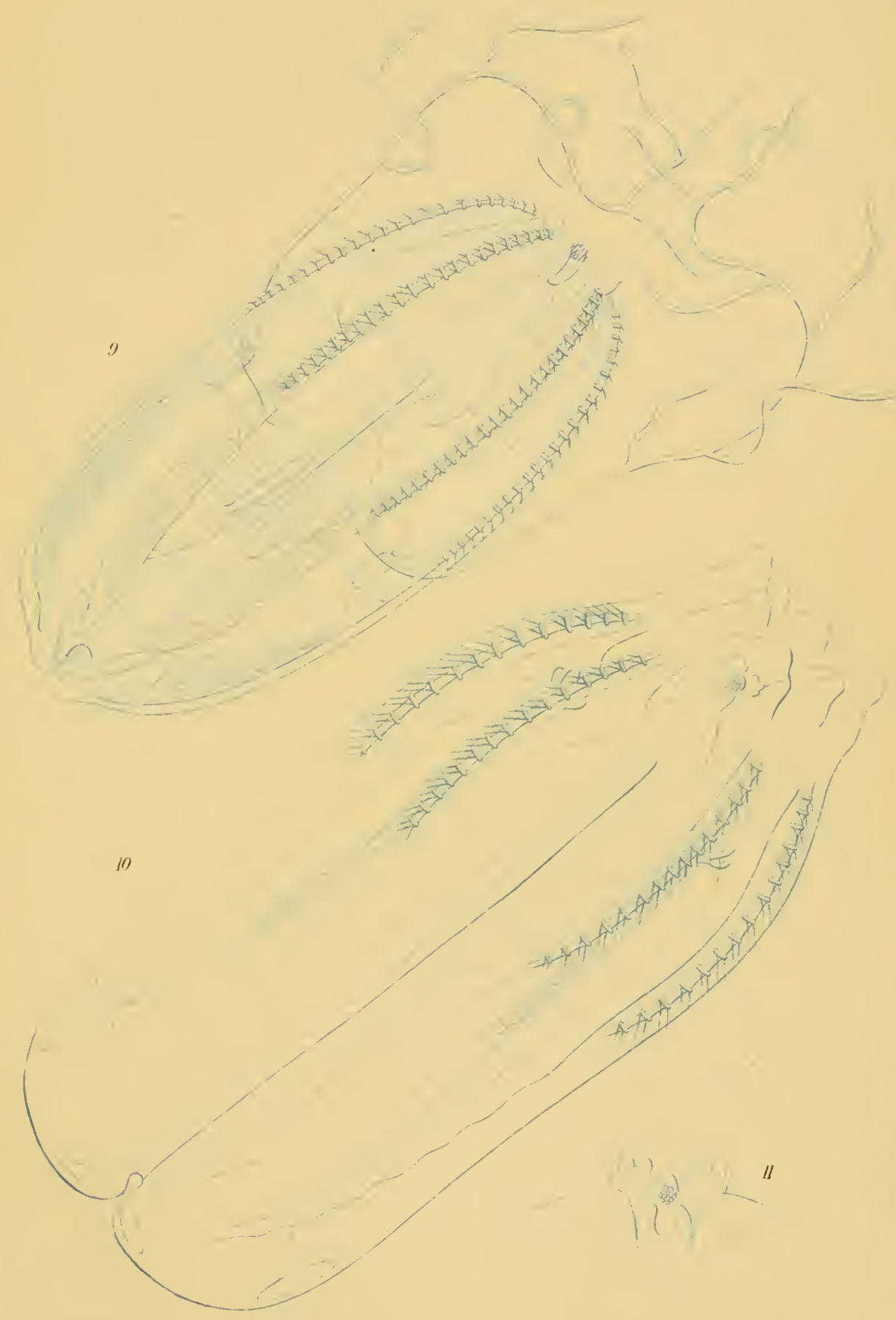



Tinerfe lactea sp. nov. (Fig. 9, plate 3.)

Body oval, $9 \mathrm{~mm}$. long, $5 \mathrm{~mm}$. wide in the funnel-plane, and $3 \mathrm{~mm}$. wide in the stomach-plane. The apical sense-capsule is raised above the general body-surface and is covered with bristles. It is flanked on both sides in the tentacular-diameter by 2 prominently projecting, mammiform, gelatinous papillæ. The 8 rows of combs are of equal length and extend from very near the apical sense-organ to the middle of the sides of the body. Each row consists of about 25 combs. The 8 meridional canals extend beyond the lower ends of the rows of combs and taper to simple, pointed ends near the mouth, the 4 subtentacular vessels being slightly longer than the 4 subventral. All of these canals widen laterally below the lower ends of the rows of combs, and their lower ends are filled with genital products. The funnel-tube is wide and flat, and lyre-shaped in outline. The stomodæum is well developed and there are 2 narrow, lateral, paragastric canals in the tentacular diameter. The tentacle bases are long and pressed closely against the sides of the paragastric canals. The wide tentacle-sheaths proceed straight outward, opening at the middle points of the sides of the body. The 2 long, tapering tentacles have each a few simple, filamentous side-branches.

When mature the eggs are cast out through the side walls of the 8 meridional canals. The animal is very active. The body is milky and translucent. It is a rare ctenophore and I have seen only 3 specimens, all found in July, near the surface, about 4 miles from land off Tortugas Islands, Florida.

Tinerfe beehleri sp. nov. (Figs. ro and Ir, plate 3.)

Named in honor of Commodore William H. Beehler, U. S. N., formerly commandant at Key West; for many years the most constant, kindly, and powerful friend of the Tortugas Laboratory of the Carnegie Institution of Washington.

Body nearly cylindrical, $9 \mathrm{~mm}$. long and $4.2 \mathrm{~mm}$. wide, with only slight compression in the stomodæal-axis. It is difficult to determine the amount of this compression, however, for the shape of the animal almost constantly changes through vermiform contractions of the bodywall. Indeed, these movements seem to aid in some measure in enabling the creature to swim. At times the aboral pole is evenly rounded and dome-like, while at others contractions cause 8 mounds to project above the apical sense-organ, as is shown in fig. Io, plate 3 . The sense-capsule is simple and not sunken within a furrow, but on both sides of it in the funnel-axis there are papilliform swellings. The 8 rows of ciliary combs are less than half as long as the body and are all of equal length. Each row consists of about I5 combs. They are widely separated from the apical sense-organ.

The stomodæum is well developed and laterally flattened. The funnel is large, but the axial funnel-tube is very short and is cleft for about half its length by the basal part of the sensory cushion of the lithocyst-plate. The interradial and adradial canals extend from the aboral ends of the rows of cilia to near the level of the mouth. These 
meridional vessels are wide and their edges exhibit a wavy outline, probably due to contraction. The 2 paragastric vessels are well developed and closely pressed to the sides of the stomodæum. They flare outward at the level of the mouth. The 2 tentacular canals are very short and the tentacle bases small, but the sheaths are correspondingly long and extend downward and finally outward, to open very near the mouth at about the level of the oral ends of the meridional canals. I have never seen the tentacles protrude beyond the sheaths, but they appear to have lateral filaments.

I have not seen the genital products and can not state that the specimens were mature, for the dull milky color of this animal renders it only about as translucent as ground glass, so that minute details of its internal structure can be seen only with difficulty. It is rare and I have seen only 4 specimens between May and July at Tortugas, Florida. It comes to the surface only when the water has been calm and unrippled for some hours.

\section{Order LOBAT $\notin$ L. Agassiz, 1860.}

Beroide lobate, Eschscholtz, I 825 , Isis, p. $74 \mathrm{I}$.

Mnemiide, Eschscholtz, I 829, Syst. der Acal., p. 29.

Callianiride, Mertens, I833, Mém. Acad. St. Pétersbourg, sér. 6, tome 2, p. 495. Calymmide, Gegenbaur, I 856, Archiv für Naturges., Jahrg. 22, p. I92.

Lobatce, Agassiz, L., i 860 , Cont. Nat. Hist. U. S., vol. 3, pp. I99, 289.-Agıssiz, A., I 865 , North Amer. Acal., p. I 4.-CHUN, i 880, Ctenophoren Golfes von Neapel, p. 287 , I 898 , Ctenophoren der Plankton-Expedition, p. 22.-VANHÖFFEN, I906, Nordisches Plankton, Ctenophoren, p. 4.-Mose R, I903, Ctenophoren der Plankton-Expedition, p. I6; also, I908, Abhand1. Akad. München, Suppl. Bd. I, Abhandl. 4, p. 36; also I, r 909 , Ctenophoren der deutsche Sudpolar-Exped., Bd. I I, Zool. 3, p. I6I.

\section{CHARACTERS OF THE LOBATE.}

The body is laterally compressed, the gastric axis through the stomodæum and oral lobes being longer than the funnel-axis through the lateral tentacles. There are 2 oral lobes, I on each side of the mouth. At the lower ends of each of the subtentacular combs of cilia there are 4 freely projecting, ribbon-like auricles which are fringed along their narrow edges with cilia. The 4 principal, interradial, entodermal canals spring directly from the funnel. The meridional canal-system communicates with the 1 -shaped oral ends of the 2 paragastric tubes and also winds in a more or less complex manner in the substance of the oral lobes. The tentacle bases are near the oral pole. There are no tentacle-sheaths.

The larva passes through a Mertensia-like stage, and in Leucothea the animal may become sexually mature while in this condition.

It is evident that the Lobatæ are derived from the Cydippidæ and that they came from Mertensia-like ancestors.

It is interesting also to see that the Cestidæ are closely related to the Lobatæ, and the canal-systems of the Cestidæ and Beroidæ are somewhat similar each to each in their general features. 


\section{Genus LESUEURIA Milne-Edwards, r84I.}

Lesueuria, MiLNE-Edwards, H., I 84 I, Annal. des Sci. Nat., sér. 2, tome 66, p. i99.-Lesson, I 843, Hist. Zooph. Acal., p. 90.-Agassiz, L., i860, Cont. Nat. Hist. U. S., vol. 3, p. 290.-Agassiz, A., 1865, North Amer. Acal., p. 23.Chun, i 880 , Ctenophoren des Golfes von Neapel, pp. 290, 291.-VANHöfFen, I906, Nordisches Plankton, Ctenophoren, p. 4.-Moser, I908, Abhandl. Akad. München, Suppl. Bd. I, Abhand1. 4.

\section{GENERIC CHARACTERS.}

Lobatæ with rudimentary oral lappets and with long, ribbon-shaped auricles. The peripheral gastro-vascular system is simple, without complex windings.

The type species is Lesueuria vitrea of the Mediterranean.

The so called American species L. hyboptera is said to be more nearly rectangular in outline than the oval-shaped $L$. vitrea of Europe. In the American form the body is wider both above and below than it is in the middle, thus giving it somewhat the appearance of a laterally flattened hour-glass.

\section{Lesueuria hyboptera A. Agassiz.}

Lesueuria hyboptera, AGAssiz, A., 1 865, North Amer. Acalephæ, p. 23, figs. 25-28.VANHÖFFEN, I 895, Bibliotheca Zoologica, Heft 20, Lfg. I, p. I8.

The body of the adult animal is roo $\mathrm{mm}$. long, while the broad side (stomodæal axis) is $50 \mathrm{~mm}$. and the narrow side (funnel-axis) is $30 \mathrm{~mm}$. The lateral compression is thus almost as great as in Mertensia, but of reverse character, the gastric axis of Mertensia being the narrower. The body is widest at about the level of the mouth. The apical senseorgan lies at the bottom of a narrow cleft about $12 \mathrm{~mm}$. in depth. The 4 subtentacular rows of ciliated combs are each about half as long as the body and terminate near the bases of the 4 auricles. These auricles are very large, being almost $50 \mathrm{~mm}$. in length. They are wide and ribbonshaped and their free edges are lined with a row of hair-like cilia. The 4 subventral rows of ciliated combs are longer than the 4 subtentacular rows and extend over fully three-fourths of the length of the body. The 2 oral lappets are short and blunt, being not more than one-tenth as long as the body of the animal. This bluntness imparts an almost rectangular appearance to the creature when seen from the broad side. The stomodæum is long and narrow, while the funnel-tube is very short. The tubes of the peripheral canal-system are extremely narrow and exhibit no complex windings. The 4 subtentacular meridional vessels wind somewhat as they enter the auricles, while the 4 subventral meridional tubes are quite straight and do not wind as they extend through the substance of the oral lappets. The animal is almost transparent, being of a slightly milky hue. It gives rise to an intense steel-blue phosphorescence when disturbed at night.

This species must be a very rare and occasional visitor to our coast. A. Agassiz found it in great numbers in Massachusetts Bay and Newport Harbor about $\mathrm{i} 860$, but it has never been seen since that time. It is interesting to notice that M'Intosh, 888 (Ann. and Mag. Nat. Hist., ser. 6 , vol. 2), reports the sudden appearance of great swarms of a species of Lesueuria, possibly Bolinopsis?, off the coast of Scotland. The foregoing description is derived entirely from A. Agassiz, who is the only 
observer of the American Lesueuria, and I am beginning to suspect that this so-called Lesueuria is only a Bolinopsis infundibulum with its oral lobes torn off and the edges healed over to produce a rounded contour, for I found many specimens of this ctenophore in Halifax Harbor in such condition after a storm in September.

Genus BOLINOPSIS L. Agassiz. (sens, emend.)

Bolina, preoccupied by RAFINESQUE for mollusca in I 8 I 5 .

Bolina, Mertens, I833, Mém. Acad. Sci. St. Petersbourg, Sci. Math. et Nat., ser. 6, tome 2, p. 5I3.-Agassiz, L., I 849, Mem. Amer. Acad., vol. 4, p. 349; also, I 860 , Cont. Nat. Hist. U. S., vol. 3, p. 249.-Patterson, I839, Trans. Roy. Irish Acad., vol. I9, p. I 54.-Agassiz, A., I 865, North Amer. Acal., p. I 4.CHUN, I880, Ctenophoren Golfes von Neapel, pp. 290, 292.-von LENDENFELD, I885, Proc. Linnean Soc. New South Wales, vol. 9, part 4, p. 929.CHUN, I898, Ctenophoren der Plankton-Expedition, p. 22.-Moser, I9o8, Abhandl. Akad. München, Suppl. Bd. I, Abhandl. 4, p. 47.

Springbrunner-Rotzfisch, MARTENS, I675, Spitzbergische Reisebeschr., p. I3I.

Beroé, Müller, O. F., I 776, Zool. Danica, Prodromus, Nr. 28I6, p. 232.

Mnemia, SARS, M., I 835 , Beskriv. og Jagttagelser, p. 23.

Bolina, Alcinoe, Anais, Lesson, I843, Hist. Zooph. Acal., pp. 83, 89, ror. Anais, preoccupied for Aves by Lesson, 1840 .

Bolinopsis, Agassiz, L., I 860, Cont. Nat. Hist. U. S., vol. 3, p. 290.

Unfortunately, the old and familiar generic name Bolina is preoccupied, having been used in 1815 for mollusca by Rafinesque. Alcinoé of Rang, 1828 , and Mnemia of Eschscholtz, 1829, apply to a ctenophore which is certainly not a Bolina but is closely allied to if not identical with Mnemiopsis. Lesson's Anais, I843, was preoccupied by himself in I 840 for birds, and Hapalia of Eschscholtz, I 825, is founded upon an imperfect specimen which may possibly be a Bolina, but even so the name Hapalia is preoccupied for Lepidoptera by Hübner in 1816 .

Bolinopsis of L. Agassiz, I860, is the only one of these names which can be applied to the genus. Agassiz instituted this name to apply to the Bolina elegans of Mertens, r833, and he separated it from Bolina on account of the numerous, small papillæ which are found upon all parts of the outer surface of the body, except the lower parts of the oral lobes. We may, however, consider this to be a specific rather than a generic character, especially as by so doing we will not confuse this genus with Leucothea (Eucharis), wherein the papillæ are much larger and cover the whole of the outer parts of the oral lobes. Moreover, the lateral pits in the tentacular axis, so well developed in Leucothea, are not found in Bolinopsis. Thus by broadening the definition of Bolina we may retain it under the somewhat similar name Bolinopsis. I prefer to do this rather than to institute a new and wholly unfamiliar name.

\section{GENERIC CHARACTERS.}

Lobatæ in which the 2 oral lobes are of medium size and not provided with powerful muscles as in Ocyropsis. The 4 relatively short, simple auricles arise from the sides of the body immediately above the mouth and close to the sides of the oral lobes. They are not set within deep grooves as in Mnemiopsis. The peripheral chymiferous tubes form closed circuits in the oral lobes and do not end blindly as in Deiopea. The auricles are shorter and the oral lobes much longer than in Lesueuria. The combs of cilia are small and numerous.

The type species is Bolinopsis infundibulum of the Arctic and cold temperate regions. 
This genus is closely related to Mnemiopsis, for Mnemiopsis in its growth passes through a Bolinopsis stage. Phylogenetically speaking Bolinopsis is simply an arrested form of Mnemiopsis, or Mnemiopsis an advanced condition of Bolinopsis.

\section{Bolinopsis infundibulum. (Figs. 12 to 15 , plate 4 .)}

Springbrunner-Rotzfisch, MARTENS, I 675, Spitzbergische oder Grönlandische Reisebesch., p. I 2 I, Taf. P.

Beroé ovata, BASTER, I762, Opscula subsecina, Bd. I, P. I 24, Tat. I4, fig. 5 .

Volvox beroé, LINNæUS, I 768, Systema Naturæ, ed. I 2, Part 4, Corals, p. 9 Io.

Beroé infundibulum, Mǘl一e, O. F., I 776, Zoologicæ Danicæ, Prodromus, p. 232, Nr. 28 I6.-FABRICIUS, O., I 780 , Fauna Grönlandica, p. 360, No. 352.

Bolina infundibulum, CHUN, I880, Ctenophoren des Golfes von Neapel, pp. 293, 294.-RömER, I903, Fauna Arctica, Bd. 3, Ctenophoren, p. 78 (full list of literature).-VANHÖFFEN, I go6, Nordisches Plankton, Ctenophoren, p. 5, fig. I I.-BRowNE, I905, Proc. Royal Soc. Edinburgh, vol. 25, p. 784.-Evans and Ashworth, I909, Proc. Roy. Physical Soc. Edinburgh, vol. I 7, p. 309 , fig. Bolina norvegica, VoGT UND YUNG, I 888, Lehrbuch der Vergleich. Anatomie, Bd. I, p. I 70, Fign. $7 x-85$.

Bolina septentrionalis, Mertens, $x 8_{33}$, Mém. Acad. des Sci., St. Pétersbourg, Sci. Math. Phys. et Nat., sér. 6, tome 2, p. 515, Taf. 7, fign. I-5.

Bolina alata, Agassiz, L., I 849, Mem. American Acad., vol. 4, part 2, p. 349, plates 6-8; also, I860, Cont. Nat. Hist. U. S., vol. 3, pp. 249, 289.-STIMPSON, I 853 , Marine Invert. Grand Manan, P. I I.-PACKARD, I 863 , List of Animals dredged near Caribou Isd., Canadian Naturalist and Geologist, vol. 8.- AGASsIz, L., I865, North American Acal., p. I 5, figs. I-1 8.-AGAssiz, A., 1874 , Mem. American Acad. Arts Sci., vol. Io, No. 3, p. 376, figs. 3-I 2.-VANHÖFfEN, I895, Bibliotheca Zoologica, Heft 20, Lfg. I, p. I9.

Alcynoé vermicularis, Gould, I 84 I (non Rang); Invert. of Mass., p. 349.

The adult (fig. I 4 , plate 4 ) is about i io to $150 \mathrm{~mm}$. long. The aboral end is bluntly pointed and subconical, while the oral lobes are large and rounded. Thus the general outline of the body is pear-shaped, although the creature is compressed laterally. The lobes are about onethird as long as the body of the animal. The apical sense-organ is placed at the bottom of a deep, narrow cleft. It is very minute and contains a mass of small, white concretions. The 4 subtentacular rows of combs arise from the summit of the conical, aboral end of the animal and extend straight down to the bases of the 4 auricles, which arise from the sides of the animal at points about one-third the distance from mouth to apical sense-organ. The subtentacular rows contain each about 35 to 40 combs, while the auricles are edged with a linear row of ciliary combs. The auricles are flat and ribbon-like and about one-quarter as long as the entire animal. The 4 subventral combs of cilia arise from the base of the conical, aboral end of the animal and extend straight down to points near the free, outer ends of the oral lobes. Each of these rows consists of about 50 combs which extend about two-thirds the entire length of the animal and reach a level lower than that of the ends of the 4 subtentacular rows. The oral lobes are wide, rounded, and flexible and are commonly folded so as to overlap on both sides of the mouth. Their inner sides are provided with delicate longitudinal and transverse muscles, the contractions of which enable the animal to compress the lobes with considerable force, although not with sufficient rapidity to be of any appreciable service in swimming, this being accomplished almost exclusively through the movements of the combs of cilia. There is a 
row of small, thread-like, simple tentacles on both of the wide sides of the mouth. The median tentacles, one on each side in the axial plane, are longer than the others and are provided with simple, lateral filaments. These are the primary tentacles of the larva which still persist in the adult. The stomodæum is long and narrow, and the mouth is a long cleft, perpendicular to the tentacular diameter. The funnel is very short, being only about one-seventh as long as the stomodæum. The peripheral tubes of the gastro-vascular system are of small caliber. The meridional ventral tubes give rise to very complex and variable windings in the oral lobes. The entire animal is almost transparent, but when mature is slightly milky in hue.

The development has been studied by A. Agassiz. The general appearance of the very young animal is quite similar to that of the young Pleurobrachia or Mertensia. The 2 tentacles of the young larva are long and flexible and are provided with numerous, simple lateral filaments, as in Mertensia. The stomodæum and the chymiferous tubes are more slender in the young Bolinopsis than they are in Pleurobrachia. As development proceeds, the general outline of the body becomes eggshaped, the aboral pole being blunt, and the tentacular diameter compressed. The oral lobes appear quite late on both sides of the mouth and still later the auricles begin to develop at the inner angles of the bases of the lobes. At the same time the bases of the 2 tentacles begin to migrate downward toward the sides of the mouth, carrying their chymiferous tubes down with them. The meridional tubes are at first simple and blindly ending as in Mertensia, and lie immediately under the combs of cilia; but when the oral lobes begin to develop they extend downward and finally form closed loops by the fusion of their free ends. Thus the meridional ventral tubes of adjacent sides are joined through complex windings in the oral lobes; while the meridional tentacular tubes extend outward through the auricles and downward around the free lower borders of the oral lobes. They also join with the oral forks of the lower ends of the paragastric canals, thus forming a closed circuit around the mouth. The details of the development are fully described and illustrated by A. Agassiz, I 865, I 874 .

This is one of the commonest ctenophores along the New England coast north of Cape Cod. It is not found on the southern coast of New England, but is exceedingly abundant off the coast of Newfoundland, or northern Maine in summer. It also occurs throughout the Arctic regions and off the coasts of Norway and Scotland, and southward to the shores of Northern Germany. I believe that Bolina septentrionalis of Mertens, I 833 , is this same ctenophore from Behring Sea.

Römer, I903 (Fauna Arctica, p. 80), gives a detailed account of its distribution and a long list of its synonyms.

Bolinopsis vitrea. (Figs. I 6 to $\mathrm{x} 9$, plate 5.)

Bolina vitrea, Agnssiz, L. I 860 , Cont. Nat. Hist. U. S., vol. 3, pp. $250,269,289$, fig. 93-Acassiz, A., I 865, North Amer. Acalephæ, p. I9, fig. I9.-CHUN, I 898, Ctenophoren der Plankton-Expedition, p. 22 . -MAYER, I900, Bull. Museum Comp. Zool. at Harvard College, vol. 37, p. 81, figs. 91, 92, plate 27 . Bolina hydatina, Chun, I880, Ctenophoren des Golfes von Neapel, p. 292, Taf. 4, fign. 5,6 . 

Plate 4 .

Bolinopsis infundibulum.

FIG. I2. Side view of half-grown specimen, twice natural size. Eastport, Maine, August 20, I897.

FIG. I3. Side view of half-grown specimen, twice natural size, showing winding course of meridional ventral vessels in oral lobes. Eastport, Maine, August 23, 1897.

Fig. I4. Side view of full-grown specimen, natural size. Eastport, Maine, September 22, I898.

Fig. I5. Sense-organ of ctenophore shown in figure I4.

Drawn from life, by the author. 

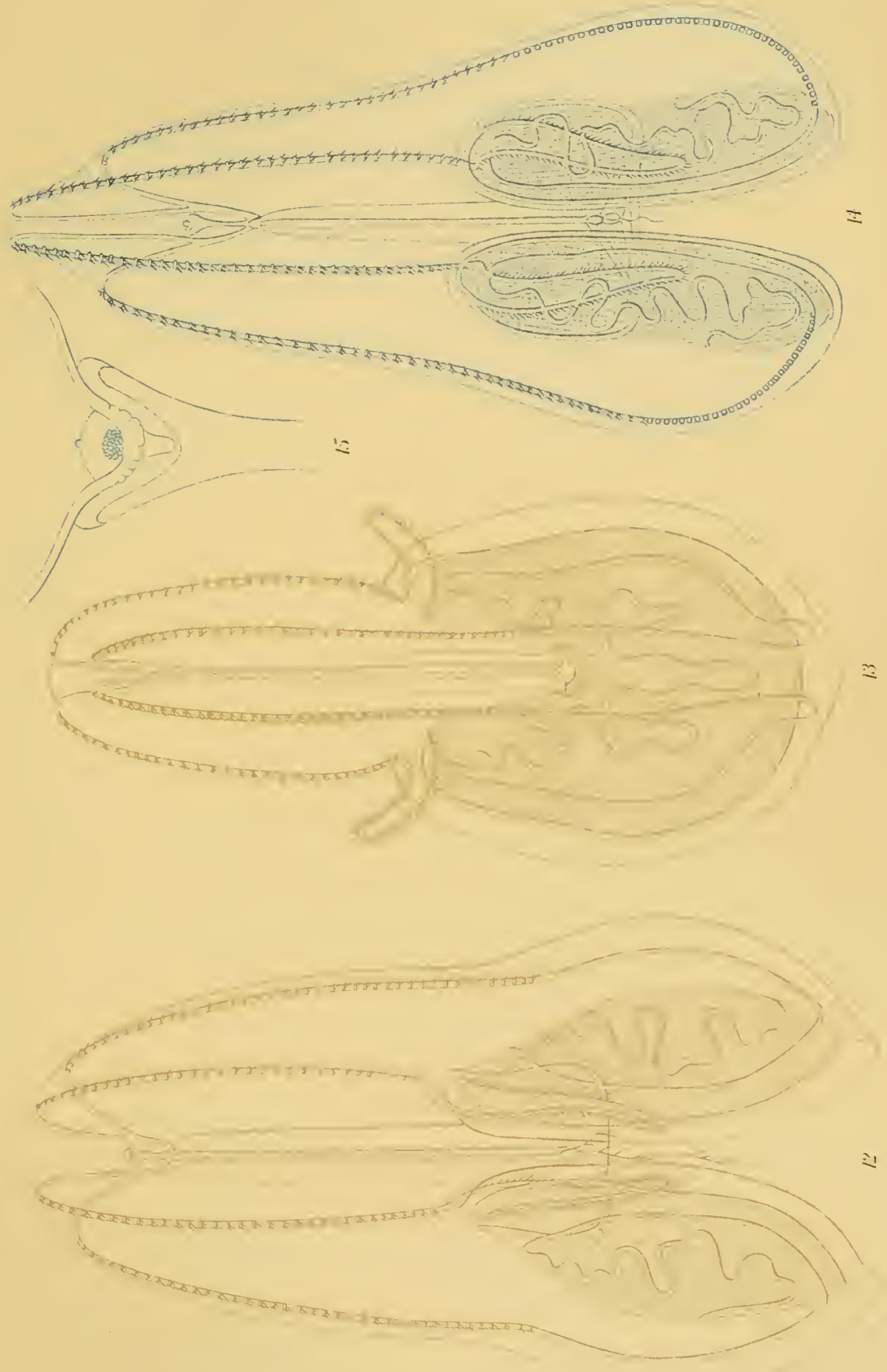

In the adult the body is oval, bluntly pointed above, and there is considerable lateral compression, the tentacular diameter being only a little more than one-half as wide as the transverse. The creature is about $80 \mathrm{~mm}$. long. The aboral apex is quite blunt and the oral lobes are wide and about three-quarters as long as the remaining portion of

Table showing the dimensions in mm. of specimens of B. vitrea from Tortugas, Florida, taken in June, rgro.

\begin{tabular}{|c|c|c|c|c|c|c|}
\hline & $\begin{array}{l}\text { Speci- } \\
\text { men A. }\end{array}$ & $\begin{array}{l}\text { Speci- } \\
\text { men B. }\end{array}$ & $\begin{array}{l}\text { Speci- } \\
\text { men C. }\end{array}$ & $\begin{array}{l}\text { Speci- } \\
\text { men D. }\end{array}$ & $\begin{array}{l}\text { Speci- } \\
\text { men E. }\end{array}$ & $\begin{array}{l}\text { Speci- } \\
\text { men F. }\end{array}$ \\
\hline Total length of body............. & 80 & 60 & $6 \mathbf{I}$ & 63 & 60 & 59 \\
\hline $\begin{array}{l}\text { Length from aboral apex to mouth... } \\
\text { Maximum width in average expansion }\end{array}$ & $5^{8}$ & 49 & 40 & 43 & 36 & 39 \\
\hline of the stomodaal axis ........... & 46 & 39 & . & 45 & 44 & 40 \\
\hline Width of body in tentacular axis .... & 23 & 22 & 22 & 24 & $2 \mathrm{I}$ & 23 \\
\hline Width across expanded lobes........ & 38 & 45 & 52 & 39 & 40 & 38 \\
\hline 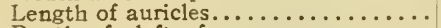 & 20 & 19 & 16 & 16 & 15 & 15.5 \\
\hline Depth of cleft of sense-organ...... & 9 & 9 & 5 & 7 & $5 \cdot 5$ & 8 \\
\hline Length of short rows of combs...... & 37 & 28 & 23 & 28 & $2 I$ & 27 \\
\hline Length of long rows of combs....... & 73 & 57 & $5 \mathrm{r}$ & 47 & 41 & 48 \\
\hline Length of funnel-tube.............. & 3 & 3 & 2 & 3 & 3 & 3 \\
\hline
\end{tabular}

the body. The apical sense-organ is situated in the bottom of a wide but not very deep cleft (text-fig. 6). The 4 auricles are edged by a linear row of ciliary combs, and arise from the sides of the body at a short distance above the mouth and close to the sides of the lappets. The lappets are flat and lanceolate and are each about one-fifth as long as the entire animal. The 4 subventral rows of ciliated combs are about twice as long as the 4 subtentacular rows. The combs of cilia are small and numerous, there being about 80 to Ioo on each subventral row and 40 to 60 on each subtentacular row. There is a row of short, simple tentacles on each side of the mouth, extending upward along the sides of the lappets to the bases of the auricles. The tentacle at the center of each row on the mid-axial line is longer than the others and is provided with simple, lateral filaments. The edges of the auricles are fringed with long, closely-crowded cilia. The stomodæum is long and narrow, and the funnel is short, being about one-fifth as long as the stomodæum. The chymiferous tubes are of fine caliber, and the windings of the meridional ventral tubes in the oral lappets are very simple, not complex as in $B$. infundibulum. The oral lappets are provided with a delicate network of longitudinal and transverse muscle fibers. The gelatinous substance is of very delicate consistency and is either transparent or diffusely tinged by a faint pink. The peripheral chymiferous tubes are of a more decided pink and in the lappets these tubes often display masses of intense pink color, probably due to products of digestion or excretion.

When about $7 \mathrm{~mm}$. long (fig. I6, plate 5), the body is oval with the two poles of about equal bluntness. Two long, flexible tentacles arise from the middle points of the sides of the body. These tentacles are highly contractile and give rise to numerous short, lateral filaments. They arise from the surface of the body and are not protected by sheaths. The apical sense-organ consists of a capsule containing a small mass of hyaline concretions. It lies at the bottom of a shallow depression. There is as yet no trace of the lappets, but the adjacent meridional subventral tubes have fused, forming simple, closed loops. The 4 meridional subtentacular tubes have joined with the circumoral vessel. When 
the animal is $8 \mathrm{~mm}$. in length (fig. $\mathrm{Ig}$, plate 5) the oral lappets begin to develop as 2 short flaps, each about one-fifth as long as the animal itself. The 4 auricles appear as short ciliated projections from the sides of the body over the subtentacular canals. The subventral canals form simple loops in the substance of the lappets. The 8 rows of ciliated plates are still of equal length each to each.

This species is found along the coast of Florida and in the West Indies and probably extends as far north as Charleston, South Carolina. It is also found in the Mediterranean. Upon calm, hot days it approaches the surface in great numbers, but rough weather soon causes it to sink into the depths. They are often common during the summer, floating near the surface in shallow water in the Florida-Bahama region.

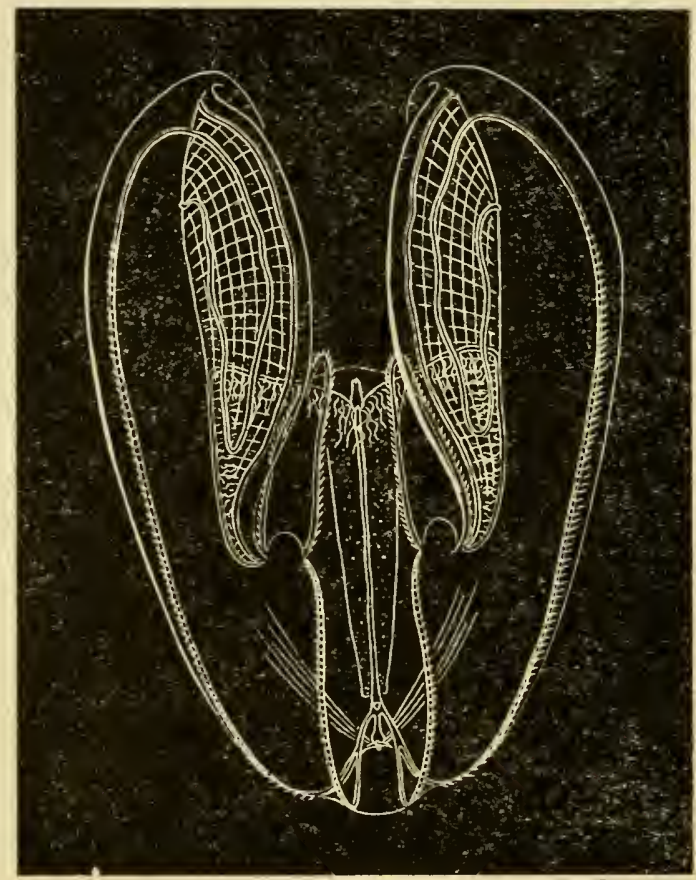

Fig. 6.-Bolinopsis vitrea, 1.25 natural size. Tortugas, Florida, June 21, Igro. Drawn from life, by the author.

The pink coloration of this form is very variable, some individuals being translucent and colorless, while others exhibit large, deep-colored masses of pink pigment in their chymiferous tubes, or pink diffused through their gelatinous substance. It is distinguished from the Arctic $B$. infundibulum by its blunter aboral apex, its relatively longer oral lobes, the much simpler windings of the meridional ventral vessels in its oral lobes, and its commonly present pink coloration. Its eggs are cast out in great masses during the warm months and the young are common in spring and summer. Altogether, it is the commonest ctenophore of the Bahama-Florida region. 



\section{Plate 5.}

Bolinopsis vitrea.

Fig. I6. Larva of Bolinopsis vitrea, $7 \mathrm{~mm}$. long, in the Cydippidæstage. Tortugas, Florida, May 17, I 899 .

Fig. I 7 . Surface view of apical pole of larva represented in figure i6. $a d$, adradial canals; $c$, subtentacular meridional canals; $c$ pr, perradial canals; $i$, interradial canals; $p$, pole-plate; tv, tentacular canals; $v$, subventral meridional canals.

FIG. I8. Surface view of mouth of larva shown in figure i6. Lettering as in figure $17 . g c$, paragastric canals; st, mouth opening and stomodæum.

Fig. I9. Young Bolinopsis vitrea, $8 \mathrm{~mm}$. long with oral lobes and auricles beginning to develop. Tortugas, Florida, May 2 I, 1899 .

Drawn from life, by the author. 


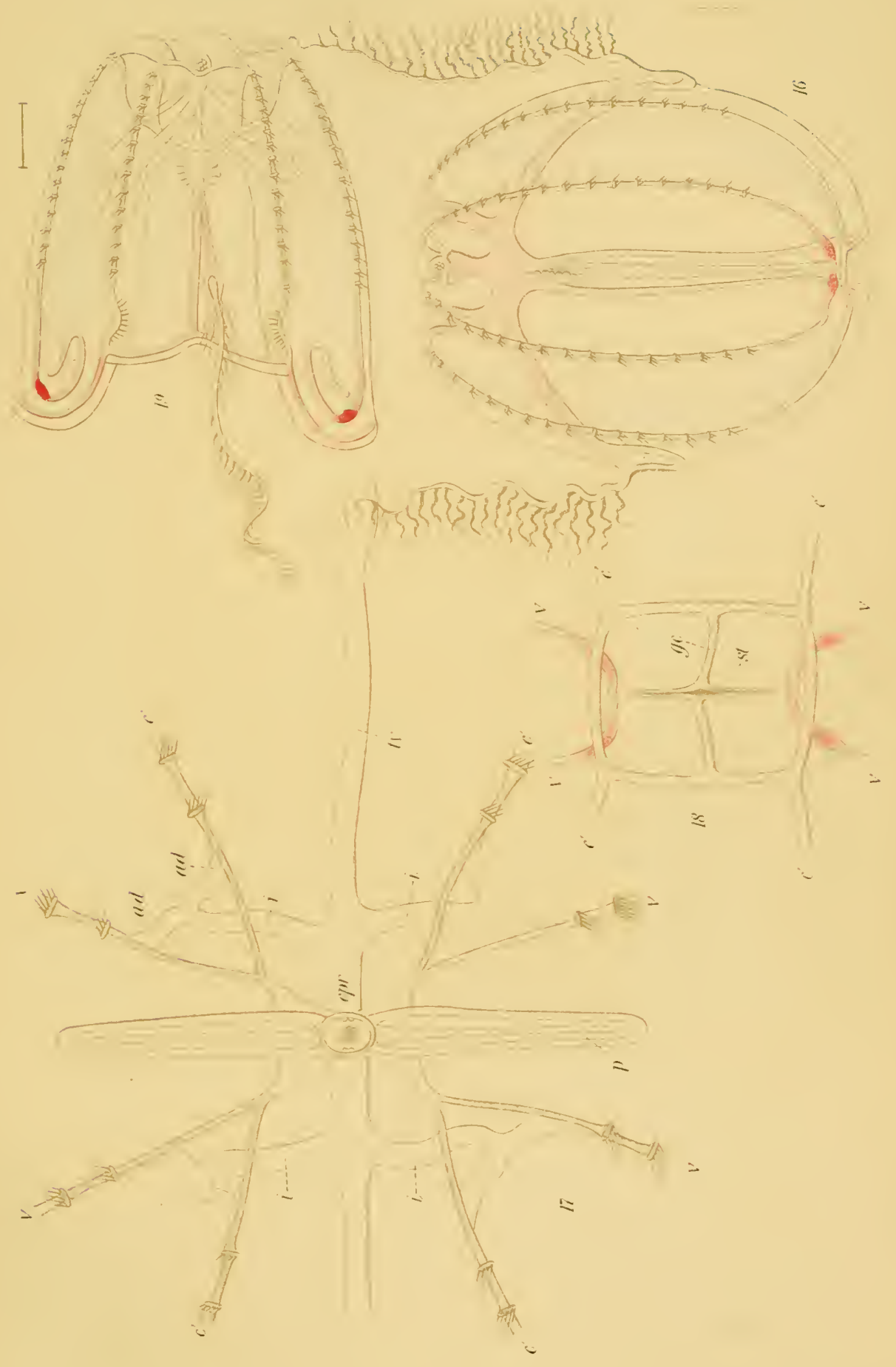



Bolina elegans Mertens, I 833 (Mém. Acad. Sci. St. Pétersbourg, Sci. Math. Phys. et Nat., sér. 6, tome 2, p. 513, Taf. 6, fign. I-4), from the South Seas, is also pink in general color, but the upper parts of the body are covered with numerous small papillæ and these are absent in the Florida species. B. hydatina of Chun is evidently the immature $B$. vitrea from the Mediterranean.

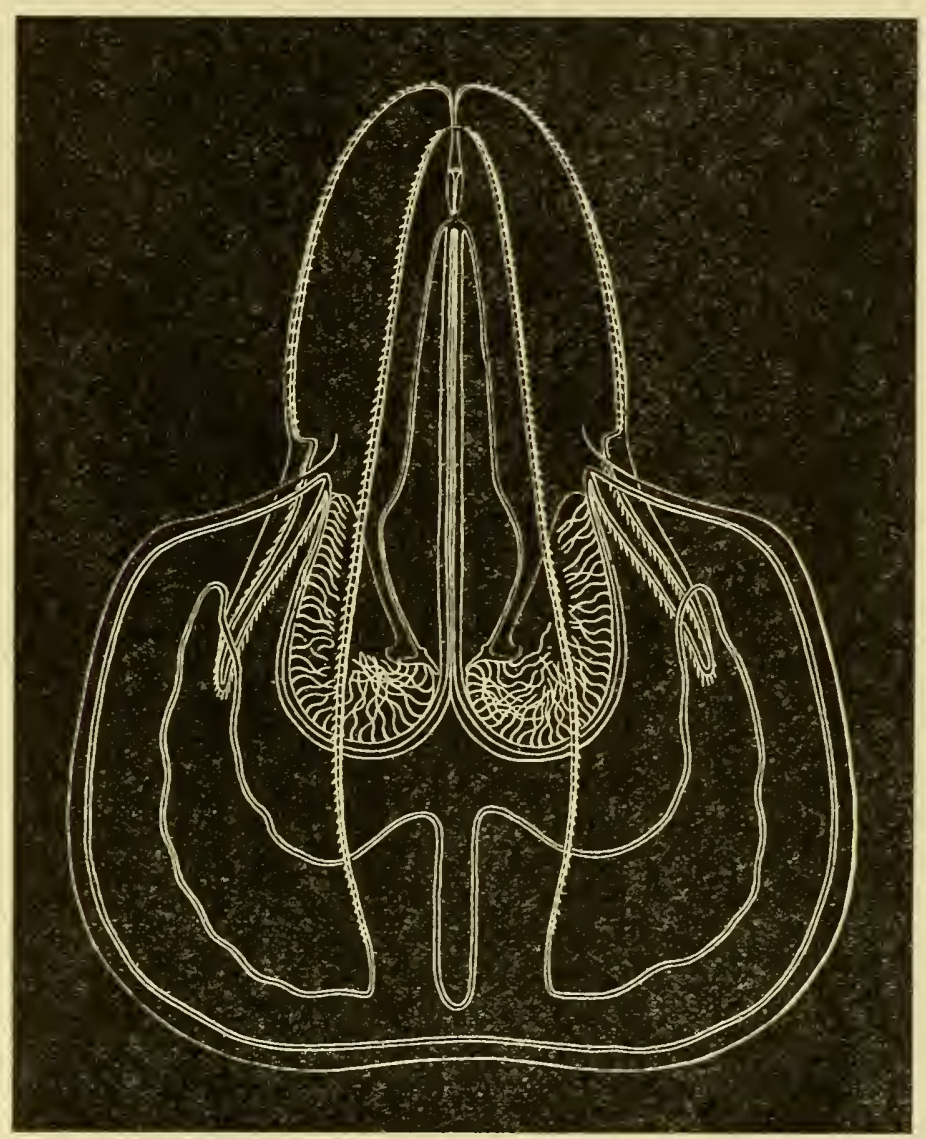

Fı. 7.-Bolinopsis vitrea. Adult, I.25 times natural size. Showing oral lobe expanded, and canals. Tortugas, Florida, June, ig I0. From life, by the author.

A solution of 0.6 molecular sodium chloride inhibits and soon stops the movements of the cilia of $B$. vitrea, but solutions of 0.4 molecular magnesium chloride or molecular magnesium sulphate which are isotonic with the sodium chloride of sea-water have an opposite effect, for they produce an abnormally rapid movement of the cilia, each comb beating independently, and the coördination of the rows of combs being destroyed. In solutions containing potassium in weak concentration the combs stop momentarily and then resume their movement.

This converse relation between ciliary and muscular movement may be explained in the following manner: When the muscles contract, the 
combs of cilia overlying them cease to beat and resume their rhythm only when the muscles relax, for if the surface of the ctenophore be pressed or stretched the ciliated combs of the stretched area are inhibited. Thus magnesium does not stimulate, but weakly subdues ciliary movement; but its inhibitory effect upon nerves and muscles is more marked, and it soon relaxes the muscles, thus lessening the muscular tonus and reducing the pressure which is normally exerted by the epithelium upon the cilia-bearing cells; and then the cilia beat unhindered as do,isolated cells when separated from the epithelium. Thus the so-called "converse relation between ciliary and muscular morement" is due to mechanical causes, not to converse chemical effects of the cations of sea-water upon muscles and cilia respectively.

\section{Genus MNEMIOPSIS L. Agassiz, 1860.}

(?) Alcinoë, Rang, I828, Mem. Soc. d'Hist. Nat. de Paris, tome 4, p. I68.

(?) Mnemia, Eschscholtz, I829, Syst. der Acalephen, p. v, 3 I.

Mnemiopsis, Agassiz, L., I860, Cont. Nat. Hist. U. S., vol. 3, pp. 269, 290.Agassiz, A., I 865, North Amer. Acal., p. I 9.-Chun, I880, Ctenophoren Golfes von Neapel, p. $29 \circ$; also, I 898, Ctenophoren der Plankton-Expedition, p. 25.MAYER, I 900 , Bull. Museum Comp. Zool. at Harvard College, vol. 37, p. 9.Moser, I go8, Abhandl. Akad. München, Suppl. Bd. I, Abhandl. 4, p. 59.

\section{GENERIC CHARACTERS.}

This genus of the Lobatæ is closely allied to Bolinopsis, but is distinguished by having 4 deep, lateral furrows which extend upward from the level of the mouth along the edges of the oral lobes to about the level of the apical sense-organ. A lateral branch from the paragastric vessel extends upward along each of these grooves, and numerous short, simple tentacles arise along the length of this canal. The outer edge of an auricle also extends upward along each groove and this edge is bordered with numerous cilia.

The type species is Mnemiopsis gardeni L. Agassiz, from Charleston, South Carolina.

Future studies will probably demonstrate that Alcinoe vermiculata Rang, $x 8_{28}$, found in April in the entrance to the Bay of Rio Janeiro, Brazil, is identical with Agassiz's genus Mnemiopsis. Certainly it has all of the external characters of Agassiz's genus, but Rang does not figure or describe its internal anatomy, so that there is a possibility that we may be able to separate it generically from Mnemiopsis. Rang's ctenophore was redescribed by Eschscholtz, r 829, under the name Mnemia schweiggeri. Another species from the southern hemisphere in S.lat. $44^{\circ} \mathrm{I}^{\prime}, \mathrm{W}$. long. $56^{\circ} 30^{\prime}$, north of the Falkland Islands, is described and figured by Mertens, I 833 , under the name Alcinoe rosea. I am strongly inclined to believe that Agassiz's Mnemiopsis should be called Alcinoe, but I hesitate to act in the matter owing to our imperfect knowledge of the forms described by Rang, Eschscholtz, and Mertens.

Mnemiopsis leidyi A. Agassiz. (Figs. 20 to 46 , plates 6 to 8.)

Mnemiopsis leidyi, Agassiz, A., 1865, North Amer. Acalephæ, p. 20, figs. 22-24.Fewkes, I88I, Bull. Mus. Comp. Zool. at Harvard Coll., vol. 8, No. 8, p. I 73 , plate 8, figs. I-II; also, Ibid., vol. 9, p. 29I, plate I, figs. I-9.-CHUN, C.. 1898 , Ctenophoren der Plankton-Expedition, p. 25. - HuNter, I904, Biol. Bulletin, Woods Hole, vol. 6, p. 324.-PARkER, I905. Jour. Exper. Zool., vol. 2, p. 407.-Lillie, R. S., I908, Amer. Jour. Physiol., vol. 2 I, p. 200. 
The adult animal (figs. $42,43,46$, plates 7 and 8 ) is about $100 \mathrm{~mm}$. in length, specimens larger than this being rare. When seen from the narrow side, the general outline of the body is almost ellipsoidal. A view of the broad side, however, shows a pear-shaped outline, this being due to the wide-flaring oral lappets. The aboral apex is not so acute as in Bolinopsis infundibulum, and not so blunt as in Lesueuria hyboptera. The

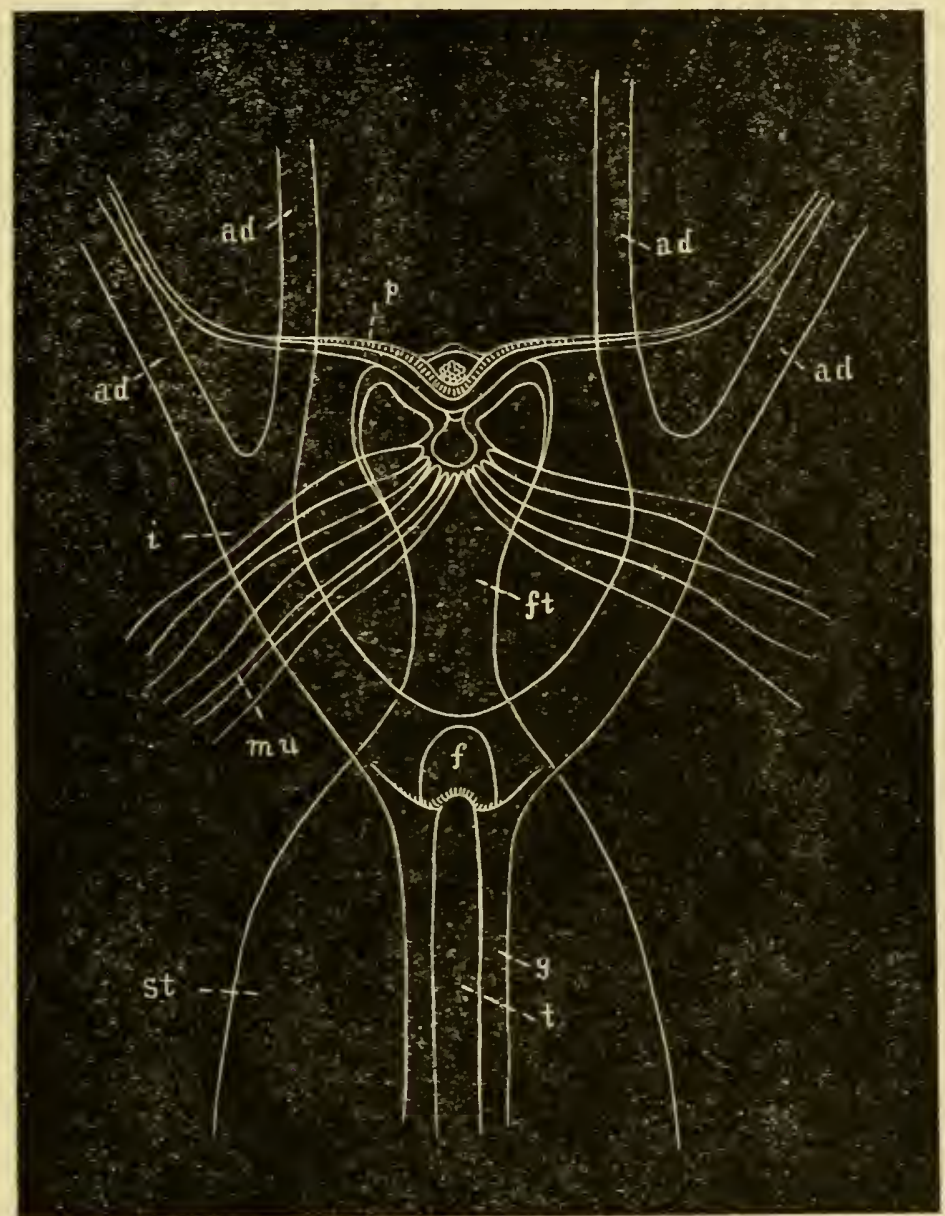

FIG. S.-Sense-organ of Mnemiopsis leidyi. From life, by the author, at Newport, Rhode Island. ad, adradial canals; $c$, cilia at aboral end of stomodæum; $f$, funnel or entodermal center of gastrovascular system; $f t$, axial-funnel canal; $g$, paragastric canal; $i$, interradial canal; $m u$, connective tissue strands; $p$, pole plate; st, stomodæum; $t$, tentacular canal.

apical sense-organ (text-fig. 8) contains a mass of highly refractive concretions, and lies at the bottom of a moderately deep cleft. The oral lappets are each about two-fifths as long as the entire animal and are even wider than they are long. The 4 auricles are flat and ribbon-like, and about one-fourth as long as the body of the animal. Their centrif- 


\section{Plate 6}

Development of Mnemiopsis leidyi. Agassiz Laboratory, Newport, Rhode Island, July 27 to August 4, 1892.

FIG. 20. Newly laid egg.

FIG. 2 r. View of animal pole in a late segmentation stage. About 6 hours after egg is laid.

FIG. 22. Side view of stage slightly older than figure 2 I.

FIG. 23. View of vegetal pole of an embryo about 7 hours old, slightly older than that shown in figure 22 .

FIG. 24. Side view of an embryo about 7 hours old.

FIG. 25. First appearance of ciliary combs in 4 double rows.

Figs. 26 and 27. Median sagittal optical sections to show arrangement of cells. Ectoderm dotted and composed of many small cells, individual cells not being shown in figure. Entoderm cells large and drawn in outline.

Figs. 28 and 29. Development of concretions at aboral pole of embryo. Figure 29 shows the same animal half-hour older than that shown in figure 28 . Note remarkable development of cilia during the interval.

FIGs. 30-32. Oral, aboral, and side views of embryo about 3 hours older than those shown in figures 28 and 29.

FIG. 33. Embryo still within the egg-envelope, about 24 hours old. No tentacles have yet developed.

FIG. 34. Embryo with tentacles, about 30 hours old and still within the egg envelope.

FIG. 35. Newly-hatched embryo about 30 hours old. The animal is now in the Cydippidæ-stage.

FIG. 36. Aboral pole of an embryo about 32 hours old, showing decided lateral compression, the tentacular axis being now the wider, as in Mertensia, although the reverse is the case in the mature animal.

FIG. 37. Side view of an embryo about 32 hours old, showing muscular strands.

Fig. 38. About 36 hours old. View of aboral pole, showing a stage wherein the stomodæal axis has become nearly as wide as the tentacular.

FIg. 39. Young Mnemiopsis leidyi, $5 \mathrm{~mm}$. long. The oral ends of the 2 paragastric canals are now $\perp$-shaped, the 2 meridional ventral canals of each side are fusing at their oral ends. The tentacles are migrating downward toward the mouth and the oral lobes are about to develop.

Drawn from life, by the author. 
CTenophores of the Atlantic Coast of North America

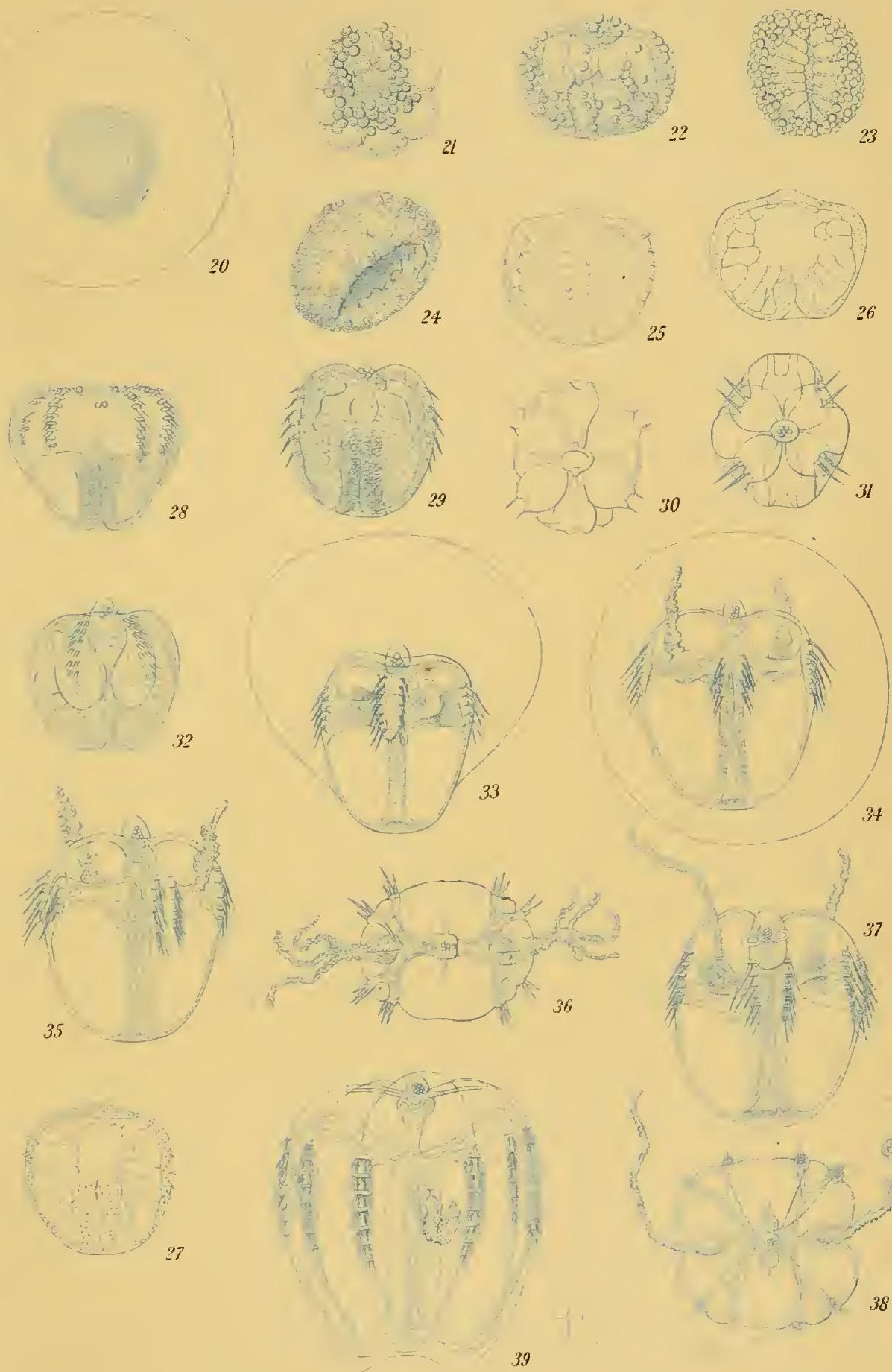

B. Yeisel lith Bosion 

ectoderm, while others lie at first at the lower (oral) pole of the embryo but are carried inward by invagination until they come to lie immediately under the apical sense-organ, where they give rise to the mesoderm. The stomodæum is formed by invaginated ectoderm derived from the original macromeres (figs. 26,27 , plate 6 ). The axial funnel-tube and peripheral chymiferous vessels are of entodermal origin and are formed from the macromeres after the formation of the primitive mesodermal cells. - The body becomes egg-shaped, the aboral pole being broadest. There is considerable lateral compression, the tentacular axis being wider than the sagittal. When the animal is mature, however, the reverse is the case, for then the tentacular diameter is the narrower. The combs of cilia appear as 4 double rows of simple lashes. These soon separate, however, forming 8 rows of ciliated plates. The apical sense-organ is at first situated within a very shallow depression at the aboral pole, but this cleft gradually deepens until the organ becomes sunken deeply within a furrow. When about 30 hours old, the embryo has acquired 4 double rows of cilia, a well-developed pair of lateral tentacles, and a large, apical sense-organ (fig. 34 , plate 6 ). The entodermal part of the gastro-vascular system consists of 6 lateral diverticula from a central chamber; 2 of these lateral branches lead into the bases of the tentacles and the other 4 lead outward toward the 4 double rows of cilia. The ectodermal buccal pouch, or stomodæum, has become a long, laterally compressed tube, with its broad axis $90^{\circ}$ from the tentacular axis of the animal. Until this time the animal swims about quite freely within the egg-envelope, and even in this stage its cilia may be observed to beat in a normal manner and the tentacles to elongate or contract in response to stimuli. Soon after this the larva breaks through the egg-envelope and escapes into the water. Here it goes through stages which are so close to those of the young Pleurobrachia that it is almost impossible to distinguish the embryos of the two species apart. The tentacles acquire numerous lateral filaments and elongate greatly, as in Pleurobrachia. When the animal is $5 \mathrm{~mm}$. long the oral lobes begin to develop as two simple outgrowths on both sides of the mouth in the sagittal plane of the animal (see fig. 39, plate 6). The sagittal diameter is then somewhat longer than the tentacular diameter, and from this time onward the disparity between these two diameters increases at the expense of the tentacular diameter. At the time when the oral lobes begin to develop, the meridional rentral canals and the paragastric tubes begin to elongate downwards (fig. 39, plate 6). The former give rise to the characteristic loops in the oral lobes, while the 2 gastric tubes become $\perp$-shaped at their ends and finally extend up the lateral furrows which lie adjacent to the sides of the lobes, forming a circumoral vessel around the lobes. The 4 meridional vessels extend downward and fuse with the circumoral vessel. The primary tentacle-bulbs migrate downward at the same time and come to lie close by the sides of the mouth, and they carry the tentacular canals down with them. The auricles appear last of all, after the lobes have developed to some extent. When ro $\mathrm{mm}$. in length the animal is ellipsoidal in outline and the condition of the lobes and auricles is similar to that in the adult of Bolinopsis (see fig. 40, plate 7). 
Afterwards the deep, lateral furrows extend upward to the level of the apical sense-organ and the animal acquires the characters of Mnemiopsis. Thus the larvæ pass successively through stages characteristic of Pleurobrachia, then of Bolinopsis, and finally Mnemiopsis.

This species is common throughout the summer off the southern. coast of New England and is also found as far south as the Carolinas. It appears not to occur north of Cape Cod, Massachusetts.

According to Hunter, I904, Mnemiopsis leidyi rests at the surface with its mouth upward, and at the bottom of the aquarium with mouth downward. A constant electrical current of from 0.5 to 3 volts causes it to turn the aboral pole toward the anode and to move toward the cathode. It is relatively more resistant to decrease than to increase in temperature of the water. Responses to electrical stimulation under conditions of greater heat than normal show decrease in reaction time up to about $29^{\circ} \mathrm{C}$., then rapid increase in reaction time. A slow increase in reaction time occurs below $I 5^{\circ} \mathrm{C}$.

Parker, I905, finds that in Mnemiopsis and Pleurobrachia the combs beat metachronally, beginning at the aboral ends of the rows.

In Mnemiopsis the 2 rows of plates belonging to the same quadrant beat in unison. This is often true in Pleurobrachia, although in this form all 8 rows may beat independently.

The propagation wave shows scarcely any evidence of reversal in Mnemiopsis, but often reverses in Pleurobrachia. Reversal of the effective stroke of the plates was never observed in Mnemiopsis or Pleurobrachia.

A transverse cut across a row of combs in Mnemiopsis isolates the oral part of the row, which, however, soon recovers, although it beats independently of other rows. An isolated plate will beat if it retain a small amount of basal protoplasm.

Cooling part of a row to $5^{\circ} \mathrm{C}$. brings the movements of the cooled plates to a standstill, but does not interrupt transmission of the impulse to beat. Stretching of a part of a row also prevents movement, but does not prevent transmission. The transmission impulse is, therefore, mainly if not wholly nervous in nature, although probably supplemented by mechanical transmission from one comb to its neighbor.

R. S. Lillie, Igo8, finds that in Mnemiopsis mechanical stimulation arrests the automatic activity of the swimming plates. This, however, does not occur if calcium be absent, and the effect decreases as the calcium is decreased.

Chun, I880, finds that the litholite concretions of the sense-organs of Ctenophoræ are composed of calcium phosphate, whereas I find that in Scyphomedusæ they consist of calcium oxalate. The functions of the concretions in respect to movement must therefore be quite different in the ctenophoræ and scyphomedusæ.

In this connection it is of interest to state that Samassa, 1892 (Archiv für mikroskop. Anat., Bd. 40), finds that the litholites are not cell products, but are contained within epithelial cells which usually retain their nuclei, and are set free from the epithelium and gathered together in a mass at the apical pole. It will be recalled that Verworn, 



\section{Plate 7.}

Mnemiopsis leidyi. Agassiz Laboratory, Newport, Rhode Island, summer of 1892 .

FIG. 40. Young $M$. leidyi, 10 $\mathrm{mm}$. long with developing oral lobes. and auricles. The embryo is now in the Bolinopsisstage.

Fig. 4I. Sense-organ of the ctenophore shown in figure 40.

Fig. 42. View of broad side of a mature $M$. leidyi. Natural size.

Fig. 43. View of auricular side of a mature M. leidyi. Natural size. Lobes not expanded.

FIG. 44. Half-grown $M$. leidyi; side view, natural size.

Fig. 45. View looking down upon mouth of $M$. leidyi. Natural size. Showing expanded lobes and auricles.

Drawn from life, by the author. 

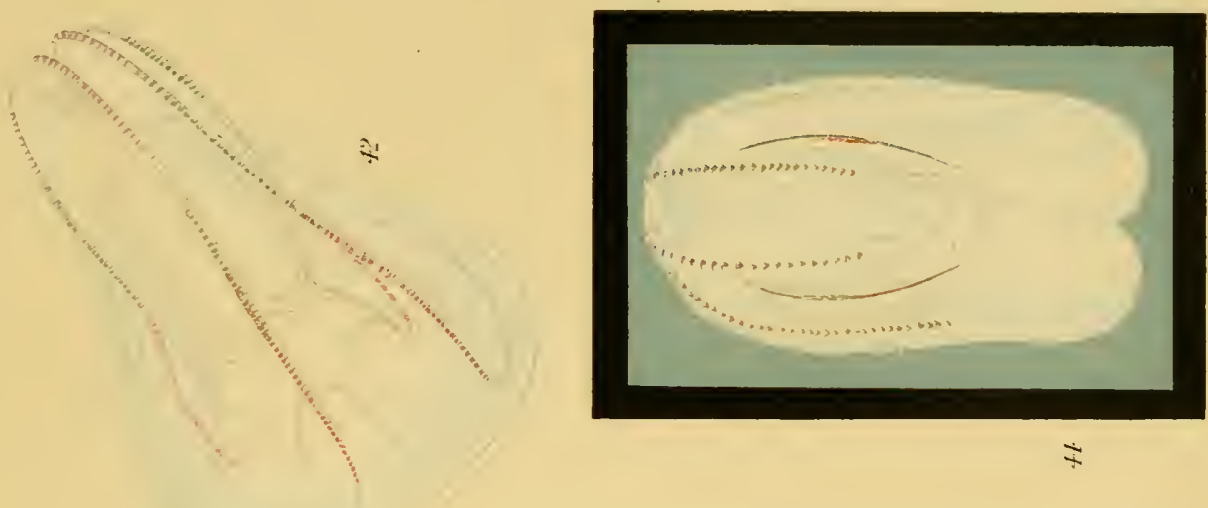

$\Varangle$
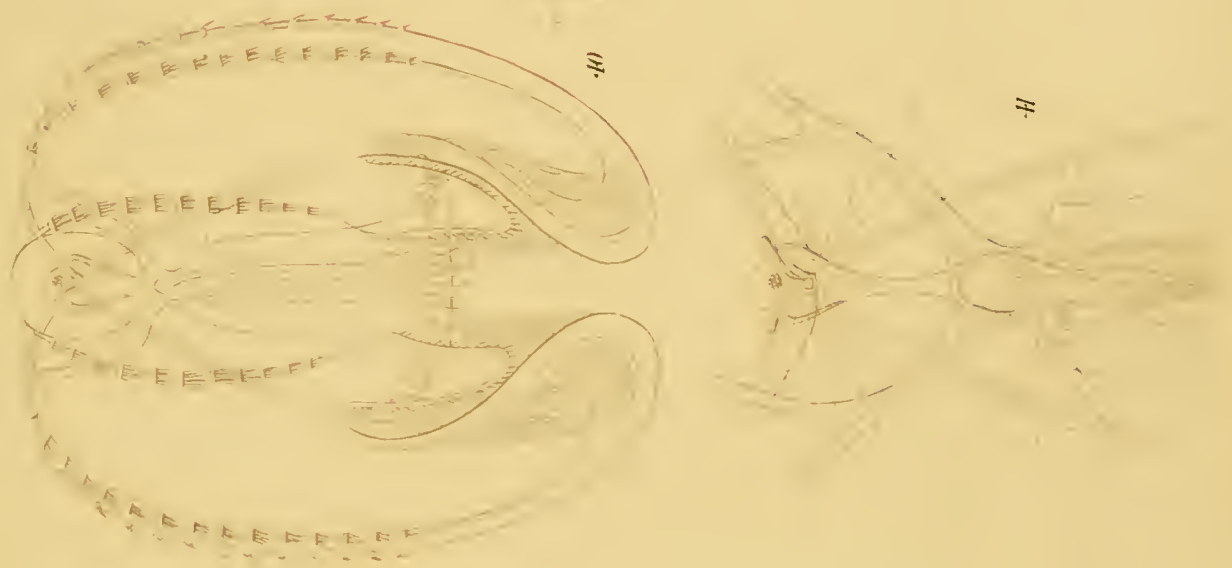

is

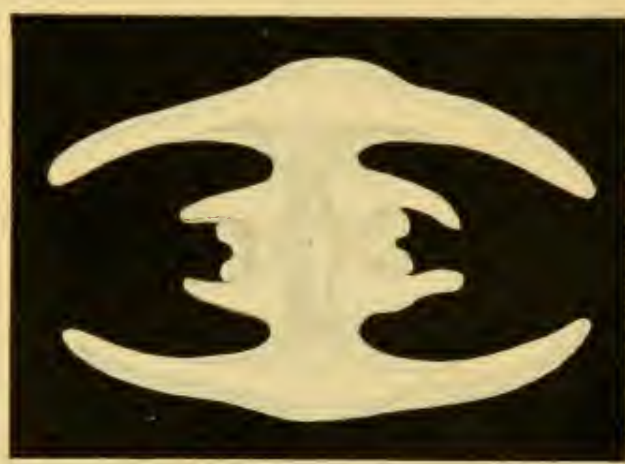

B Meissil lith, Boswn 

I 89 I (Pflüger's Archiv für Physiol., Bd. 50, p. 423), concludes that the apical sense-organ in Beroe does not subserve the sense of hearing, but controls the orientation and equilibration of the animal. Without the sense-organ the animal assumes unnatural positions in the water.

I find that the effective stroke of the cilia of Bolinopsis vitrea may sometimes be reversed by a solution composed of 0.625 molecular (IOO $\mathrm{NaCl}+$ I $1.6 \mathrm{MgCl}_{2}$ ), so that the animal swims backward, i.e., mouth-end forward.

Mnemiopsis mecradyi Mayer. (Fig. 48, plate 8.)

Mnemiopsis mocradyi, MAYer, Igoo, Bull. Museum Comp. Zool. at Harvard College, vol. 37, p. 9, figs. 22,23 , plate 6 .

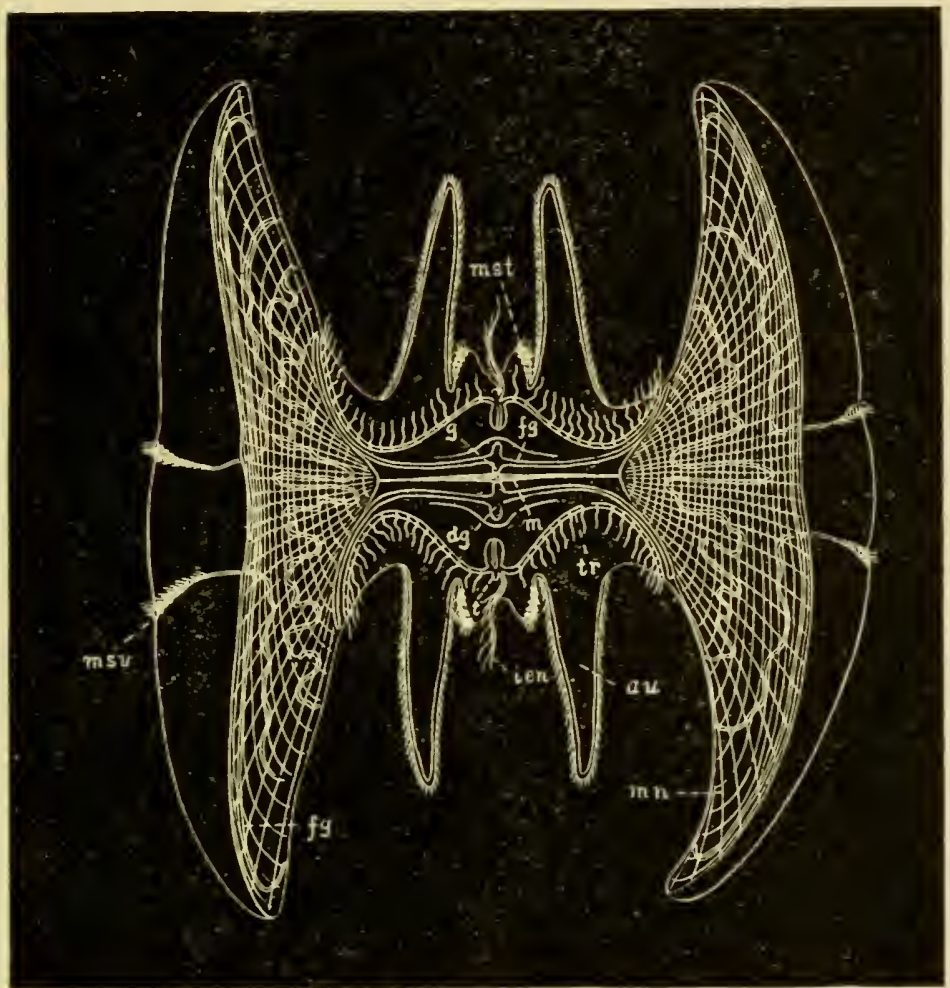

FIG. 9. Mnemiopsis mccradyi, view of mouth, auricles, and oral lobes. $a u$, auricle; $d g$, axial extension of paragastric canal; $f g$, oral forks of the paragastric canals; $g$, paragastric canal; $m$, mouth; $m n$, muscular net in the oral lobes; mst, meridional subtentacular combs; $m s v$, meridional subventral combs; $t$, tentacular canal; ten, axial tentacle; $t r$, tentacular ridge. From life by the author. Port Royal, Jamaica, May, IgII.

The animal is about roo $\mathrm{mm}$. long, and the general form of the body is very similar to that of $M$. leidyi. The lateral compression of the body is, however, more marked, while the gelatinous substance is far more rigid and of a decided greenish-amber color and opalescent not trans- 
parent as in $M$. leidyi. The outer surface, instead of being smooth as in $M$. leidyi, is besprinkled by numerous small warts, which are, however, not found between the subtentacular rows of combs, but are well developed on the sides of the oral lobes. The windings of the meridional ventral canals through the oral lobes are far more complex than in $M$. leidyi, and the canals are of a decided purple color. This is the most rigid ctenophore known. The animal may be removed from the water by hand without suffering injury. The mature ova are similar in form to those of M. leidyi. I first found this ctenophore in Charleston Harbor, South Carolina, late in summer, and again in considerable numbers off Port Fownsend in Kingston Harbor, Jamaica, late in March, I909, and in May, IgII. It is said by local fishermen to be common throughout the summer at Jamaica. It lives well in aquaria, and is doubtless the most favorable form among ctenophoræ for physiological experiments. It is greedily devoured by the scyphomedusa Dactylometra. When 53 $\mathrm{mm}$. long the young animal is of a glassy transparency, and has all the structural features of Mnemiopsis.

The following table gives the dimensions in millimeters of two mature specimens of this ctenophore found off Port Henderson, Kingston Harbor, Jamaica:

\begin{tabular}{|c|c|c|}
\hline & Mar. 22, 1909. & May I, IgII. \\
\hline 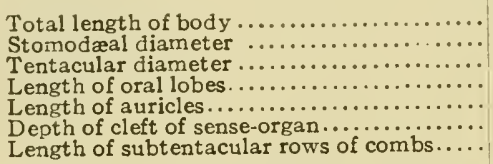 & $\begin{array}{r}108 \\
44 \\
24 \\
39 \\
26 \\
15\end{array}$ & $\begin{array}{l}96 \\
44 \\
34 \\
25 \\
29 \\
15 \\
60\end{array}$ \\
\hline
\end{tabular}

This species is distinguished from $M$. leidyi by the extraordinary rigidity of its gelatinous substance, the complex windings of its meridional ventral canals in the oral lobes, its amber-greenish opalescent color, and the wart-like protuberances over the sides of the oral lobes.

If this ctenophore be placed in 33 parts of sea-water +67 parts of 0.4 molecular magnesium chloride the cilia cease to beat for about 3 minutes, after which waves begin to course with abnormal rapidity down the rows of combs, the movement being coordinated as in natural seawater, but of far greater energy and speed; the stimuli following closely one upon the other so that several waves are commonly traveling down the same row of combs at one and the same instant. This abnormally rapid movement of the cilia continues more than ${ }_{5}$ hours, the muscles during all this time being incapable of contraction.

If, on the contrary, the ctenophore be placed in 33 sea-water +67 parts of 0.625 molecular sodium chloride the rows of combs cease to beat at the end of 12 minutes and the cilia along the auricles at the end of I 9 minutes, while the muscles are highly excited and contract spasmodically more than half an hour. The auricles lack muscles and are almost incapable of contracting. A local contraction of the muscles causes the cilia overlying them to cease beating until the muscles relax. 



\section{Plate 8.}

FIG. 46. Mnemiopsis leidyi. Twice natural size, with fully expanded oral lobes. Agassiz Laboratory, Newport, Rhode Island, September I9, I896.

FIG. 47. Mnemiopsis gardeni. Twice natural size, with fully expanded oral lobes. Core Sound, North Carolina, November I8, I904.

Fig. 48. Mnemiopsis mccradyi. Natural size, lobes not fully expanded. Charleston Harbor, South Carolina.

Drawn from life, by the author. 

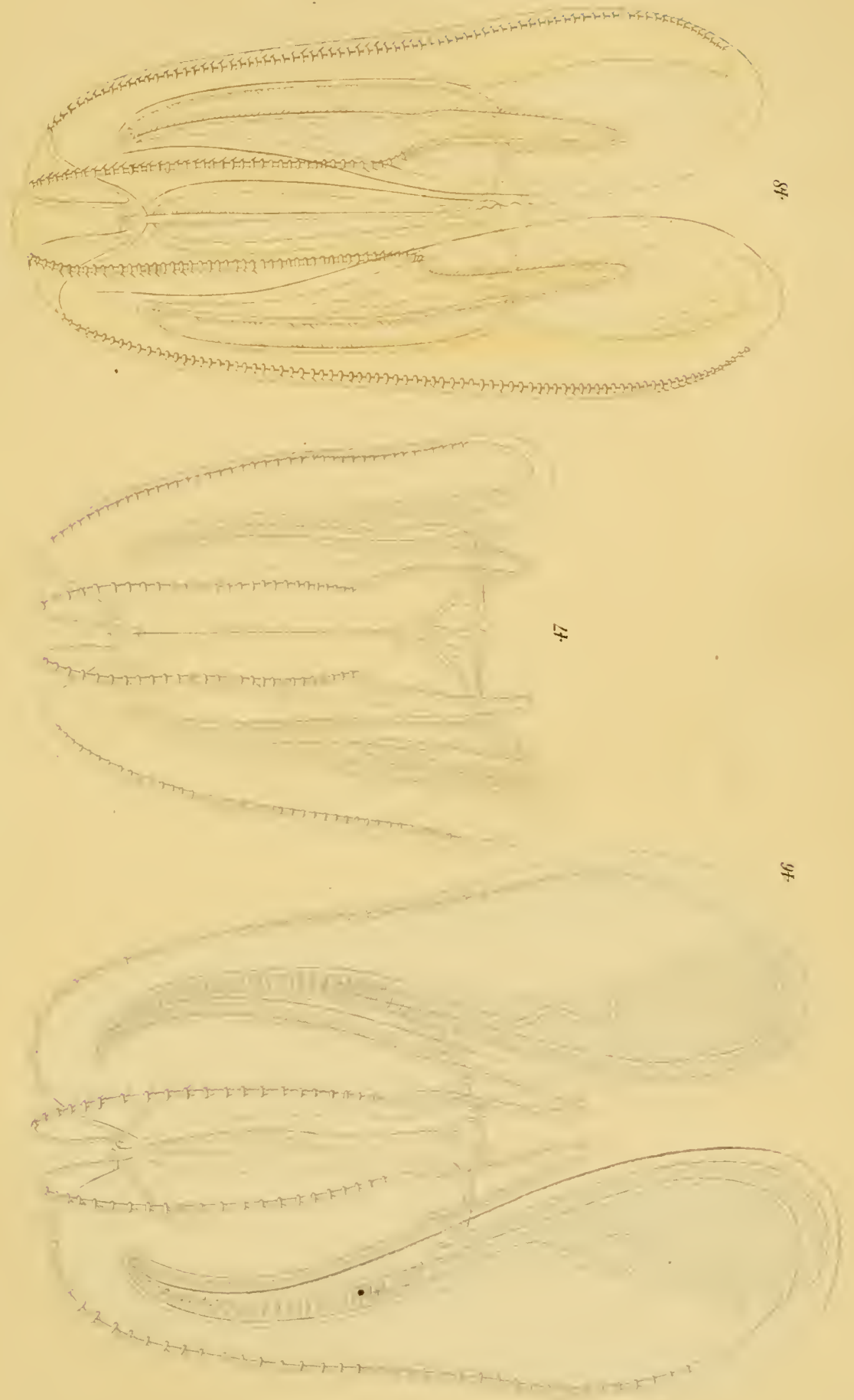

B. Meisel itin. Bostan 

for when the ciliated epithelium is stretched through the contraction of the underlying muscles the cilia are stopped, but if the muscles be relaxed, as by magnesium, the surface tension is reduced and the cilia are free to beat.

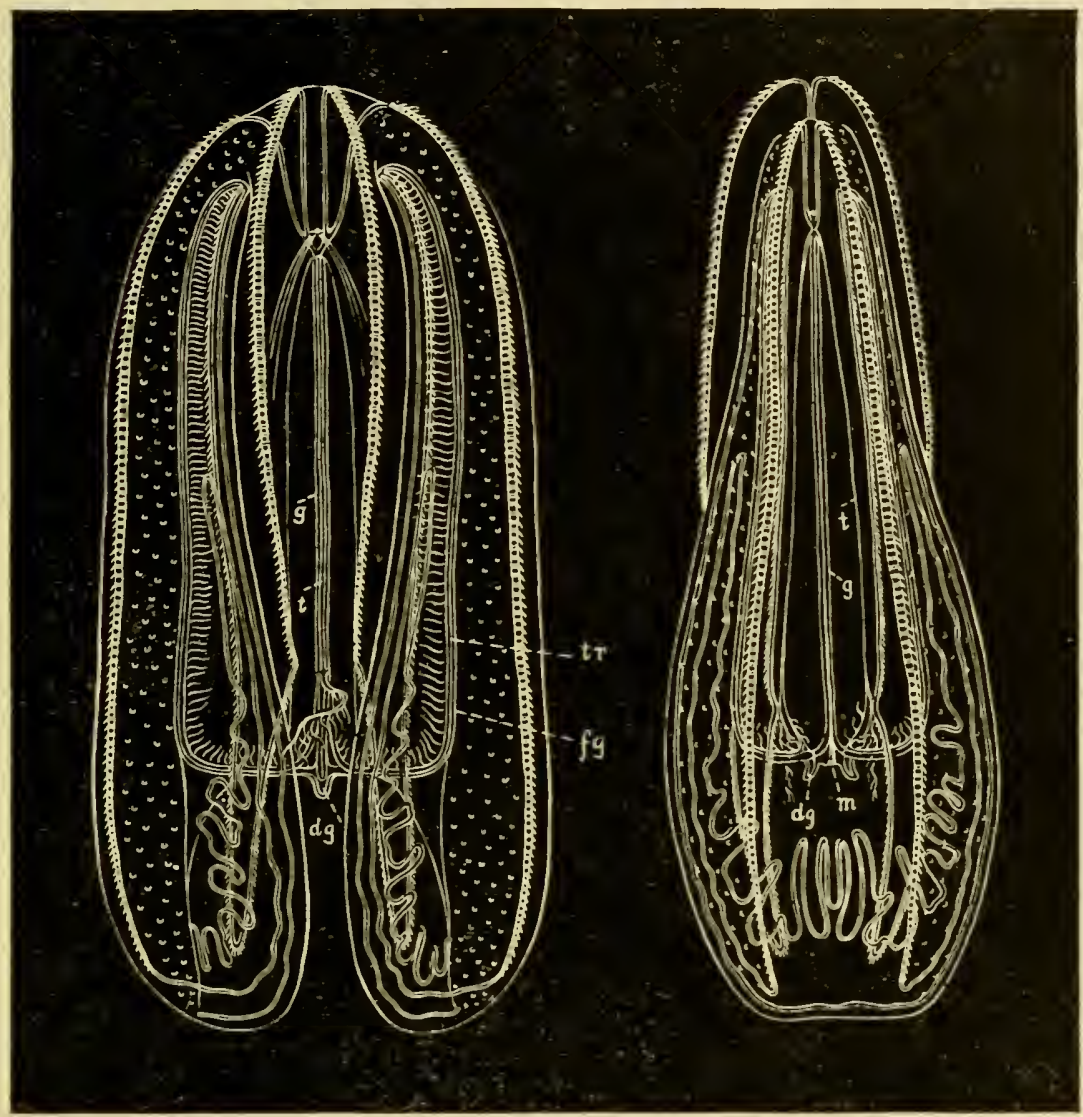

FIG. I0.-Mnemiopsis mccradyi, from life by the author. Natural size. Lettering as in fig. 9. Port Royal, Jamaica, May I, IgII.

Mnemiopsis gardeni L. Agassiz. (Fig. 47, plate 8.)

Mnemiopsis gardeni, Agassiz, L., I860, Cont. Nat. Hist. U. S., vol. 3, pp. 269,290, figs. 95, 96.-Agassiz, A., I 865, North Amer. Acal., p. 20, figs. 20, 21 .-CHUN. C., 1898 , Ctenophoren der Plankton-Exped., p. 25.

(?) Bolina littoralis, MICCRADY, I8 59, Proc. Elliott Soc., Charleston, vol. I, p. 254, plate 14 , figs. I-I 4 (development).

This is a small species, being only 35 to $40 \mathrm{~mm}$. long when mature. The oral lobes are of very small size, being only one-fifth to one-sixth as long as the body of the animal. The auricles, however, are well developed, being relatively about as long as in $M$. leidyi and about one-third as long as the entire body of the animal. There is considerable lateral compression, the sagittal diameter being about 2.5 times as great as the tentacular. The 4 deep lateral furrows extend from the level of the mouth about three-quarters the distance up the sides of the body. They are not as 
long, however, as in $M$. leidyi and do not quite reach to the level of the apical sense-organ. The 4 meridional ventral rows of combs which extend out over the oral lobes are about one-third longer than the 4 rows which lead to the auricles. The meridional ventral rows begin also at a greater distance from the apical sense-organ than do the meridional subtentacular combs. The windings of the meridional ventral canals in the oral lappets are very simple, thus differing markedly from the conditions seen in $M$. leidyi and $M$. mccradyi. The apical sense-organ is sunken within a deep cleft about one-sixth as deep as the total length of the body.

The surface of the oral lobes and the adjacent parts of the body are besprinkled regularly with small, low, discoidal warts. The animal is translucent and slightly bluish in color. It is very abundant along the coast from Chesapeake Bay to Florida, being especially common in bays, sounds, and estuaries where the water is slightly brackish.

I have never seen any intergrading forms between this southern species and the somewhat more northerly $M$. leidyi. $M$. leidyi is a creature of the pure sea-water along the outer shores, while $M$. gardeni thrives in protected bays and brackish waters.

\section{Genus LEUCOTHEA Mertens, 1833 .}

Eucharis, preoccupied by LATREILLE for Hymenoptera in 1804 .

Eucharis, used for Mollusca by PÉRON in 1807 .

Eucharis, Eschscholtz, I 825 , Isis, p. 742; also, I829, Syst. der Akal., p. 31 .ChUn, I880, Ctenophoren des Golfes von Neapel, p. 296. - Agassiz and

MAYer, I 899, Bull. Museum Comp. Zool. at Harvard College, vol. 32, p. I 76.-

Allman, I882, Journal Linnean Soc. London, vol. I6, p. Io3.

Beroë, Quoy et Gaimard, I824, Voyage de l'Uranie, Zool., p. 574 .

Alcione, Delle Chiaje, I829, Mem. Animali senzavert., Napoli, tome 4, p. 7. Ibid., I 84 I, Tav. I 50.

Lencothea, Mertens, i 833 , Mém. Acad. Sci. St. Pétersbourg, Sci. Math. Phys. et Nat., sér. 6, tome 2, p. 499.

Chiaja, Lesson, I 843 , Hist. Zooph. Acal., p. 77.

\section{GENERIC CHARACTERS.}

Lobatæ in which the oral lobes are of large size and contain complexly-winding chymiferous tubes. The auricles are long, thick, and coiled in helices with the cilia extending in a loop up and down one side. The outer surface of the body and lobes are covered with long, conical papillæ. The aboral blind ends of the subtentacular meridional canals are long. The 2 median tentacles are very long; 2 long, blindly ending, pit-like depressions extend inward from above the tentacles nearly to the level of the funnel.

This genus is descended from a Bolinopsis-like ancestor, for it passes through a stage in which it can not be distinguished from Bolinopsis. The large papillæ which cover the external surfaces of the oral lobes and of the body are late in developing and do not appear until the animal has passed through the Bolinopsis stage. In this connection it is interesting to observe that Bolinopsis elegans of Mertens, I833, is covered with small papillæ on the whole outer surface of its body, save only upon the lower parts of the oral lobes.

The name Eucharis is preoccupied, having been used for Hymenoptera by Latreille, I804. Alcinoë of Delle Chiaje, I829, can not be used, 
for Rang, I828, applied it to designate a Mnemiopsis-like ctenophore. Leucothea Mertens, 1833 , is thus the oldest distinctive name applied to the genus.

The genus Leucothea is distinguished from all other Ctenophoræ by the 2 remarkable blindly-ending sacs which form a pair of long narrow pits open to the outer world below and extending inward and upward from above the tentacle-bulbs nearly to the level of the funnel.

The type species is Leucothea multicornis of the Mediterranean. This species is most admirably figured and described by Chun, I880 (Ctenophoren des Golfes von Neapel, pp. 47, I 22, I 43, I 5 I, 242, 296 , Taf. 4,5 and 9), who found that when the water was unusually warm the larvæ just out of the egg and still in the Cydippe-stage produced ripe ova which developed into normal but small embryos, resembling those produced by the adult except that they were only about half the normal size.

Leucothea ochracea sp. nov. (Figs. 49 to 54 , plates 9, 10.)

Eucharis multicornis, Fewkes, I882, Bull. Museum Comp. Zool. at Harvard College, vol. 9, p. 25I, plate 7 , figs. I I, I 2.

This Florida species differs from the Mediterranean Leucothea multicornis in its smaller size and simpler windings of the meridional ventral canals through the oral lobes, and by having 4 prominent, yellow areas, a pair in the gelatinous substance of the outer sides of each lobe; but it is chiefly distinguished by having simple, lateral filaments upon its principal tentacles, these being absent in the Mediterranean species.

It will be remembered that Chun, I880, found that the larva of the Mediterranean Leucothea passes through a Cydippe-like stage wherein it has a pair of tentacles provided with lateral filaments as in Mertensia or Pleurobrachia. Later the larva passes into a medusiform stage, in which it completely loses its tentacles, and next it passes into a Bolinopsis stage in which the tentacles reappear, but without lateral filaments. The Leucothea stage then ensues, wherein the papillæ develop over the surface of the body and the blind sacs sink inward into the sides of the body above the bases of the 2 principal tentacles.

I have seen Leucothea multicornis in considerable numbers at Naples, and have never observed lateral filaments upon the tentacles of the adult, nor does Chun mention or figure them in his superb monograph. Their constant presence in the Tortugas ctenophore may therefore be considered as of specific significance. Also I have never seen yellow areas on the sides of the oral lobes in the Mediterranean Leucothea nor does anyone figure them, but these are very characteristic of the Florida Leucothea ochracea and render it a conspicuous object as it floats in the water.

The dimensions of the Florida L. ochracea as compared with those of the Mediterranean L. multicornis are here given in millimeters. The dimensions of the Mediterranean ctenophore are taken from a specimen studied by me at Naples on December 8, 1907. According to Chun, however, the Mediterranean Leucothea becomes about $200 \mathrm{~mm}$. long and $240 \mathrm{~mm}$. across the oral lobes, thus becoming much larger than the 
Florida form. I here give the dimensions of a small specimen from Naples, because it corresponds more nearly in size to those found at Tortugas.

\begin{tabular}{|c|c|c|}
\hline & $\begin{array}{l}\text { Leucothea ochracea } \\
\text { from Tortugas. }\end{array}$ & $\begin{array}{l}\text { Leucothea } \\
\text { multicornis } \\
\text { from Naples. }\end{array}$ \\
\hline 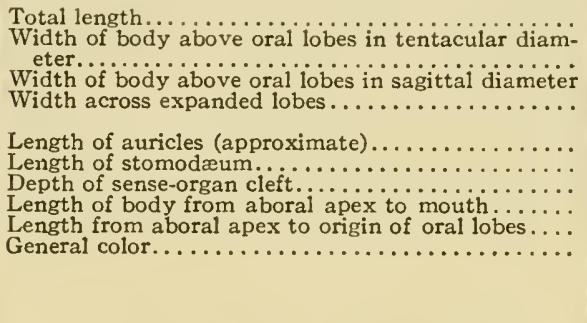 & \begin{tabular}{|l}
96 \\
20 \\
33 \\
I I \\
40 \\
44 \\
10 \\
58 \\
39 \\
Transparent with 4 \\
yellow spots upon \\
oral lobes.
\end{tabular} & $\begin{array}{c}88 \\
26 \\
4 \text { I } \\
\text { 85 not fully } \\
\text { expanded. } \\
\ldots \\
\ldots \\
16 \\
72 \\
45 \\
\text { Dull translucent } \\
\text { brownish without } \\
\text { yellow spots on } \\
\text { oral lobes. }\end{array}$ \\
\hline
\end{tabular}

It is somewhat surprising to find these marked differences between the Mediterranean and the Tortugas forms of Leucothea, for it has long been known that the Mediterranean form is widely spread over the warm parts of the Eastern Atlantic and has been recorded from the Canaries, Azores, and South Equatorial Stream. Fewkes, I882, observed the Florida Leucothea and states that it is more transparent than the Mediterranean form. This statement is true if we except the 4 opaque yellow spots in the gelatinous substance of its oral lobes, which in so far as I have observed appear always to be present.

The Florida species is not common and comes to the surface in numbers only when the ocean is unrippled after days of calm. The least ibreeze suffices to produce sufficient rippling to cause it to sink into the depths. In this habit it resembles Leucothea grandiformis of the Fiji Islands. The Fijian form is, however, anatomically speaking, more nearly allied to the Mediterranean species. It is remarkable that the Mediterranean Leucothea appears to be far less troubled by waves and is often found quite near the surface in fairly rough weather. The extreme tenuity of this Florida ctenophore is remarkable, for even a gentle current suffices to tear it apart. I have seen it only in spring and summer at Tortugas.

But little stress should be laid upon the presence of the 4 yellow areas upon the lobes of the Tortugas Leucothea and we may neglect it as a specific character; for it is possible that this yellow coloration may be due to commensal plant-cells. Unfortunately since this point occurred to me I have been unable to find any specimens of the ctenophore. Indeed, Fewkes appears to have found specimens of Leucothea in Florida waters which lacked these yellow areas and were quite transparent. Some specimens of Folia at Tortugas have yellow spots at the ends of the long axis of the body, while others are wholly transparent. In Cestum amphitrites from the Pacific there are, according to the figures of Mertens, I833, and Bigelow, I904, yellow spots at the tips of the long axis of the body. (See Cestum pectenalis, Bigelow, r 904, Bull. Museum Comp. Zool. 



\section{Plate 9.}

Fig. 49. Lencothea ochracea, sp. nov., I.5 times natural size. Tortugas, Florida, July 3, I906.

Drawn from life, by the author. 


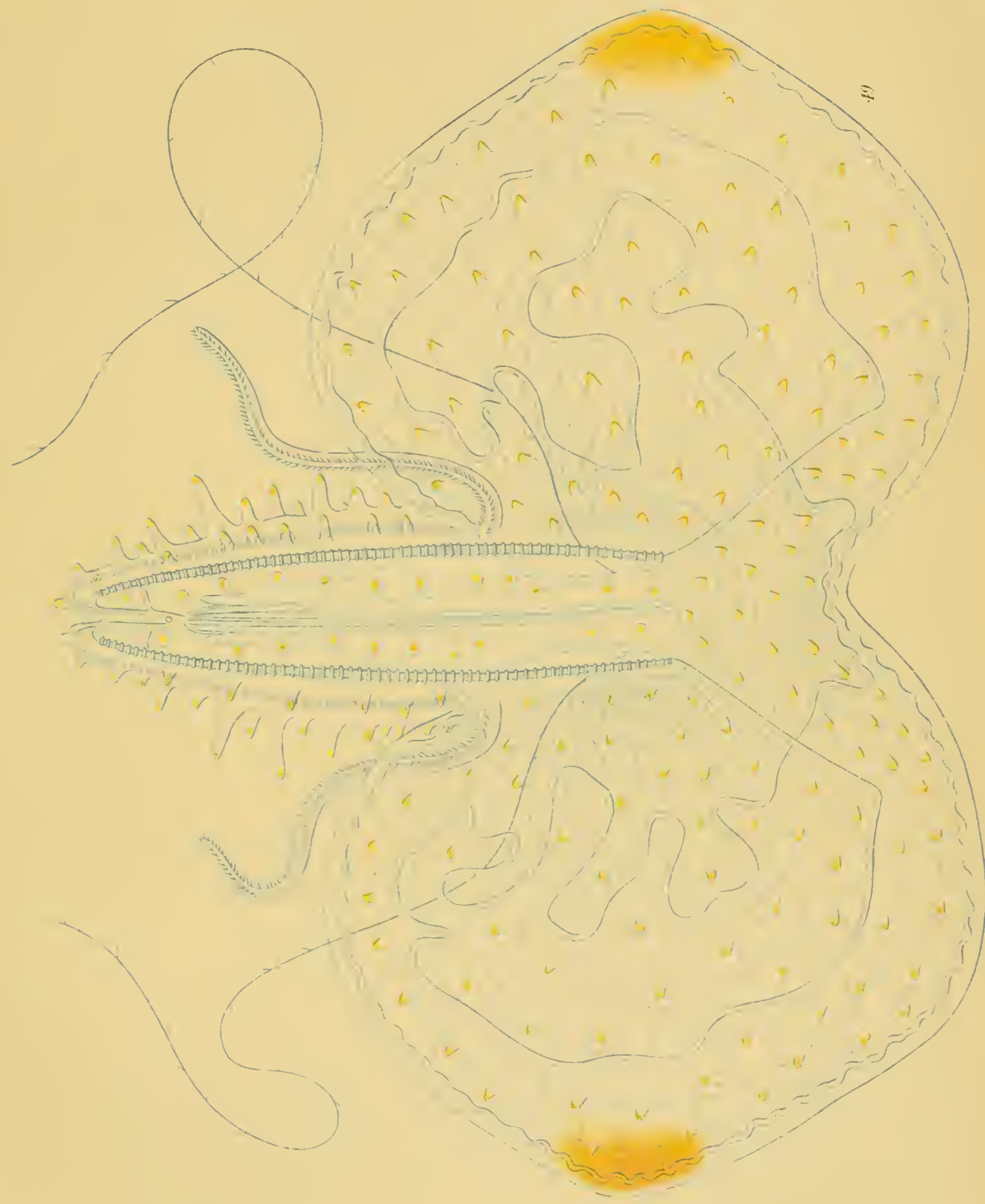



at Harvard College, vol. 39, p. 267 , plate 8, fig. 30.) Also Chun, I 880 (Ctenophoren des Golfes von Neapel, p. 242), found yellowish-green parasitic cells of algæ in the meridional canals of Euchlora which resemble the yellow cells of Radiolaria.

The histologic structure of the papillæ of Lencothea is described by R. Hertwig, I880, Jena. Zeit. für Naturw., Bd. I 4, p. 334, Taf. 2 I, Fig. 3.

\section{Genus OCYROPSIS (nom. nov.).}

Ocyroē, preoccupied in 1809 , for medusæ by PÉRON and LESUEUR.

Ocyroè, RANG, I 828 , Mém. Soc. Nat. Paris, tome 4, p. I 72,-Lesson, I 836 , Annales des Sci. Nat., sér. 2, tome 5, p. 250.-Fewkes, 1882 , Bull. Museum Comp. Zool. at Harvard College, vol. 7, p. 252.-CHUN, I880, Ctenophoren des Golfes von Neapel, p. 290.-Moser, I903, Ctenophoren der Siboga-Expedition, p. I7, also, 1908, Abhandl. Akad. München, Suppl. Bd. I, Abhandl. 4, p. 65.

Calymma, Eschscholtz, I829, Syst. der Acalephen, p. 33.-Mertens, I833, Mém Acad. Sci. St. Pétersbourg, Sci. Math. Phys. et Nat., sér. 6, tome 2, p. 508. Calymma, preoccupied in I8I6 for Lepidoptera by HÜBNER.

\section{GENERIC CHARACTERS.}

Lobatæ with body laterally compressed in the funnel-diameter and with large, muscular oral lappets. These lappets arise from the sides of the body in the stomodæal axis, and it is mainly by means of their contractions that the animal is enabled to swim. The ciliated combs are not very numerous and in the young animal they tend to lie parallel with the meridional canals, as in Cestum. In the adult, however, they usually lie diagonally across the canal. The auricles are well developed and arise from the body near the sides of the oral lappets. There are no tentacles in the adult and no tentacular canals.

Three species, O.crystallina, O. maculata, and $O$. fusca are described by Rang from the tropical Atlantic. O.crystallina is transparent; O. fusca uniform dull brown, and $O$. maculata has 2 large, conspicuous, brown spots on each oral lobe. Eschscholtz, I829, describes a form of Ocyropsis from the Equatorial Pacific under the name Calymma trevirani.

Ocyropsis bears some resemblance to Deiopea of the Mediterranean, but the oral lobes of Deiopea are smaller and the two meridional ventral vessels in each lobe end blindly, whereas they form a closed circuit in Ocyropsis. Also Deiopea has tentacles, and these are absent in Ocyropsis, wherein there are neither tentacles nor tentacular canals.

The genus is found only in the tropics, being represented in both the Atlantic and the Pacific.

Unfortunately, the old and well-known generic name Ocyroe can not be retained for Ctenophoræ, for it was applied to a medusa by Péron and Lesueur, I 809 (Annales du Museum, Hist. Nat., Paris, tome I 4, p. 354). The name Calymma given to this ctenophore by Eschscholtz, 1829, is also preoccupied, having been used by Hübner for Lepidoptera in I 8 I6. While we must all regret the abandonment of long-used and familiar generic names, yet the law of priority, which the zoologists of the world have in congress assembled given their pledge to support, obliges us to revert to the oldest distinctive name; and as preoccupied names must be abandoned, no matter how familiar to us in association, it is expedient that the operation of changing them be executed at once. In place of Ocyroe I propose the new name Ocyropsis. 


\section{Ocyropsis crystallina. (Figs. 55,56 , plate 10.)}

Ocyroè crystallina, RANG, I 828 , Mém. Soc. Nat. Paris, tome 4, p. I 72 , plate 20 , fig. 4.-FEWKES, 1882, Bull. Mus. Comp. Zool. at Harvard College, vol. 9, No. 7 , p. 252 , plate I, figs. I-6.-MAYER, I 900 , Ibid., vol. 37, p. 8I, plate $3 \mathrm{I}$, fig. IO5.-MOSER, I 903 , Ctenophoren der Siboga-Expedition, p. I7.

Mature animal: (Text-figure II.) The oral-aboral axis is about $45 \mathrm{~mm}$. long, and this is also the length of each oral lobe. The body is laterally compressed, the width in the direction of the oral lobes being about three times as great as that of the transverse axis. The 8 rows of ciliated plates are short and the plates are few in number. The 4 subtentacular rows are only about two-thirds as long as the 4 subventral rows. Each subauricular row contains about 20 and each subventral row

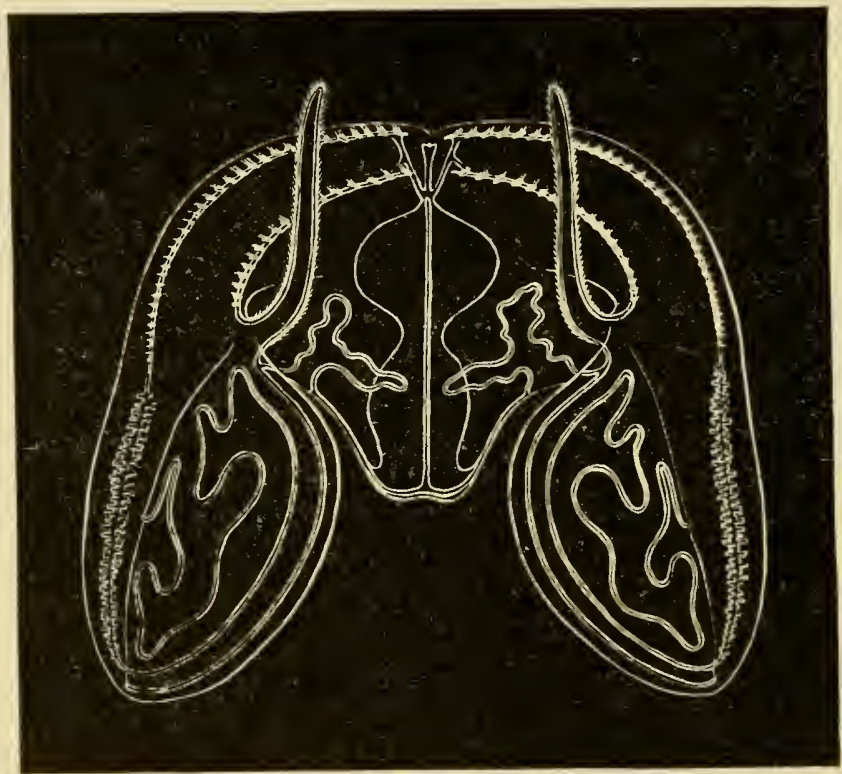

FIG. I I.-Ocyropsis crystallina. Adult, $\frac{1}{5}$ natural size. Tortugas, Florida.

about 40 ciliary plates. The cilia contribute but little to aid the animal in swimming, this being accomplished almost entirely by the flapping movements of the large, powerful, oral lobes, which by their periodic closure drive the animal forward. After two or three closures of the distended lobes there is usually a brief period of rest, followed by several more movements. A powerful system of radiating and circular muscles is found in the oral lobes and the flapping movements are caused by their contraction and expansion. The lobes are I.5 times as wide as they are long. The simple apical sense-organ is sunken at the bottom of a shallow cleft. The auricles are each about $30 \mathrm{~mm}$. in length, flat, and ribbonlike. Their narrow edges are lined with long cilia. Upon the outer surface of the oral lobes, immediately over the longitudinal meridional 

Plate io.

Fig. 50. Leucothea ochracea. One of the auricles.

FIG. 5I. Leucothea ochracea. One of the papillæ.

FIg. 52. Leucothea ochracea. View of sense-organ.

FIG. 53. Leucothea ochracea. Portion of one of the rows of combs, showing follicles of sexual organs and transverse muscles between each pair of combs.

FIG. 54. Leucothea ochracea. Portion of muscular net of oral lobes. FIG. 55. Ocyropsis crystallina. Young animal, $8.5 \mathrm{~mm}$. wide.

FIG. 56. Ocyropsis crystallina. Half-grown Ctenophore, $26 \mathrm{~mm}$. wide. $g$, paragastric canal.

Drawn from life, by the author. 
CTENophores of the AtLANtig Coast of NorTh America

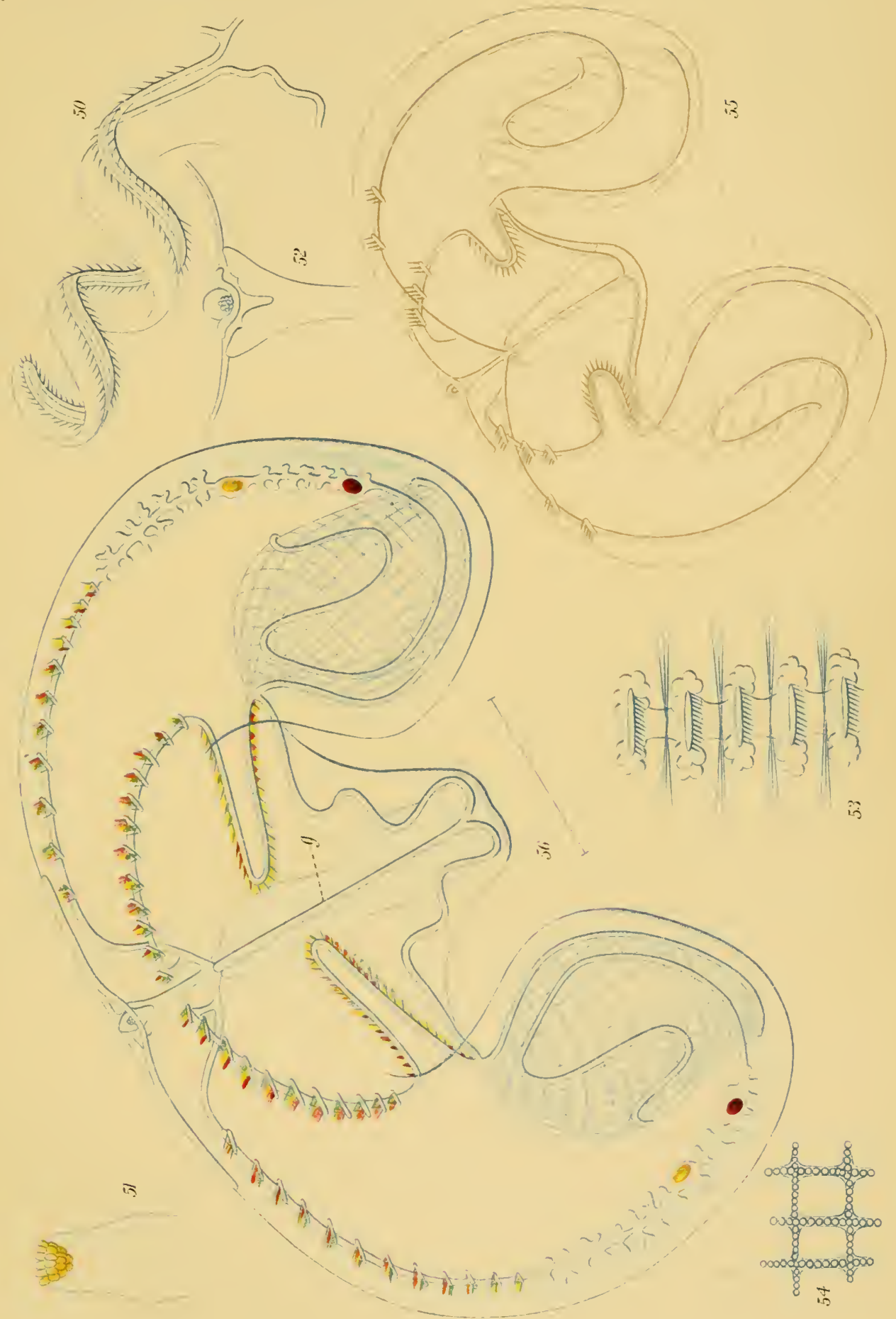

B Mersel lith. Boston. 

canals, there are numerous wart-like protuberances, under which lie diverticula of the canals. The lateral branches of the paragastric tubes give rise to complex windings near the inner sides of the auricles, and the meridional ventral tubes wind complexly in the oral lappets, forming complete circuits. The stomodæum is flat and its broad side is constricted near the middle. The axial funnel-tube is only about oneeighth as long as the stomodæum and the meridional canals are of fine caliber. There are no tentacles and no tentacular vessels. The animal is of a milky translucent hue, the wart-like protuberances on the oral lobes being milky-white in color.

Young animal: When the broad, lateral diameter is $8.5 \mathrm{~mm}$. (fig. 55, plate Io) the creature has assumed all the essential characters of the adult except that the meridional ventral canals give rise to a simple loop in the oral lobes and the lateral branches of the paragastric tubes lead straight into the auricles and do not wind on the way, as in the adult. There are neither tentacles nor tentacular canals. The auricles are mere short, flat protuberances. The meridional ventral rows of cilia consist of only 2 combs each, while the 4 auricular rows contain 3 combs each. The simple capsule of the apical sense-organ lies upon the surface and is not sunken within a groove, as in the adult. A long, narrow pole-plate extends out on both sides of the sense-organ. At this stage the animal moves its oral lobes with great strength and agility and swims with considerable rapidity.

When the Ocyropsis is $26 \mathrm{~mm}$. in its broad, lateral diameter (fig. 56, plate Io) there are I to I 2 combs of cilia in each subventral and the same number in each auricular row. The lateral, blind branches of the subventral canals in the lobes have appeared. The stomodæum is beginning to be constricted in the middle as in the adult, and the canalsystem begins to assume the characteristic windings.

One often observes yellow or brownish-purple masses in the canals of this ctenophore, especially in the blind side branches from the meridional ventral vessels. These masses move about more or less in the currents of the canal-system and disappear after the animal has been captive, and unfed, in an aquarium for a day or two. I am inclined to regard them as products of digestion or of excretion.

This ctenophore is capricious in its appearance, but in some years it is quite common at Tortugas, Florida, swimming in swarms near the surface in spring and early summer on calm days, and sinking when the sea becomes rippled.

O. crystallina is widely distributed over the tropical Atlantic, and it is represented in the tropical Pacific by a closely allied variety with shorter auricles and longer oral lobes, which has recently been described by Bigelow, 1904, as O. ptercessa.

Rang's Ocyropsis fusca is a uniformly light brownish or ochercolored form from the Cape Verde Islands. It has not been seen since Rang described it in 1828 . It is possible that this may be an O. crystallina infested with commensal plant-cells, for such cells often infest the ctenophores of warm or tropical oceans, although they are unknown in species inhabiting cold seas. 


\section{Ocyropsis maculata.}

Ocyroe tachee, RANG, 1828 , Mém. Soc. d. Hist. Nat. de Paris, tome 4, p. 318 , planche 20, figs. I, 2, called $O$. maculata in the plate.

Ocyroé maculata, LEsson, I843, Hist. Zooph. Acal., p. 99.-AGAssiz, A., I865, North Amer. Acal., p. 25.-Few Kes, J. W., I88I, Bull. Mus. Comp. Zool. at Harvard College, vol. 8, p. I37, plate 4, figs. I-4.-AGAssiz, A., I888, Bull. Mus. Comp. Zool. at Harvard College, vol. I 5, p. I 29, fig. 423.-Chun, C., I 898 , Ctenophoren der Plankton-Expedition, p. 25.-MOSER, I903, Ctenophoren der Siboga-Expedition, p. 18, I908, Abhandl. Akad. München, Suppl. Bd. I, Abhandl. 4 , p. 66.

Calymma trevirani, Eschscholtz, I829, Syst. der Acalephen, p. 33, Taf. 2, fig. 5.MERTENS, I833, Mém. Acad. Sci. St. Pétersbourg, Sci. Math. Phys. et Nat., sér. 6, tome 2, p. 508, Taf. 5, Fign. I-3.

Ocyroé crystallina, FEWKES, I882, Bull. Mus. Comp. Zool. at Harvard College, vol. 9, p. $28 \mathrm{r}$.

We have no adequate account of this form. It appears to resemble O. crystallina, but there are 4 large, brownish spots in the muscular network on the inner sides of the oral lobes. These 4 spots render the animal very conspicuous. In other respects it appears to resemble 0 . crystallina. It is said to be widely distributed over the tropical Atlantic, having been found by Mertens off the African coast and by A. Agassiz at St. Vincent, West Indies. It has not been seen at Tortugas, Florida, where $O$. crystallina is sometimes abundant. Moser records it from Japan. It would be unprofitable to quote from the inadequate descriptions of this ctenophore. A careful study of the animal is greatly to be desired.

Moser, I908, who studied only preserved specimens, states that the oral lobes of $O$. crystallina are evenly rounded, whereas those of $O$. maculata terminate in two points. Moser also states that she finds a small tentacle in $O$. maculata, but this requires confirmation, for no other observer has seen tentacles in Ocyropsis, and I am inclined to suspect that she may have had some species of Deiopea.

\section{Genus EURHAMPHAA Gegenbaur, 1856 .}

Eurhamphcea, GegenbaUR, I856, Archiv für Naturgesch., Jahrg. 22, p. 193.-FoL, I 869, Beitrag Anat. und Entwick. der Rippenquallen, Berlin, p. I. - CHUN, r880, Ctenophoren des Golfes von Neapel, Pp. 290, 295.-Jonescu, Igo8, Jena. Zeit für Naturw., Bd. 43, P. 685.

Mnemia, SARS, I859, Nyt. Magazin for Naturvidensk., Bd. Io, p. 70.

\section{GENERIC CHARACTERS.}

Lobatæ in which 2 thick, aboral, gelatinous, subconical projections of the auriculo-tentacular sides of the animal extend upward on both sides of the apical sense-organ, and each gives rise at its pointed aboral end to a simple, flexible tentacle. The 4 meridional subtentacular canals and their ciliary combs extend upward over these projections to their pointed ends. Numerous excretory pores containing a red fluid alternate with the combs of cilia and are regularly arranged along the courses of the 8 meridional canals.

The type species is Eurhamphea vexilligera Gegenbaur, of the Mediterranean and tropical Atlantic, distinguished by its brilliant red fluorescent, probably defensive, substance which is cast out with remarkable suddenness if the animal be disturbed. 


\section{Eurhamphæa vexilligera Gegenbaur. (Figs. 57 to 59, plate I1.)}

Eurhamphaa vexilligera, GEgENBAUR, 1856, Archiv für Naturgesch., Jahrg. 22, p. 193, Taf. 7, Fign. 1-4.-FoL, 1869, Anat. und Entwick. der Rippenquallen, Berlin, p. I, Taf. I, 2.-CHUN, I 880, Ctenophoren des Golfes von Neapel, p. 295.-Jonescu, Igo8, Jena. Zeit. für Naturwissen., Bd. 43, p. 685, Taf. 24, Fign. I-2.-Moser, Igo8, Abhandl. Akad. München, Suppl. Bd., I, Abhand1. 4, P. 69 .

The Eurhamphcea from Florida appears to be identical with that of the Mediterranean. Specimens $50 \mathrm{~mm}$. long have occasionally been found on calm days near the surface at Tortugas in May but most of them are somewhat smaller than this. The dimensions in millimeters of an average specimen found at Tortugas, Florida, on May 15, I906, and figured in the plate, are as follows: total length, 39 ; sagittal diameter, I 7 t tentacular diameter, 9.5 ; length from aboral apex to base of auricles, 26. Gegenbaur's specimens from Messina appear to have been larger than those we have thus far found in Florida, being 75 to $85 \mathrm{~mm}$. long.

The body is elongated, narrow, and with considerable compression in the tentacular axis. The aboral apex is drawn out in the form of 2 gelatinous, horn-shaped processes which flank the apical sense-organ in the tentacular diameter, causing the sense-organ to be sunken at the bottom of a very deep, narrow cleft. These apical processes give rise, at their pointed upper ends, to a pair of very delicate, flexible, tapering, simple filaments, each about one-third as long as the body of the ctenophore.

The 4 subtentacular rows of combs extend upward to the tips of the 2 apical horns and the sensory tracts from the apical sense-organ extend upward along the inner side of each aboral horn to meet them. The 4 subventral rows arise at a much lower level than the 4 others, and commence at the level of the cleft of the apical sense-organ. The subtentacular rows of combs are about two-thirds as long as the body of the animal, while the subventral rows are only a little more than half as long as the total length of the ctenophore. There are about $30 \mathrm{combs}$ in each row. The auricles are one-seventh the length of the animal, and are short, stiff, and stout, with the line of cilia extending in a loop up and down the inner side, as in Leucothea. The oral lobes are also very short, being only about one-fourth as long as the length of the body. The cleft, at the bottom of which the apical sense-organ is placed, is nearly onefourth as deep as the length of the entire animal. The sensory pole-plate and capsule containing the concretions are simple and without appendages. The axial funnel is less than one-seventh as long as the stomodæum. The chymiferous canals are of very fine caliber.

The 4 adradial vessels to the meridional subtentacular canals join the latter half-way between the auricles and the aboral apex of the body, thus at the middle of the rows of combs. On the other hand, the 4 adradial vessels to the meridional subventral canals join the latter at the upper ends of the subventral rows of combs. The meridional subventral vessels wind very complexly in the oral lobes, no two individuals being alike in this respect, and, indeed, the canal in one half of the same lobe pursues a course which is not the exact reflection of its meandering curves in the other half 
There are numerous excretory pores along the courses of the meridional vessels (fig. 59, plate II). These alternate with and open between the combs of cilia, and also open along the lines of the 4 meridional subventral canals over the oral lobes below the oral ends of the rows of combs. These pores contain a brilliant rosin-red oily substance which is cast out if the animal be handled roughly or be suddenly disturbed, forming a fluorescent-looking, rosin-red cloud in the water surrounding the ctenophore. When maintained in an aquarium the animal soon loses all of this red pigment and becomes quite transparent and inconspicuous, but in nature its 8 long rows of brilliant red dots render it most beautiful and conspicuous. We can only conjecture that this red substance is of an excretory nature and may possibly serve as a means of protection.

The lateral branches of the 2 paragastric canals are bordered by a row of tentacles, all of which are simple and short, except the median tentacle, which has many short, simple side branches.

The muscular system in the oral lobes is well developed and the lobes commonly overlap. This ctenophore moves wholly by means of its ciliated combs. It is extremely soft in texture and a strong current in the water suffices to tear its tissues. Indeed, I have seen it only when the ocean has been unrippled for a day or more, after which it may be found swimming near the surface at sunrise. A slight ripple causes it to sink out of sight. It was fairly common during May, I906, at Tortugas, Florida, but all of them were found more than 3 miles from land, and apparently it is a creature of the deep and open sea.

Eurhamphea appears to be very rare in the Mediterranean. Gegenbaur found only two specimens, both in a single day in February at Messina, and Chun found it only once in March, I875, during the course of his five years' study of Mediterranean ctenophoræ at Naples. At Tortugas it is rare and occasional, but seems to occur in swarms when found. I have not seen it later in the year than May. Fol describes and figures it from the Canary Islands.

Jonescu gives the latest description and figures of this ctenophore, having found it at Naples in March, I907.

According to Fol, I869, the development is similar to that of other Lobatæ, the larva passing through a Mertensia stage. 


\section{Order CESTIDE Gegenbaur, 1856.}

Callianirida, Eschscholtz, I 829 , Syst. der Acal., p. 2 I.

Cestoidece, Lesson, I843, Hist. Zooph. Acal., p. 68.

Cestidc, Gegenbaur, I 856, Archiv für Naturgesch., Jahrg. 22, p. I 96.

Taeniate, Agassiz, L., I 860 ; Cont. Nat. Hist. U. S., vol. 3, p. 292.

Cestide, Fol, 1869 , Beitrag Entwick. einigen Rippenquallen, p. 6.

Cestide, Chun, I880, Ctenophoren des Golfes von Neapel, p. 300.-VAnhöffen, rgo6, Nordisches Plankton, Ctenophoren, XI, p. 6.

\section{CHARACTERS OF THE ORDER.}

Ribbon-shaped ctenophoræ in which the tentacular axis is mark edly compressed and the lobular axis correspondingly extended. The 4 subtentacular rows of combs are rudimentary and the 4 subventral rows greatly extended. The axial tentacles have basal-sheaths.

Thus in the Cestidæ we find an extraordinary development of the lateral compression seen in lesser degree in the Lobatæ. The funnelaxis is thus reduced and the stomodæal axis greatly extended. This causes the subtentacular rows of combs to be rudimentary while the subventral rows are correspondingly lengthened. The sheaths of the median tentacles recall the conditions seen in the Cydippidæ, and indeed the larvæ of the Cestidæ when hatched from the eggs are Mertensia-like in appearance with the tentacular axis longer than the sagittal, this being the reverse of the condition which pertains in the adult.

There are two genera, Cestum and Folia. In Cestum the narrow, aboral edge of the animal is arched and the 4 subtentacular meridional canals extend upward from their points of origin and are provided each with a very short tract of cilia. They then bend downwards and finally outwards along the middle of the sides to the ends of the body, where they join the 4 meridional subventral canals. In the genus Folia the aboral narrow edge is flat and the 4 subtentacular meridional canals do not arch upward, but extend straight outward to the ends of the sides of the body.

The oral branches of each paragastric canal fuse with the meridional vessels of their own side only, and thus the peripheral canal-system of each broad side of the body is separated from that of the other side; there being no circum-oral canal such as is seen in the Lobatæ.

Species of Cestum are found in all of the warm oceans. Folia is represented by $F$. parallela of the Mediterranean and tropical Atlantic.

Genus CESTUM Lesueur, I8I3.

Cestum, Lesueur, I8I3, Nouv. Bull. des Sci., tome 3, p. 281.-Eschscholtz, I829, Syst. der Akalephen, p. 23.-Mertens, I833, Mém. Acad. Sci. St. Pétersbourg, sér. 6, tome 2, p. 492.-Milne-EdwaRd, I857, Annal. des Sci. Naturelles, Zool., sér. 4, tome 7, p. 291.-Fol, 1869, Anatomie und Entwick. der Rippenquallen, p. 8.-Bigelow, igo4, Bull. Museum Comp. Zool. at Harvard College, vol. 39, p. 267.

Cestus, Chun, r880, Ctenophoren des Golfes von Neapel, p. 301.-VANHörfen, I 906, Nordisches Plankton, Ctenophoren, XI, p. 6.

GENERIC CHARACTERS.

Cestidæ in which the great extension of the sides in the stomodæal axis and the marked compression of the body in the tentacular axis cause the animal to assume the shape of a long, flat ribbon. The 4 inter- 
radial canals arise directly from the funnel. The 4 meridional subventral vessels are very long and extend around the aboral side of the narrow edge of the body. The 4 meridional subtentacular canals each give rise to a short tract of cilia and then bend downward and outward along the middle of the sides of the animal and join with the meridional subventral canals and the oral forks of the paragastric canals at the extremities of the long sides of the animal. Each of the 2 median tentacles arises from a deep sheath. The sexual products are developed only in the long subventral canals. The larva passes through a Mertensia-like condition in which the tentacular axis is longer than the stomodæal axis.

Species of Cestum are found in all the warmer oceans. The type species is Cestum veneris Lesueur, of the Mediterranean and tropical Atlantic. "Cestum amphitritis" of Mertens, I833, appears to be the same species from the tropical Pacific.

Cestum veneris Lesueur. (Figs. 60 and 6r, plate $\mathrm{I2.)}$

Cestum veneris, Lesueur, ז8 8 , Nouv. Bulletin des Sciences de la Sociét. Phil., tome 3, p. 281, planche 5, fig. 1.-Lesson, 1836, Annales des Sci. Nat., sér. 2, tome 5, p. 245.-FoL, I869, Beitrag Anat. Entwick. Rippenquallen, Berlin, p. 8, Tafln. $2-4$.

Cestus veneris, Chun, r880, Ctenophoren des Golfes von Neapel, pp. 53, 135, I 52, I8I, 30I, Taf. II-I3 (full list of literature).-AllmaN, 188I, Journal Linnean Soc., London, vol. I6, p. Iо6.-Crun, I 898, Ctenophoren des Plankton-Exped., p. 20.-Graeffe, 1884 , Arbeit. Zool. Inst. Wien, Bd. 5, p. 362.-Wagner, N., I 885, Die Wirbellosen des Weissen Meeres, p. 54, -Römer, I 903 , Fauna Arctica, Ctenophoren, Bd. 3, p. 85.-VanhöfFEN r 906, Nordisches-Plankton, Ctenophoren, I I, p. 6, Fign. I 4, I 5.-SAMASSA, I892, Archiv für mikroskop. Anatomie, Bd. 40, pp. I69, 218 (histology).-Moser, I908, Abhand1. Akad. München, Suppl. Bd. I, Abhand1. 4, p. I 2.

Cestum amphitrites, Mertens, I 833, Mém. Acad. Sci. St. Pétersbourg, Sci. Math Phys. et Nat., sér. 6, tome 2, p. 492 , Taf. I (tropical Pacific).

Cestus pectenalis, Bigelow, I904, Bull. Museum Comp. Zool. at Harvard College, vol. 39 , p. 267 , plate 8 , fig. 30 (Indian Ocean).

The animal is flat and ribbon-shaped, being about $80 \mathrm{~mm}$. high and sometimes over $1,500 \mathrm{~mm}$. wide, although specimens over $800 \mathrm{~mm}$. in width are not common. The body is strongly compressed in the tentacular diameter. The apical sense-organ is a simple capsule containing a cluster of concretions, and is slightly depressed beneath the general level of the body surface. The long, narrow aboral side of the animal is arched and bears small, wart-like protuberances. The ventral, tentacle-bearing edge is much narrower than the aboral edge, and the sides bulge slightly outward so that the animal is widest midway between mouth and apex. The subtentacular rows of combs are represented by 4 short tracts close to the sides of the sense-organ. Beyond these there is a short, free interval, and then commence the 4 long subventral rows of combs which extend along the sides of the arched aboral edge of the animal. Simple tentacles, closely set in a double row, extend along the sides of the oral edge of the animal, following the courses of the oral branches of the paragastric canals.

The stomodæum is cruciform in cross-section, being slightly outfolded in the tentacular (funnel) axis, although wider in the sagittal axis. The funnel is about one-third to one-fourth as long as the height of the animal, becoming relatively shorter as the animal increases in size. The 4 slender, interradial canals arise from the funnel, as do also, 


\section{Plate i I}

Eurhamphca vexilligera.

FIg. 57. Enlarged view of auricular side of animal. Tortugas. Florida, May I 5, I906.

FIG. 58. Specimen about I.75 times natural size. Side view facing oral lobes.

FIG. 59. Part of one of the combs of cilia, showing excretion pores between combs and papillate surface of genital organs.

Drawn from life, by the author. 


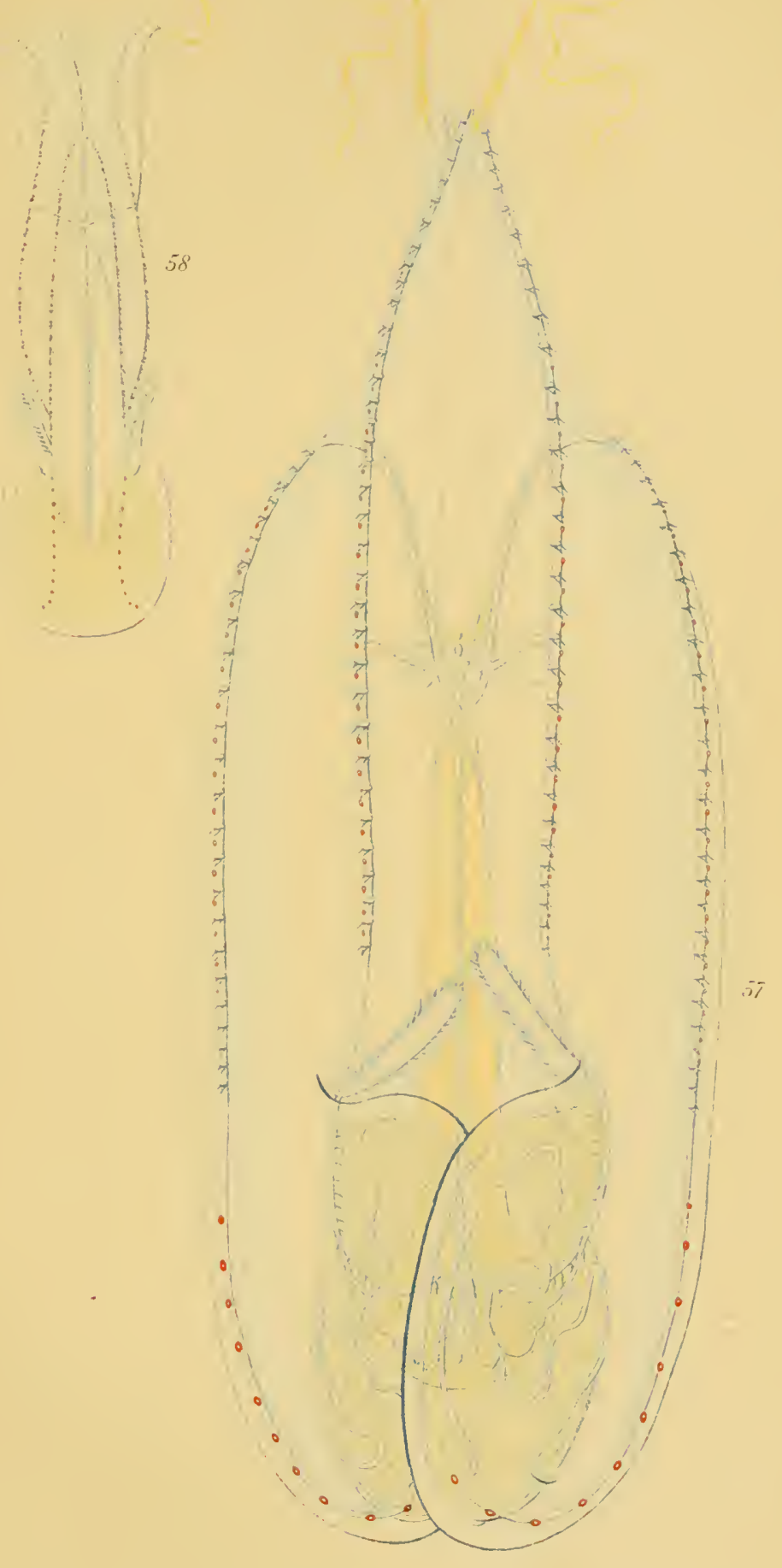

yाin

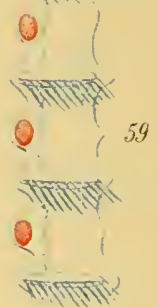



at a lower level, the 2 paragastric and 2 tentacular vessels. All of these canals are of slender caliber.

The 4 interradial vessels ( $i$, fig. $6 \mathrm{I}$, plate I2) fork near their aboral ends, and give rise to 8 adradial vessels ( $a d$, fig. 6 I, plate I 2$)$. The adradial canals leading to the meridional subventral vessels are relatively long, but those leading to the meridional subtentacular vessels are very short. The subtentacular vessels, st, give rise to 4 short rows of combs and also extend outward and downward (oral-ward) beyond their points of origin, and then bend inward and finally outward along the middle of the broad sides of the body and at last join with the 4 meridional subventral canals at the middle of the tips of the ribbonlike body. The oral forks of the paragastric canals also fuse with the meridional canals at this point, and in their course along the almost knife-edged oral side of the body one finds numerous, simple tentacles. The oral forks of one side of the body do not connect with those of the opposite side, and there is no ring-canal around the mouth. There are neither tentacles nor combs upon the narrow, lateral ends of the body. The 2 rudimentary, axial tentacles are each set within a deep sheath in the side of the body close to the side of the paragastric canals.

The sexual products are developed throughout the entire lengths of the 4 meridional subventral canals under the combs of cilia.

The young animal is transparent, but when old it often becomes violet with a beautiful greenish-blue or ultra-marine fluorescence (see Chun, I8So, Ctenophoren des Golfes von Neapel, p. I 52).

The embryonic development has been well described by Chun, I880, pp. I35-I4I. The larva passes through a Mertensia-like stage wherein the tentacular diameter is longer than the stomodæal axis, although as growth proceeds the stomodæal axis becomes so enormously extended that the body is reduced to the shape of a flat ribbon. While in the Mertensia stage there are about 4 ciliated plates on each of the meridional subventral and I ciliated plate on each meridional subtentacular canal. The meridional canals and the paragastric canals at first end blindly, but their free ends extend outward and downward and finally fuse with the oral forks of the paragastric vessels. The larva is strikingly like the Cydippidæ and shows the evident derivation of Cestum from this order, but the general plan of the canal-system resembles that of the immature Beroïd, in the separation of the peripheral canal systems of the two sides of the body although in the mature Beroidæ a circum-oral canal develops in some species, and all of the meridional vessels become connected by a network of fused lateral branches.

Cestum veneris is abundant in the Mediterranean and is also found in the tropical Atlantic. At Tortugas, Florida, it is not often met with, but can not be called rare. The so-called Cestum amphitrites Mertens, of the tropical Pacific, appears to be identical with the Atlantic and Mediterranean C. veneris, and Bigelow, 1904, appears to have described this form from the Maldive Islands, Indian Ocean, under the name Cestum pectenalis. Wagner, 1885 , records the capture of Cestum veneris in the White Sea and this is the most northerly locality from which this Ctenophore has been reported. It was probably swept northward along the Norwegian coast in the Gulf Stream drift. 
In the Pacific Cestum the lateral ends of the long body bear yellow pigment, according to the figure by Mertens, 1833 , and the description and figure by Bigelow, 1904. This has not been observed in the Atlantic or Mediterranean Cestum, but it occurs in the closely allied Folia from Tortugas. The coloration may be due to the presence of commensal plant-cells.

Genus FOLIA (nom. nov.)

Vexillum, preoccupied by Bolten for Mollusca in 1798 .

Vexillum, FoL, I 869 , Anat. und Entwick. der Rippenquallen, Berlin, p. 6.-CHUN, I 880, Ctenophoren des Golfes von Neapel, pp. 300, 302 .

\section{GENERIC CHARACTERS.}

Cestide with body elongated in the stomodæal axis, as in Cestum, but with the aboral narrow edge flat, not arched, as in Cestum. The 4 subtentacular meridional tubes do not bend outward and inward from their points of origin from the 4 adradial vessels as in Cestum, but proceed straight outward along the middle of the broad sides of the animal.

The type species and only known form is Folia parallela of the Mediterranean and tropical Atlantic.

The genus is closely allied to Cestum, but is at once distinguished by its straight, subtentacular canals, whereas those of Cestum curve where they arise from the axial canal-system.

Unfortunately we can not retain the generic name Vexillum, for it was preoccupied for Mollusca by Bolten, I798, in Catalogus Museum Boltenanum, Pars Secunda, p. I38, and this name is accepted by Hermannsen, 1847 , in Indicis generum malacoz., vol. 2. I therefore propose the name Folia, in honor of Professor Fol, who discovered this ctenophore among the Canary Islands.

Folia parallela. (Figs. 62 to 65 , plates $\mathrm{I}_{3}$ and $\mathrm{I}_{4}$.)

Vexillum parallelum, FoL, I869, Anat. und Entwick. der Rippenquallen, Berlin, p. 6, Taf. 2, Fign. I-5.-CHUN, I880, Ctenophoren des Golfes von Neapel, p. 303, Taf. I1, Fign. 4-6, Taf. I3, Fign. 14-17, 1898, Ctenophoren der Plankton-Expedition, p. 2 r.-Moser, I 908 , Abhandl. Akad. München, Suppl. Bd. I, Abhand1. 4, p. 15.

This species is smaller than Cestum veneris, being only about I $5 \mathrm{~mm}$. high and $50 \mathrm{~mm}$. wide. The aboral edge is nearly flat, not arched as in Cestum. The stomodæum is shorter than in Cestum, being not half as long as the height (oral-aboral axis) of the animal. Above all the 4 subtentacular meridional tubes proceed straight outward along the middle of the broad sides of the animal from their points of origin at the ends of the 4 rudimentary adradial canals to the edge of the outermost sides of the animal, where they join the 4 subventral canals. The separation between the subtentacular and subventral rows of combs is not so wide as in Cestum, being hardly perceptible in some specimens. The tentaclebulb and its sheath are smaller than in Cestum. In the Mediterranean the Folia is colorless, but at Tortugas, Florida, some of the specimens (not all) show faint yellow in the gelatinous substance of the aboral sides of the extended ends of the animal. This yellow color may, however, be due to the presence of commensal plant cells. Fol described this ctenophore from the Canary Islands, and Chun found it in the Medi- 



\section{Plate I2.}

Fig. 6o. Center of a young Cestum veneris, $84 \mathrm{~mm}$. long. Tortugas, Florida, May 25, 1907 .

Fig. 6r. Center of a mature Cestum veneris. Tortugas, Florida, July 4 , r9o7. $a d$, adradial vessels; $f$, funnel; $f t$, axial funnel-tube; $g$, paragastric canals; $i$, interradial canals; mu, muscle fibers; st, subtentacular meridional canals; sto, stomodæum; sv, subventral meridional canals; $t$, tentacular canals; ten, tentacle-bulb; $t$, opening of tentacle-sheath.

Drawn from life, by the author. 


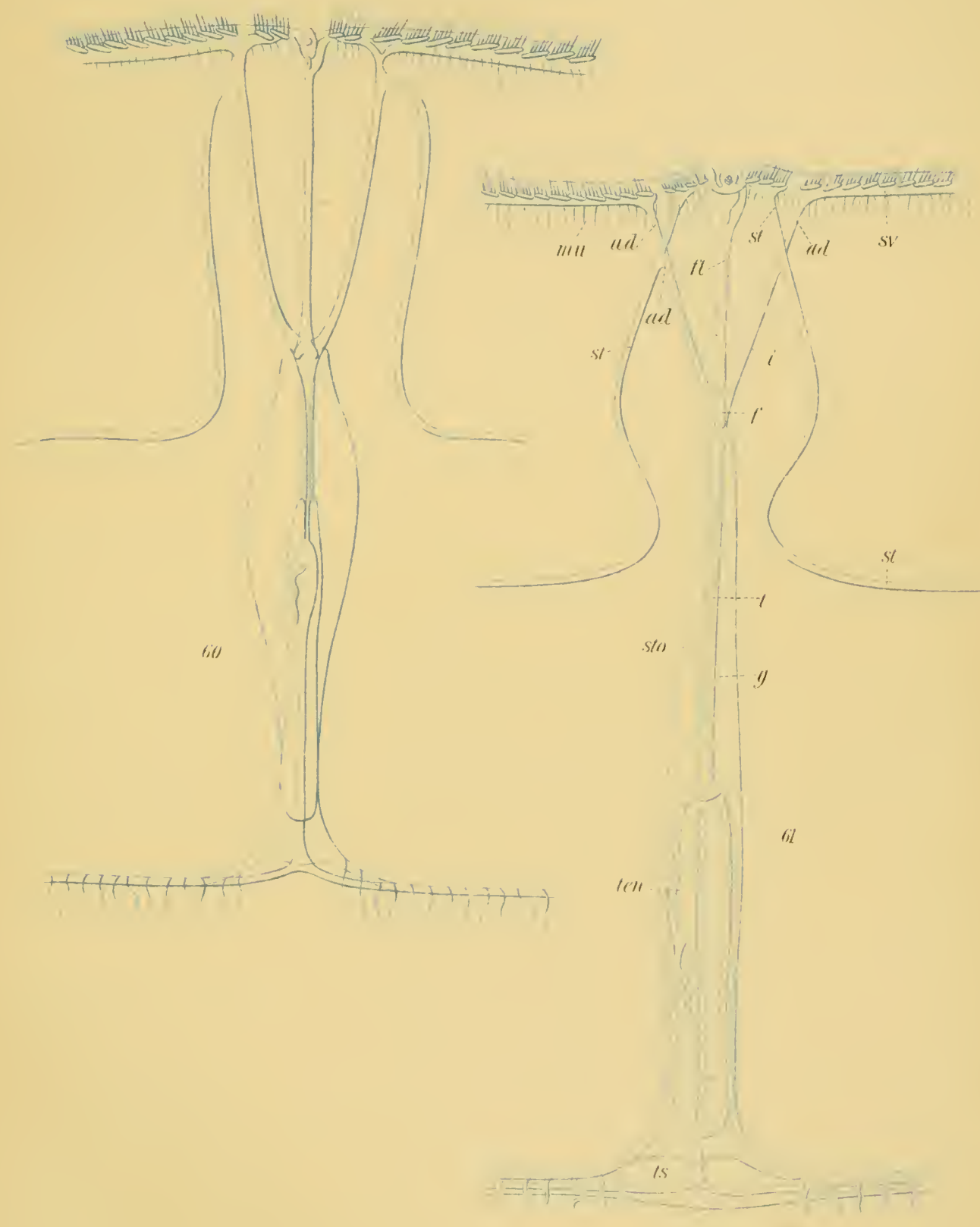



terranean, and it is evidently distributed entirely across the tropical Atlantic, being fairly common at times at Tortugas, Florida.

The animal moves by vermiform contractions, aided by its combs of cilia, and advances with remarkable rapidity by a series of sudden darts with intervals of rest between. I have seen a perfect specimen of this ctenophore which was swimming normally in an aquarium suddenly tear itself into shreds through muscular contraction.

\section{Order BEROÏDAE Eschscholtz, I829.}

Beroidce, Eschscholtz, i 829, Syst. der Acal., p. 35.-Gegenbaur, i 856, Archiv für Naturgesch., Jahrg. 22, p. I92.-Agassiz, A., I 865, North Amer. Acal., p. 35.-CHUN, I880, Ctenophoren des Golfes von Neapel, p. 303.- Moser, 1903, Ctenophoren der Siboga-Exped., p. 19.-VAnnöfFEN, I 906, Nordisches Plankton, Ctenophoren, p. 7.-Römer, I903, Fauna Arctica, Ctenophoren, Bd. 3, p. 81. - BenHAM, I907, Trans. New Zealand Institute, vol. 39, p. I39.

Agassiz regarded the Beroïæ as the simplest of the ctenophoræ and considered that the more complexly organized Lobatæ, Cydippidæ, and Cestidæ were derived from them. They are simple in that they lack tentacles and tentacular canals. The structure of the apical senseorgan and the papillæ of the pole-plate are, however, more complex than in other orders of ctenophoræ. Chun, 1880 (pp. 267, 271), contrary to Agassiz, regards the Beroïdæ as the most highly differentiated of ctenophoræ and considers that they have remotely descended from tentaculate forms, and that they can not be regarded as the ancestral type from which the existing tentaculate ctenophoræ have been derived.

The loss of the tentacles in the Berodiæ may have come about, according to Chun, through the powerful development of the cilia, giving freedom and rapidity of motion, and through the great development of the wide-flaring mouth which enables the animal to obtain food without depending upon tentacles to capture prey. It is remarkable, however, that no trace of tentacles or tentacular vessels appears in the larvæ of Beroïæx, but we must remember that in the genus Ocyropsis of the Lobatæ there are neither tentacles nor tentacular vessels, so that the case of the Beroidæ does not stand alone and need give us no great concern. Moreover, in essential respects the fusions between the oral branches of the paragastric and the meridional canals are similar in Cestidæ and Beroïæe excepting that in the Beroïææ an anastomosing network may connect some or all of the meridional canals one with another.

The lateral diverticula of the meridional and oral branches of the paragastric canals, which are seen only in the Beroidæ, are evidently, phylogenetically speaking, of recent origin, for they appear very late in ontogeny in Beroë.

It is probable that the Beroïæ and Cestidæ are derived from a common stock whose relationship to the Lobatæ was close.

The lateral compression in the funnel-axis is more marked in the Beroidæ than in any other order of ctenophores excepting the Cestidæ.

There are 2 genera, Beroe in which the aboral pole of the animal is dome-like and oval, and Neis Lesson, in which there are 2 prominent lobes on both sides of the apical sense-organ. (See von Lendenfeld, I 885, Zeit. für wissen. Zool., Bd. 41, p. 673.) 


\section{Genus BEROË Browne, I756.}

Beroè, Browne, I 756, Civil and Nat. Hist. Jamaica, p. 384 ; also, edition 2, I $789 .-$ FABricius, 1 780 , Fauna Grönlandica, p. 361.-CHUN, I 880, Ctenophoren des Golfes von Neapel, p. 306.-Agassiz and MAYER, r899, Bull. Museum Comp. Zool. at Harvard College, vol. 32, p. I77.-MOSER, I903, Ctenophoren der Siboga-Exped., p. 20.-BENHAM, I907, Trans. New Zealand Institute, vol. 39, p. I39.-Moser, Igo8, Abhand1. Akad. München, Suppl. Bd. I, Abhand1. 4, p. I 8, I907; Ctenophoren der deutsche Südpolar-Exped., Bd. I I, Zool. 3. p. I 53.-MAAs, I 908, Méduses Exped. Antarctique Française, p. I 5.

Idyia, Fré Minville, I 809 , Nouv. Bull. Soc. Philomat., p. 329.

Beroē, Medea, Pandora, Eschscholtz, I829, Syst. der Acal., pp. 35, 39.

Idya, Cydalisia, Lesson, I843, Hist. Zooph. Acal., p. 67.

Rangia, Idyia, Idyiopsis, AgAssiz, L., I860, Cont. Nat. Hist. U. S., vol. 3, pp. I91, $270,288,296$.

Pandora, Moser, 1908, Abhandl. Akad. München, Suppl. Bd. I, Abhandl. 4, p. 32. 1909; Ctenophoren der deutsche Südpolar-Exped., Bd. I I, Zool. 3, p. I 59.

Pandora, preoccupied for Mollusca by BRUGUIÈRE, I 79 I.

\section{GENERIC CHARACTERS.}

Body miter-shaped, egg-shaped, or conical; extended laterally in the stomodæal axis. Mouth opening wide and ectodermal portion of stomach (stomodæum) voluminous. The polar-plate surrounding the sense-organ at the aboral pole is fringed with a row of branched papillæ. There are neither tentacles nor tentacular vessels. There are ciliated areas upon the walls of the stomodæum near the mouth. The axial funnel-tube which extends upward to the sense-organ, is deeply cleft so that 2 lateral vessels extend upward to the 2 apical excretion-pores on the sides of the pole-plate. 8 meridional vessels and 2 paragastric canals. The meridional vessels lie under the 8 rows of ciliary combs; the 2 paragastric vessels extend down the middle of the broad sides of the animal and branch out in a $\perp$-like manner near the mouth, and fuse with the meridional canals of that side only, but in $B$. ovata the 8 meridional canals may be placed in communication one with another by means of an anastomosing network of side branches, thus establishing a circum oral canal-system. L. Agassiz and Chun state that these anastomosing vessels do not cross the narrow sides of the body, thus leaving the 4 meridional vessels of one broad side separated from those of the other broad side; but I find that while this is true of the young, in mature specimens of $B$. ovata from Tortugas all 8 of the meridional vessels are connected by the network, which extends across the narrow sides of the animal. In B.cucumis, however, the side-branches do not anastomose, so that Agassiz's statement is true for this species only.

The type species is Beroe ovata of the Mediterranean, Atlantic, and Pacific.

In Beroe ovata the side branches from the 2 oral vessels and from the 8 meridional canals are deep-lying and anastomose, fusing to some extent with the 2 paragastric canals. In $B$. cucumis, however, these fusions do not take place and the branches do not anastomose, and the side branches are nearer the surface than in $B$. ovata.

It has been pointed out by Chun that about 45 species of Beroïdæ have been described under 8 generic names, the genera being based mainly on coloration and on external form of the body. Chun, however, came to the conclusion that all of these forms fall into one genus Beroe. The great diversity of opinion among older authors came from a failure 



\section{Plate I3.}

FIg. 62. Folia parallela. Natural size. Tortugas, Florida, May 9, Igo6.

Drawn from life, by the author. 
CTENT,PHSRES OP THE ATLARTT COAST OF NORTH AYEFL A

$r=2=13$

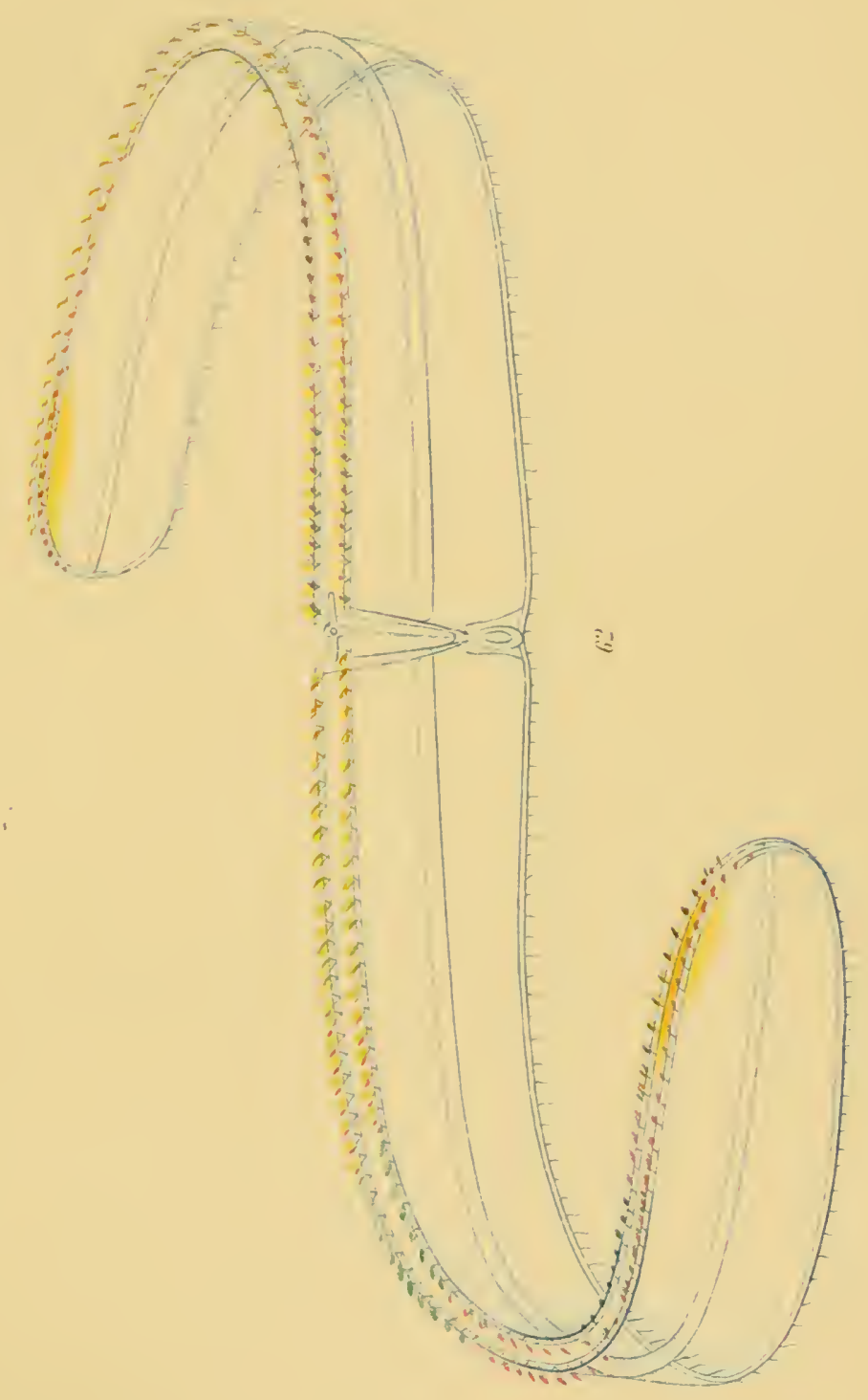

B Meisel in Bo: 

to study the internal structure of the animals. They also placed too much reliance on external shape, which is not only very variable but is also greatly modified by temporary contractions of the muscles. The color in Beroe also changes with age, the very young animals being spotted, afterwards almost transparent, and finally, when mature, more or less diffusely pigmented. Also specimens from cold waters are apt to be pink, while those from the tropics are apt to be dull, translucent, and milky in hue.

$B$.ovata and $B$. forskali are known from the Mediterranean, and they range widely over the tropical Atlantic and Pacific. B.cucumis is found in the Arctic and Antarctic regions and according to Moser also in the Atlantic, Pacific, and Indian oceans, being cosmopolitan in its wide range.

Pandora of Eschscholtz and Moser is, I believe, only a common aberration or growth-stage of Beroe in which the 4 subventral rows of combs are longer than the others. Every large swarm of Beroe ovata along our coast contains some half-grown individuals in this stage, but I have never observed this condition in fully-grown animals. The generic name Pandora is preoccupied and can not be applied to ctenophores.

Kinoshita, I910, Centralblatt Physiol., Bd. 24, p. 726, finds that in Beroe and Lencothea the combs are brought to a stand-still by mechanical stimulation of the oral pole, or of the oral-ward part of a section of the animal; and conversely a stimulation of the aboral pole of a quiet animal sets its cilia into movement, a result which would not follow if we stimulated the oral pole. Stimulation increases the rapidity of the waves that course down the rows of combs.

Beroë ovata Chamisso and Eysenhardt. (Figs. 66, 68 to 75 ; plates I 4 to I6.)

Beroe. Browne, 1756 , The Civil and Natural History of Jamaica, p. 384, Table 43 , fig. 2 ; also, Second edition, 1789.

(?) Beroe albens, ForskĂL, I 775, Descrip. animal, p. I I

Medusa infundibulum, TuRToN, I 806 , Linné's Sys. Nature, vol. 4, Worms, p. I 2 I.

Beroé ovata, $B$. capensis, $B$. punctata, Chamisso et ExsenhaRDT, 182 , Nova Acta Acad. Leop. Car., tome 1o, pp. 360, 36r, Tab. 3 I.

Beroè ovata, B. punctata, Eschschol Tz, I 829 , Syst. der Acalephen, pp. 36, 37. Idya mertensii, Mertens, I $8_{33}$, Mém. Acad. Sci., St. Pétersbourg, Sci. Math. Phys. et Nat., sér. 6, tome 2, p. 536, Taf. I3, Fign. I-4.

Idyiopsis clarkii, Agassiz, L., I 860, Cont. Nat. Hist. U. S., vol. 3, pp. 288. 296; figs. I01, I 02.-Agassiz, A., I 865, North American Acalephæ, p. 39, figs. 63, 64.

Idyiopsis affinis. A gassiz, L., 1860, Cont. Nat. Hist. U. S., vol. 3, pp. $288,296$.

Beroé punctata, McCADY, I 859, Proc. Elliott, Soc. Nat. Hist., Charleston, vol. I, p. 24. Beroé ovata, Chun, I880, Ctenophoren des Golfes von Neapel, p. 308, Taf. I 4, Fign. I, 2 ; I 898, Plankton-Expedition, Ctenophoren, p. 26.

Beroé clarkii, MAYeR, I goo, Bull. Mus. Comp. Zool. at Harvard College, vol. 37, p. 82

Beroé ovata, Allman, 1862, Proc. Royal Soc. Edinburgh, vol. 4, p. 519; also, I 882 , Jour. Linnean Soc. London, vol. 16, p. 89 (development). - KRUKENBERG, I880, Vergleichend. physiolog. Studien zu Tunis, etc., pp. I-22.GRAEFFE, I 884, Arbeit. Zool. Inst. Wien, Bd. 5, p. 362 (occurrence at Trieste).VERTORN, I89I. Pflüger's Archiv. für ges. Physiol., Bd. 50, p. 423, Fign. I-5 (functions of the apicai sense-organ). - NAGEL, 1893, Pflutger's Archiv für Physiol., Bd. 54, p. 165, Fign. I-5 (physiology).-DRIEsch and MORGAN, I 895 . Archiv für Entwickelungsmech., Roux, Bd. 2. p. 204. - ZEIGLER, I898, Archiv für Entwick.-Mech., Bd. 7, p. 34, Fign. I-I2.-RHUMBLER, I 899; Ibid., Bd. 8, p. I87, 28 Fign. (segmentation). - RöMER, I903, Fauna Arctica, Ctenophoren, p. 84 (list of literature).-Moser, I903, Ctenophoren der SibogaExpedition, p. 20 (list of literature).- SAMASSA, 1892 , Archiv für mikroskop. Anat., Bd. 40, p. 207, Taf. 8, 9 (histology).-Lojacono, I 908, Journ. Phys. Path. Gen., Paris, tome Io, p. I001 (the poison of Beroë).-Moser, I908, Abhandl. Akad, München, Suppl. Bd. I, Abhandl. 4, p. 22.

Beroè shakespeari, Benham, I g07, Trans. New Zeal. Institute, vol. 39, p. I39, pl. 7 . 
Body miter-shaped, 70 to I I $5 \mathrm{~mm}$. long. Lateral compression very marked, the broad, lateral diameter being fully 3 times as wide as the narrow diameter. The apical sense-capsule lies near the surface at the bottom of a shallow cleft; it contains a spherical mass of lithocyst cells, and is flanked on two sides by a row of branched papillæ in the form of a figure 8 , the loops of the " 8 " extending around the pole-plate in the plane of the wide, lateral diameter. The 2 excretory pores open on the alternate outer sides of the pole-plate. There are 8 rows of ciliated plates, each row containing 25 to 30 combs of cilia. These extend about threequarters the distance from the apical sense-organ toward the mouth. The mouth is a wide-gaping slit and its cavity is of large dimensions, comprising the greater part of the center of the animal. The entodermal part of the stomach is small. There is no axial funnel-tube, but instead there are 2 lateral tubes which extend upward from the funnel to the 2 halves of the pole-plate. Each of these tubes opens by an excretion pore on alternate opposite sides of the figure " 8 "-shaped pole-plate. The funnel, or entodermal part of the stomach, gives rise to 4 interradial tubes which bifurcate, giving 8 adradial canals, which in turn lead to the 8 meridional vessels that extend down the sides of the body immediately under the 8 rows of ciliary combs. In addition to these meridional tubes there are two lateral paragastric tubes which arise from the funnel and extend down the middle of the broad sides of the animal. The 4 meridional canals of each broad side are placed in communication one with another by means of the oral forks of the paragastric vessels which extend along the broad side of the mouth, but do not fuse with their fellows on the opposite side to form a ring-canal. The 8 meridional canals are, however, placed in communication one with another by means of a loose network of numerous side-branches which anastomose through the gelatinous substance of the animal, forming a wide meshwork. Some of these branches join the 2 lateral, paragastric tubes, although never to the extent observed in $B$. forskali of the tropical Pacific. These fusions occur only in well-grown individuals of Beroe ovata, and distinguish this species from Beroé cucumis of our northern waters, where no anastomosing of the side branches, or fusions with the paragastric vessels has been observed. The young $B$. ovata can not be distinguished from $B$. cucumis. There are numerous small, stellate areas of dark brown and light rosincolored spots upon the 8 meridional vessels and around the mouth. These spots are especially conspicuous in young animals. The network of anastomosing vessels that arises from the meridional canals is of a delicate pink. The gelatinous substance of the mature animal is of a translucent, steely-blue color. In Florida the animal is dull-milky in color, but in the colder northern waters, as in the Chesapeake Bay, it is highly colored and the canals deep pink or reddish-brown.

When $2.5 \mathrm{~mm}$. long the animal is covered with large, stellate pigment spots of a dark brown and rosin-yellow color. The apical sensecapsule is relatively very large and is flanked by 4 branched, ciliated papillæ. The 8 rows of ciliated combs extend only about half the distance from the apical sense-organ toward the mouth. When about $\mathrm{I}_{5}$ to $20 \mathrm{~mm}$. long the animal is quite translucent. The 8 meridional vessels 


\section{Plate I4.}

FIG. 63. Folia parallela. Enlarged view of a young specimen 27 mm. long. Tortugas, Florida, May 29, I906.

Fig. 64. Center of a mature specimen of Folia parallela, about I 50 $\mathrm{mm}$. long. $a d$, adradial canal; $f$, funnel; $f t$, axial funneltube; $i$ interradial canals; st, subtentacular vessel; sto, stomodæum; sv, subventral vessel.

FIG. 65. End of one side of body of specimen whose center is shown in figure 64 . One sees the confluence between the subventral and subtentacular vessels and oral forks of the paragastric canals.

FIg. 66. Beroë ovata. Young Ctenophore, $2 \mathrm{~mm}$. high. Cayo Confites, Northern Coast of Cuba, February, I892.

Drawn from life, by the author. 
Ctenophores of the Atcantig CoAst of North AMERTCA
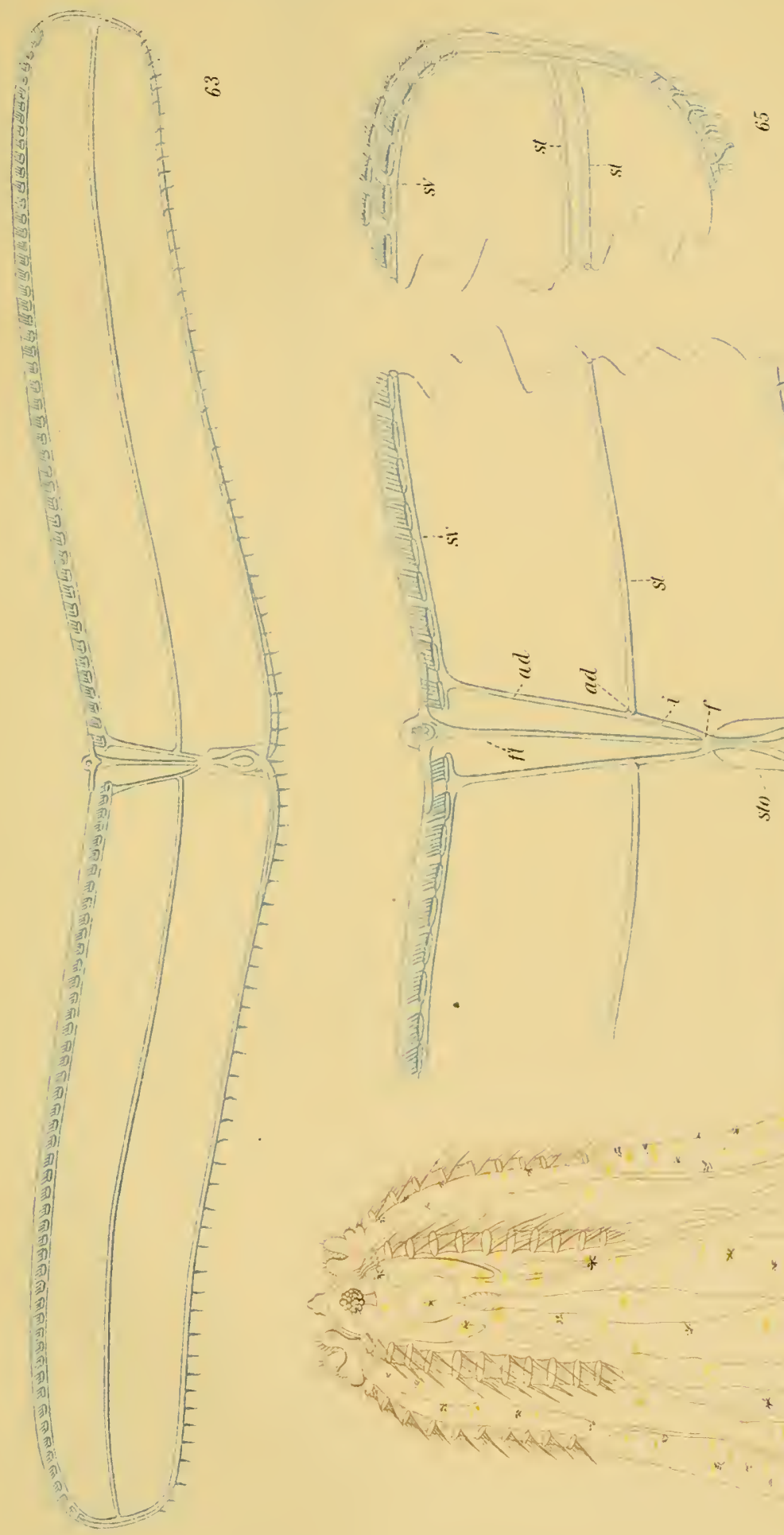

है
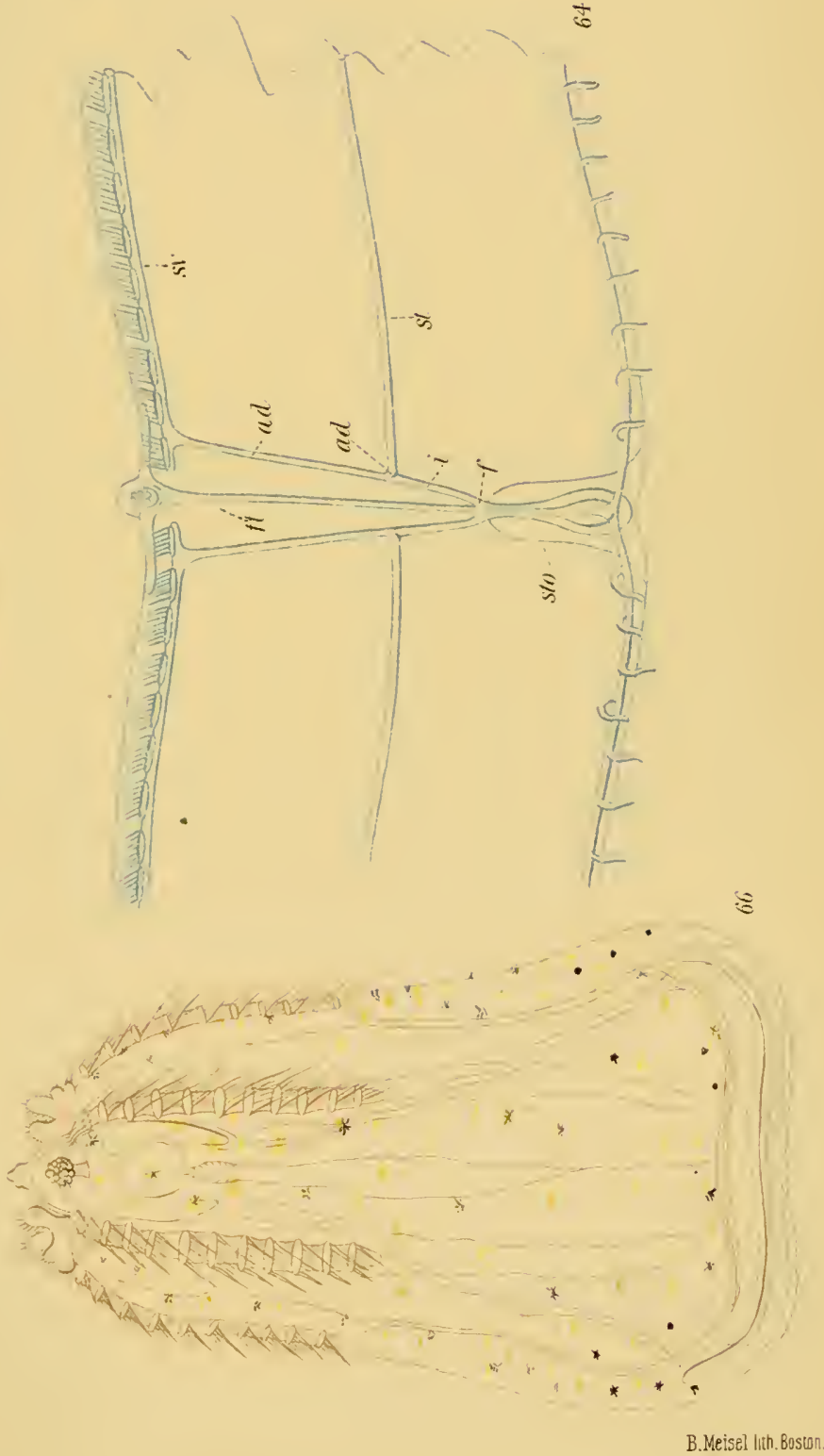




\section{Plate I5.}

Fig. 67. Berö̈ cucumis. $29 \mathrm{~mm}$. long. Eastport, Maine, August I4, I897.

Fig. 68. Berö̈ ovata. Natural size. St. Mary's River, Maryland, November II, 1905 .

FIG. 69. Berö̈ ovata. View looking down upon aboral pole of specimen represented in figure 68 , to show lateral compression of funnel-axis.

Figs. 70 and 7 I. Larval stages of Beroè. Newport, Rhode Island, July, I892, Agassiz Laboratory.

Drawn from life, by the author. 
Clenophores of the AtLantic CoAst of Norti Ameriga

Píate 15.

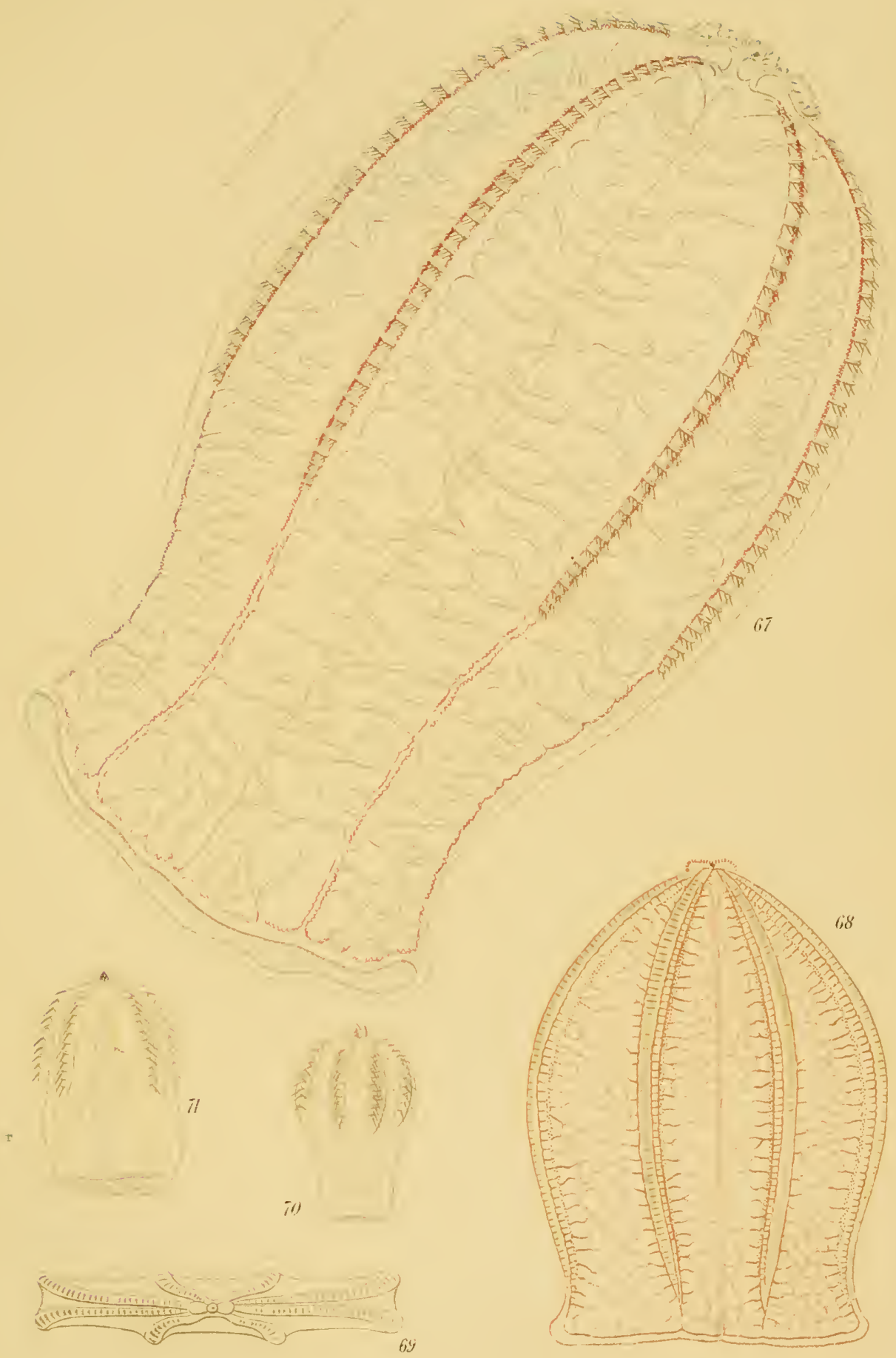

B. Neisel lith. Besian 

begin to give rise to lateral branches, and the papillæ flanking the apical pole-plate have greatly increased in number. The steel-blue color of the gelatinous substance and the pink of the meridional vessels begin to appear at a later stage.

When the young animal from Tortugas, Florida, is $26 \mathrm{~mm}$. long, and $18 \mathrm{~mm}$. wide in the broad, and 7 wide in the narrow axis of the body, the oral forks of each head side of the body remain separate, and do not fuse across the narrow sides. The two broad sides are, however, connected one with another by an anastomosing network from the 4 meridional canals which flank the 2 narrow sides of the body. Hence the network of the narrow sides anastomoses and forms a complete circumoral circuit before any anastomosing is seen on the broad sides of the animal. In this young animal there are as yet no fusions between the network and the 2 paragastric canals. The animal is now decidedly pink in color.

Beroe ovata is abundant among the West Indies and along the coast of the United States as far north as Chesapeake Bay. This species is, I believe, identical with the Mediterranean form, although the Florida specimens are not so intensely pink as the Mediterranean ctenophore.

Beroe shakespeari Benham, from New Zealand, is, I believe, identical with $B$. ovata, for it bears so close a resemblance to the form of $B$. ovata from Florida that were the two found together one could not separate them specifically.

Form, size, and color are practically worthless as specific criteria in the genus Beroe.

Beroe ovata has been the subject of some interesting experimental work. Driesch and Morgan, 1895 , found that if the egg be cut in two at the 2-cell stage, each blastomere gives rise to a half embryo, which, however, has 3 entodermal cells instead of 2 , as one would expect. Only 4 rows of cilia are developed. Hence each blastomere segments almost as if still a part of the whole egg. The same statement is true of the onefourth blastomere obtained by separating the blastomeres of the 4 -cell stage, for each develops into a one-fourth larva with, however, 2 entoderm cells intead of $\mathrm{I}$. It will be recalled that Chun, I $89^{2}$ (Festschrift für Leuckart, pp. 77-108), showed that an isolated blastomere of the 2-cell stage in Bolinopsis produces a half-larva.

Driesch and Morgan cut in two eggs of $B$. ovata which had been fertilized but had not yet segmented, and the part containing the nucleus divided in general like that of an isolated blastomere, giving rise to a partial embryo. Hence the incomplete development is due to the protoplasm, not to the nucleus.

Fischel, I897 (Archiv Entwickelungsmechanik, Roux, Bd. 6, p. Io9, Taf. 6), has continued these studies of Driesch and Morgan. He finds that if we isolate the blastomeres of $B$. ovata in the first, second, and third cleavages, larvæ develop with 4,2 , and I row of combs, respectively. Fischel also found that if we remove some of the blastomeres at any segmentation stage, partial larvæ result, which are the more nearly complete the smaller the removed part. Hence the result is the same whether the nucleus has divided or not, the nucleus manifesting ro 
power to induce a process of regeneration whereby the complete form might be restored. One should consult a review of the work of Driesch and Morgan by Roux, I895 (Roux's Archiv für Entwickelungsmechanik Bd. 2, p. 448), and also by Chun in the same volume (p. 444), who maintains that the missing parts of these partial embryos will in time regenerate. Probably every one who has studied living ctenophores will agree that, while their healing power is remarkable, they appear to have little power to regenerate lost parts.

Verworn, I89r, finds that the concretions of the sense-organ in $B$. ovata are not organs of hearing, but serve to maintain the equilibrium and normal position of the body in the water, and should thus be called statoliths. (See also Engelmann, r887, Zool. Anzeig., Jahrg. Io, p. 439.)

The histology of $B$. ovata is dealt with at length by R. Hertwig, 1880 (Jena. Zeit. für Naturw., Bd. I 4, pp. 3I6-457); and by Samassa, I892 (Archiv mikroskop. Anat., Bd. 40, pp. I59, 207).

Beroë cucumis Fabricius. (Fig. 67 , plate 15 ; fig. 76 , plate 17. )

Beroë cucumis, FABricius, I780, Fauna Grönlandica, No. 353, p. 36r.-EschScholTz, I829, Syst. der Acalephen, p. 36.-SARS, M., I 835 , Beskriv. og. Jagttageker., p. 30, Tab. 6, Fign. I 5a-d.-Morch, I 857 , Beskriv. af. Grönland., p. 98.-VANHöFFEN, I895, Bibliotheca Zoologica, Heft 20, Lfg. I, pp. I6. 20, 2r.-Chun, I 898, Ctenophoren der Plankton Expedition, p. 26.-Römer, r903, Fauna Arctica, Ctenophoren, Bd. 3, p. $8 \mathrm{I}$ (full list of literature).Moser, I903, Ctenophoren der Siboga-Expedition, p. 2 I.-VANHÖFFEN, I906, Nordisches Plankton, Ctenophoren, I I, p. 7, Fign. I6, I 7.-Browne, I905, Proc. Royal Soc. Edinburgh, p. 785-Moser, I 908 , Abhand1. Akad., München, Supp1. Bd. I, Abhand1. 4, p. 23 ; also: Zool. Anzeiger, Bd. 33, p. 756, 1908, Revue Suisse de Zool., tome I6, p. Io (from Amboina); also, rgog, Ctenophoren der deutsch. Süd polar-Exped., Bd. I I, Zool. 3, pp. I 54, I67, I89.

Idya cucumis, I. borealis, Medea fulgens, $M$. arctica, Lesson, I843, Hist. Zooph. Acal., pp. I33, I34, I36.

Idyia roseola, AgAssiz, L., I 860 , Cont. Nat. Hist. U. S., vol. 3, pp. 270 , 296, plates I, 2.-PACKARD, A. S., r863, Canadian Nat. and Geol., vol. 8.-Agassiz, A., I 865, North Amer. Acal., p. 36, figs. 52-62; I874, Mem. American Acad., vol. Io, No. 3 , p. 362 , plates I, 2 ; plate 3 , figs. I-24.-FewKes, r 884 , Mem. Mus. Comp. Źool. at Harvard College, vol. 9, No. 3 , figs. I-7, ro-r 3, 46, 48-50, pl. IX.

Beroë roseola, LeIdy, I89o, Proc. Acad. Nat. Sci. Philadelphia, p. 34 r.

This species attains a length of 60 to $100 \mathrm{~mm}$. It is miter-shaped and the lateral compression is very marked, the broad lateral diameter being fully twice the width of the narrow. The 8 rows of cilia extend about three-quarters the distance from the apical sense-organ to the mouth and each is composed of about roo combs. It is distinguished from Beroe ovata by the fact that the peripheral network does not anastomose and that none of these vessels join the two lateral paragastric canals. There is no ring-canal around the mouth, and the peripheral canal systems of the two broad sides are separated one from another. The intense pink color of the stellate pigment-cells of the meridional vessels and of the circumoral canal is also deeper than in $B$. ovata.

This species is abundant along the coast of New England and attains a very large size in Halifax Harbor, Nova Scotia, in September. It extends along the coast of Greenland, and is common in the Labrador current. It is circumpolar in distribution, is abundant in the North Sea and off the coast of Scotland, and is identical with "Idyia cyathina" 

Plate I6.

Beroè ovata.

Fig. 72. Immature, $30 \mathrm{~mm}$. high, Willoughby Harbor, Hampton Roads, Virginia, October 31, 1904. Lateral diverticula from the meridional vessels close to outer surface; they occasionally anastomose but do not join with paragastric vessels. Yellow color apparently due to parasitic plant cells.

Fig. 73. Mature, I.5 times natural size. Key West, Florida, June 7 , I897.

FIG. 74. Young stage, showing an aberration quite often observed in the young wherein the subtentacular rows of combs are shorter than the subventral. Charleston Harbor, South Carolina, September 7, I897.

FIG. 75. Aboral pole of the ctenophore shown in figure $74 . \mathrm{ad}$, adradial canal; $f$, funnel; $f s$, the two lateral funnel-tubes; $g$, paragastric vessel; $i$, interradial canal; st, subtentacular canal and row of combs; sv, subventral canal. 


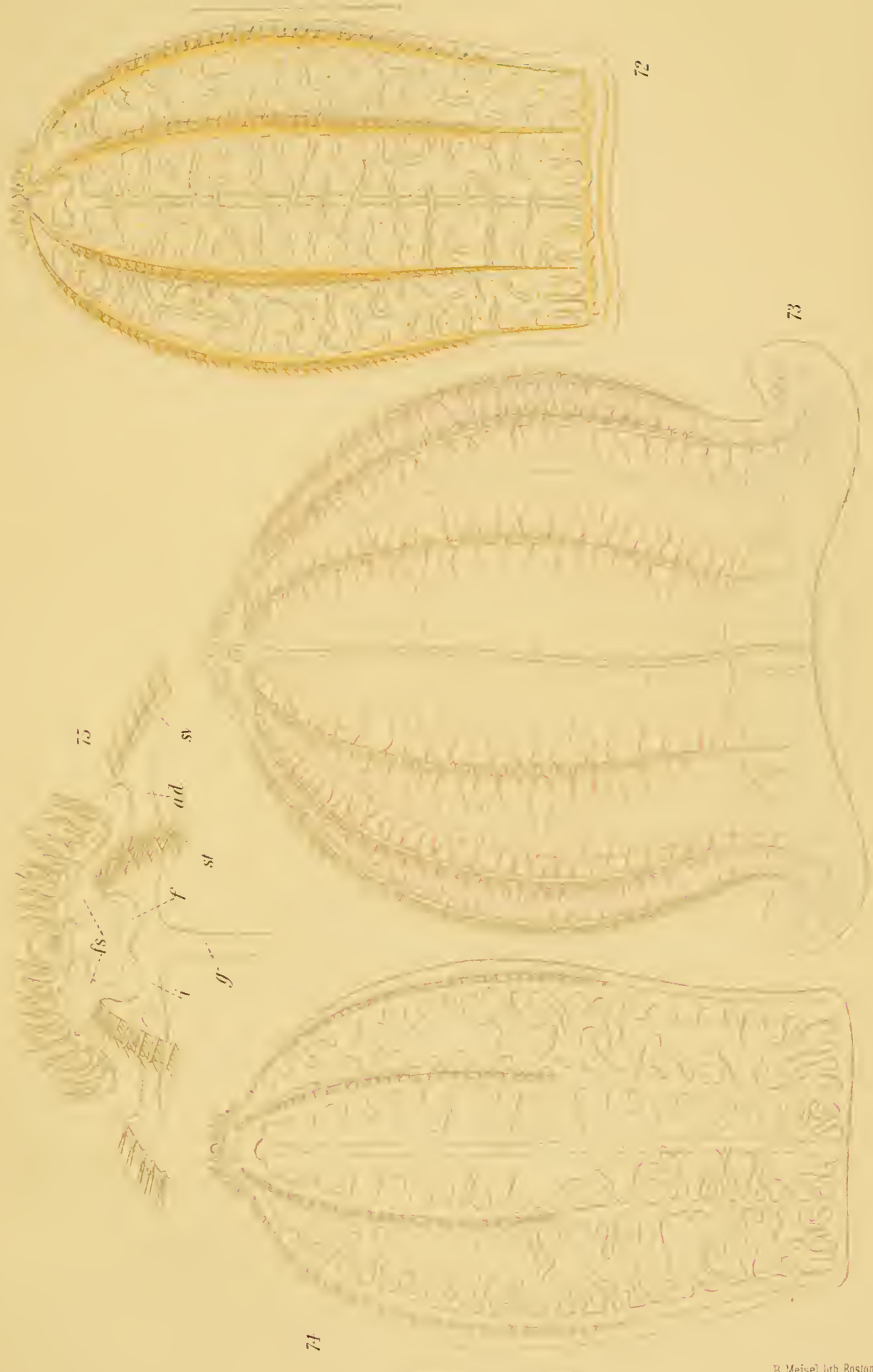



A. Agassiz, from the Pacific coast of North America. Moser, I 908, I 909, records it from the eastern coast of Japan and also from the Antarctic, Pacific, and Indian oceans.

In September, I9I0, I visited Newfoundland in order to examine a sufficiently large number of $B$. cucumis to be assured that it is actually specifically distinct from $B$. ovata. No differences can be detected in the immature individuals of both species. When mature, however, some of the side branches from the meridional vessels join with the paragastric

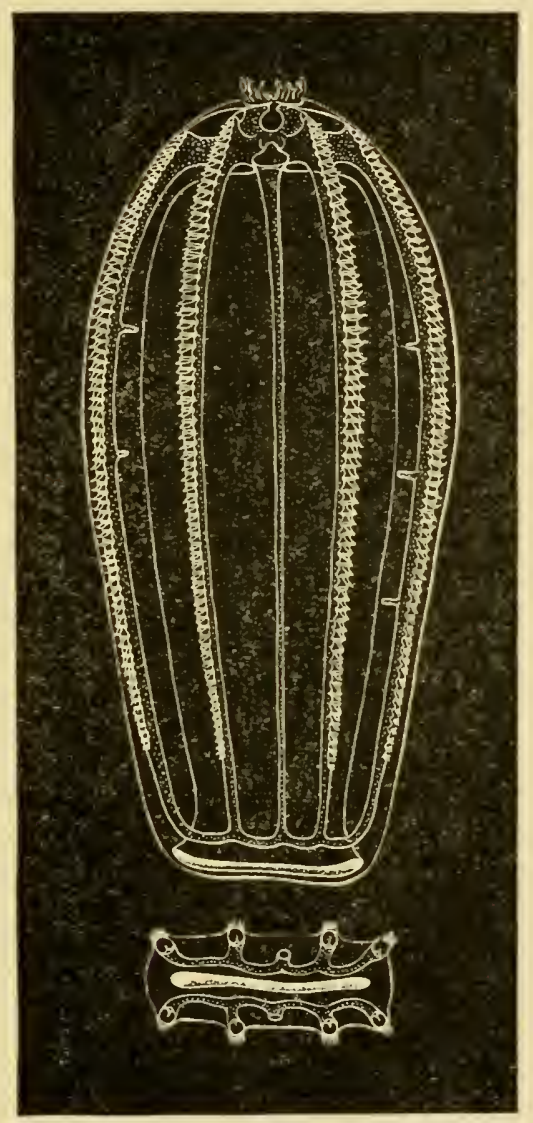

Fig. 12.-Young Beroe cucumis I9 $\mathrm{mm}$. long. From life by the author. Halifax, Nova Scotia, September 27 , r9ro. Peripheral canal-systems of two broad sides are separated one from the other, and there is no ring-canal around mouth. The canal-system is in a stage characteristic of the adult Cestide.

canals in $B$. ovata, but this does not occur in $B$. cucumis. Moreover the side-branches anastomose in $B$. ovata, but in $B$. cucumis they remain separate one from another (see fig. 76 , plate I7.) In $B$. forskali of the Mediterranean, Pacific, and Antarctic oceans, the fusions between the side branches and the paragastric canals are more frequent than in $B$. ovata, but I am not sure that the difference is actually a specific one, for it may be of an intergrading character. 
Moser, I903 (Ctenophoren der Siboga-Expedition, pp. 23, 24), has described and figured two closely related varieties of Beroë, one of which, $B$. pandora, she believes to be identical with Pandora flemingii Eschscholtz, I829 (Syst. der Acalephen, p. 39, Taf. 2, Fig. 7). In both of these forms the 4 subventral rows of combs are longer than the subtentacular (she reverses the accepted usage of these terms in her description) instead of all 8 rows being of equal length. I doubt whether this is a valid specific distinction, for $I$ have noticed a certain intergrading tendency of young individuals of $B$. ovata to have relatively short subtentacular rows of combs. Such an individual obtained from a swarm of normal $B$. ovata, with all 8 rows of equal length each to each, is shown in fig. 74 , plate 16 . When full grown I believe the 8 rows are always practically equal in length each to each.

The differences between $B$. pandora and $B$. pandorino are of such a character that I doubt their validity, bearing in mind the extreme variation in shape of body exhibited by ctenophores of the genus Beroe . Moser, I908, redescribes this ctenophore from Japan under the name Pandora flemingii (see Abhandl. Akad., München, I908, Suppl. Bd. I, Abhand1. 4, p. 32).

There appear to be but two dominant species of Beroë: B. cucumis of cold water, and $B$. ovata of warm waters. $B$. forskali, $B$. pandora, etc., are probably only varieties of $B$. ovata.

The pink color of the stellate pigment cells of the meridional canals does not appear until the young $B$. cucumis is about $25 \mathrm{~mm}$. long, and after the side branches have grown out from the sides of the meridional vessels. When young the animal is transparent with a faint yellowish tinge to the canal-system. The side branches do not begin to develop until the animal is $\mathrm{I} 9 \mathrm{~mm}$. long. When about $23 \mathrm{~mm}$. long it begins to lose its transparency, and to assume the translucent milky hue of the adult.

The young Beroe cucumis devours Pleurobrachia pileus with avidity.

At Halifax, Nova Scotia, in September when the harbor water ranges from $13^{\circ}$ to $15^{\circ} \mathrm{C}$., B. cucumis is most active if heated to about $\mathrm{r} 8^{\circ} \mathrm{C}$, and dies at a temperature between $27.8^{\circ}$ and $29.8^{\circ} \mathrm{C}$. It would seem therefore that $B$. cucumis could not survive in the surface waters of the tropics. 


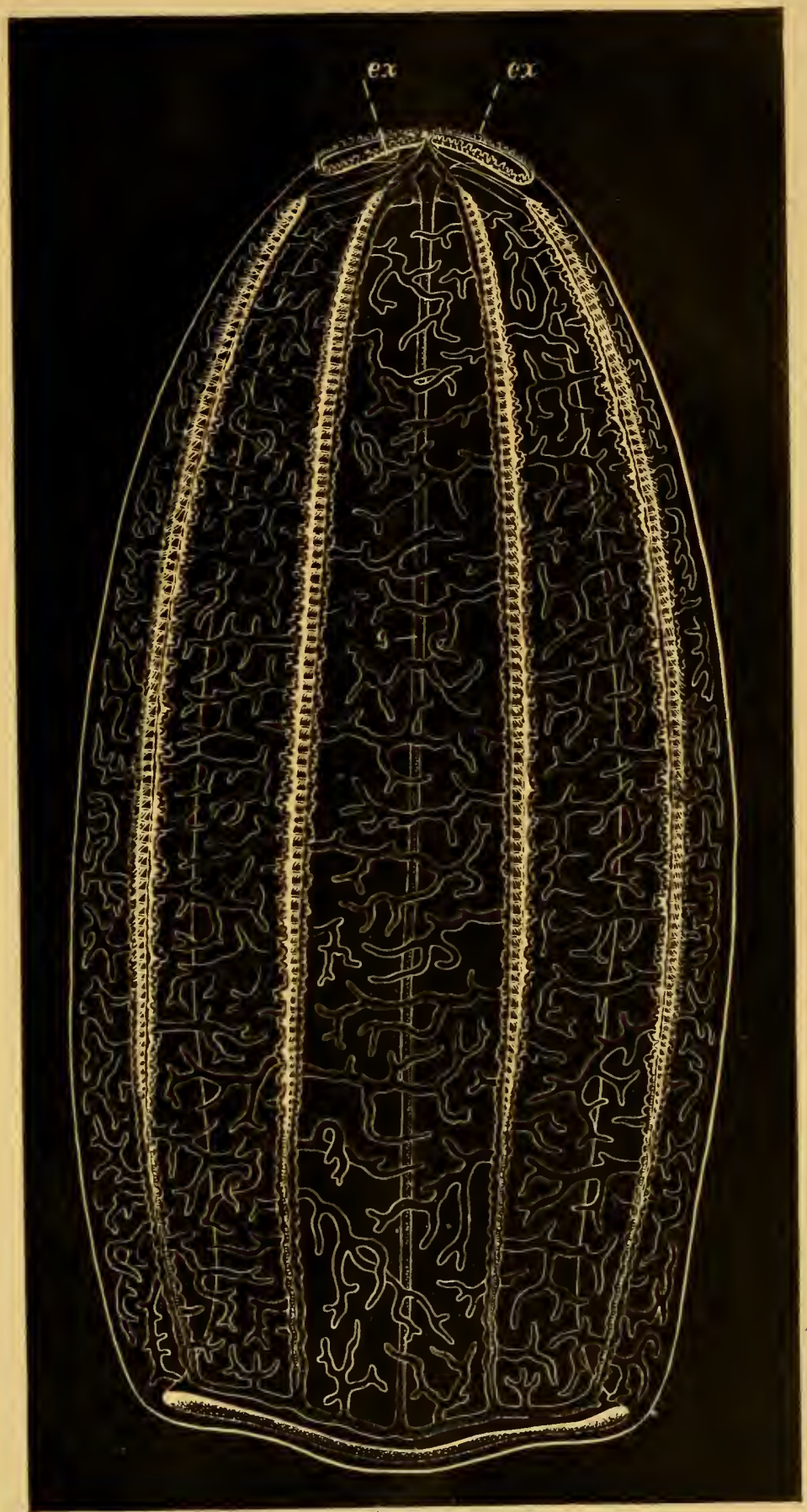

Beröe cucumis.

FIg. 76. Mature specimen, $60 \mathrm{~mm}$. long. Halifax, Nova Scotia, September 28 , 1910. ex, excretory pores: $g$, paragastric canal. The side-branches do not anastomose. Drawn from life by the author. 



\section{Order PLATYCTENIDE.}

These are degenerate forms that have largely or wholly lost their organs of locomotion. They are flat and expanded, the oral-aboral axis being much shortened. They are sessile or creep slowly over sea-weeds. In Coloplana and Ctenoplana the apical sense-organ is present, but in Tjalfiella of Mortensen it appears to be absent. His specimens were, however, preserved in formalin which may have destroyed the concretions. There are two tentacles which are feathered in Ctenoplana and Celoplana, but simple in Tjalfiella.

Mortensen's discovery of cydippe-like young in the brood-sacs of Tjalfiella proves that these forms are simply degenerate, and specialized, not primitive ctenophores. After being set free in the Cydippe stage the young swim about by means of their combs of cilia but soon settle down and lose these organs of locomotion.

Tjalfiella tristoma Mortensen.

Tjalfiella tristoma, Mortensen, I910, Vidensk. Meddel fra den naturh. Foren. i Kobenhavn, p. 249, Fig.

This is the most degenerate of the Platyctenidæ and is found attached by its oral surface to stems of Umbellula lindahlii at depths from 240 to 290 fathoms in Umanak Fjord on the West Coast of Greenland.

The animal is transparent with yellow tentacle-bulbs, and is about Io to $15 \mathrm{~mm}$. long, flat, laterally compressed with the oral surface attached to the Umbellula, and with an erect, funnel-like tower-shaped projection at each end of the body. A slight projection at the middle of the flattened upper side of the animal may represent the degenerated remnant of an apical sense-organ, but there appear to be no lithocysts. A minute pore opens at this place. There are no combs of cilia.

The mouth is at the center of the surface of attachment and gains access to the outer world by means of a median ventral furrow in the tentacular plane. This furrow extends upwards along the sides of the body to the two tentacle bulbs which are set within it at the sides of the funnel-shaped tentacle sheaths. The tentacles have no side branches thus differing from those of Ctenoplana, and Celoplana. The tentacles are provided with colloblasts. There are 4 pairs of knob-like projections on the upper surface of the animal and these mark the position of the sexual organs each consisting of an ovary and a testis which open to the outer world through an ectodermal invagination, as in Ctenoplana.

These genital cavities contain embryos which have ciliated combs and are in the cydippe stage, thus proving that the Platyctenidæ are degenerate and not primitive ctenophores. When about to leave the parent animal a deep furrow develops in the tentacular plane along the oral side of each young ctenophore. The young go through a freeswimming stage before they settle down.

The canal-system of the adult is branched quite complexly.

Mortensen's final paper upon this animal will appear in the Report upon the Ctenophoræ of the Danish Ingolf-Expedition, vol. 5, part 2. 



\section{INDEX.}

Important references are in italics, synonyms and unimportant references are in roman type.

Alcinoē, 26, 34

rosea, 26

vermicularis, 2 I

vermiculata, 26

Anais, 20

Anatomy, 2 to 5 .

\author{
Beroë, 48 \\ albens, 49 \\ capensis, 49 \\ clarkii, 49 \\ cucumis, 52 \\ globigereux, Io \\ octoptera, 9 \\ ovata, 40 \\ pandorino, 54 \\ pileus, ro \\ punctata, 49 \\ roseola, $5^{2}$ \\ shakespeari, 49 \\ Beroida 6, 47 \\ Bolina, 20 \\ alata, 2 I \\ elegans, 24, 34 \\ hydatina, 22, 25 \\ littoralis, 33 \\ norvegica, 2 I \\ septentrionalis, 2 I, 22 \\ Bolinopsis, 20 \\ infundibulum, $2 I$ \\ vitrea, 22
}

Callianiridæ, I 8,42

Calymma, 37 treviriani, 37, 40

Calymnidæ, I 8

Cestida, 6, 42

Cestum, 43 amphitrites, 36,44

pectenalis, 36,44

veneris, 44

Cestus veneris, 44

Chaija, 34

Ciliary movement, nature of, $25,26,30$

Coloplana, 6, 55

Commensal plant cells, 36

Ctenophores feeding upon young cod, 7 ; other ctenophores, 54; young sculpin, 9

Ctenoplana, 6, 55

Cydalisia, 48

Cydippe, 9, 14

cucullus, 8

densa, I5

hormiphora, I 5

ovum, 8

pileus, IO

plumosa, 15

Cydippidce, 5, 8
Deĩopea, 37, 40

Destructive contractions in Folia, 46

Development of: Beroidæ, $47,50,53,54$; Bolinopsis, 22; Cestum, 45; Eurhamphæa, 42 ; Leucothea, 35 ; Mnemiopsis, 28; Ocyropsis, 39; Pleurobrachia, 12 ; Tjalfiella, 55

Enemies of ctenophores, Beroē, 54; scyphomedusæ, 32

Eucharis, 34 multicornis, 35

Eurhamphaa, 40 vexilligera, $40,4 I$

Folia, 46 parallela, 46

Ganesha elegans, 5

Ganeshidæ, 5

Geographical distribution, I, 2

Habits of: Ctenophores, 6; Eurhamphæa, 42 ; Folia, 46; Pleurobranchia, 13 ; Leucothea, 36; Mnemiopsis, 30; Tinerfe, I 7 ; T jalfiella, 55

Heat reactions, 54

Hormiphora, I4

plumosa, 25

spatulata, 14

Idya, 48

borealis, 52

communis, $5^{2}$

mertensii, 49

Idyia, $4^{8}$ cyathina, $\mathbf{5 2}^{2}$ roseola, 52

Idyiopsis, 48

affinis, 49

clarkii, 49

Lesueuria, I0 hyboptera, IQ

vitrea, 19

Leucothea, 34 grandiformis, 36

multicornis, 35,36 ochracea, 35

Lithocysts, structure of, 30

Lobata, 5,18

Medea, 48 arctica, 52

fulgens, 52

Medusa infundibulum, 49

Mertensia, 8 cucullus, 8

ovum, 8

scoresbyi, 8 
Mnemia, 20, 26, 40 schweiggeri, 26

Mnemiidæ, 18

Mnemiopsis, 26 gardeni, 33

leidyi, 26 mccradyi, 31

Movements of muscles, effect of ions upon, 26, 32

Muscular system, physiology of, 26

Neis, 47

Nervous system, histology of, $7,13,52$; physiology of, $7,30,49$

Obsolete generic names, 2

Ocyroē, 37 crystallina, 38

maculata, 40

tachee, 40

Ocyropsis, 37

crystallina, 38

fusca, 39

maculata, 40

Orders of Ctenophoræ, 5, 6

Pandora, 48, 49, 54 flemingii, 54

Parasitic actinian larvæ in Mnemiopsis, 28

Partial larvæ, development of, 5 I

Phosphorescence of Mnemiopsis, 28

Physiology, 7, 25, 26, 30, 31, 32, 46, 49, 5 I, 52 .
Platyctenida, 6,55

Pleurobrachia, 9

bachei, Io, 13

brunnea, 14

pileus, ro

rhododactyla, ro

Pleurobrachiidæ, 8

Poison of Beroë, 49

Eurhamphæa? 42

Rangia, 48

Regeneration, 5

Relationship of: Beroidæ, to Cestidæ, 47; Cydippidæ to Lobatæ, I8; Cydippidæ to Platyctenidæ, 55

Sense of equilibrium, $30,3 I, 52$

Sex cells, ectodermal origin of, I4

Species, list of, I

Stimuli, chemical, 7, 30, 32 electrical, 30

mechanical, 7, 49

Tæniatæ, 42

Tinerfe, Io

beehleri, 17

cyanea, I6

lactea, I7

Tjalfiella tristoma, 55

Ute, $\mathbf{6}$

Vexillum, 46

parallelum, 46

Volvox beroē, 2 I 


